UNIVERSIDADE DE SÃO PAULO

ESCOLA DE COMUNICAÇÕES E ARTES

CAROLINA ITO MESSIAS

UM PANORAMA DA PRODUÇÃO FEMININA DE QUADRINHOS PUBLICADOS NA INTERNET NO BRASIL

SÃO PAULO 
CAROLINA ITO MESSIAS

\section{UM PANORAMA DA PRODUÇÃO FEMININA DE QUADRINHOS PUBLICADOS NA INTERNET NO BRASIL}

\section{Versão Corrigida}

Dissertação apresentada à Escola de Comunicação e Artes da Universidade de São Paulo para obtenção do título de Mestre em Ciência da Informação.

Área de concentração: Apropriação social da informação

Orientadora: Prof. Dr. Giulia Crippa

São Paulo, SP 
Autorizo a reprodução e divulgação total ou parcial deste trabalho, por qualquer meio convencional ou eletrônico, para fins de estudo e pesquisa, desde que citada a fonte.

\author{
Catalogação na Publicação \\ Serviço de Biblioteca e Documentação \\ Escola de Comunicaçöes e Artes da Universidade de Säo Paulo \\ Dados inseridos pelo(a) autor(a)
}

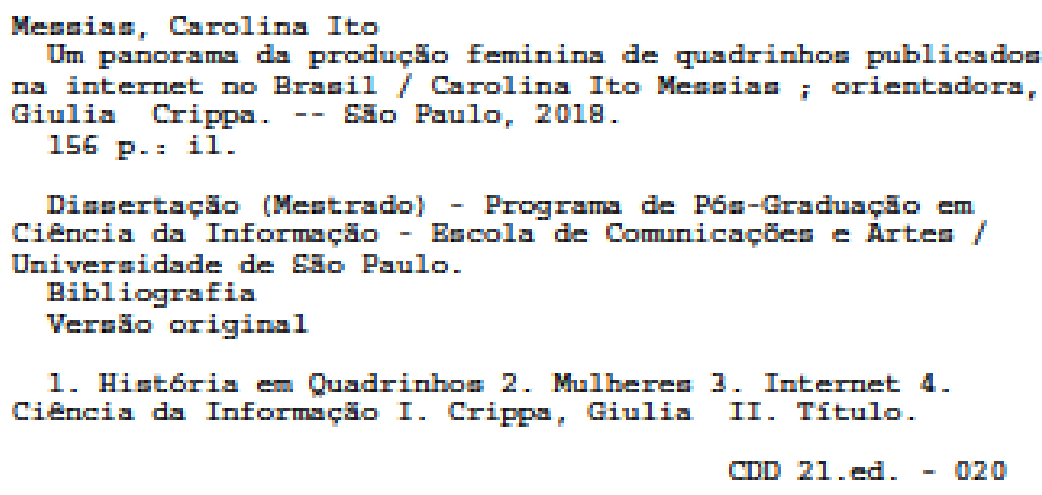


MESSIAS, Carolina Ito. Um panorama da produção feminina de quadrinhos publicados na internet no Brasil. 2018. 156 f. Dissertação (Mestrado em Ciência da Informação) - Escola de Comunicações e Artes, Universidade de São Paulo, São Paulo, 2018.

Aprovado em: 21 de setembro de 2018.

Banca examinadora:

Prof. Dr.: Waldomiro dos Santos Vergueiro

Instituição: Universidade de São Paulo

Prof. Dr ${ }^{\mathrm{a}}$.: Valéria Aparecida Bari

Instituição: Universidade Federal de Sergipe

Prof. Dr ${ }^{\mathrm{a}} .:$ Ediliane de Oliveira Boff

Instituição: FIAM-FAAM Centro Universitário 
Para minha mãe, Erika, que me deu a primeira revista de quadrinhos. 


\section{AGRADECIMENTOS}

Agradeço à Escola de Comunicações e Artes da Universidade de São Paulo e ao Programa de Pós-Graduação em Ciência da Informação, pela oportunidade de desenvolver este trabalho e por oferecer as disciplinas que orientaram.

À Coordenação de Aperfeiçoamento de Pessoal de Nível Superior (CAPES) pelo apoio financeiro para realização desta pesquisa.

À minha orientadora, Prof. ${ }^{a}$ Dr. ${ }^{a}$ Giulia Crippa, por ter acreditado no potencial desta pesquisa, pelas orientações valiosas e pelas conversas que transformaram esta experiência em algo leve e proveitoso, tanto em nível profissional quanto pessoal.

Aos meus pais, Erika e Ricardo, ao meu irmão, João, e à minha tia, Cecília, que sempre me apoiaram e proporcionaram a continuidade dos meus estudos até aqui. À minha querida tia Helena, que possibilitou que eu pudesse participar o processo seletivo da pósgraduação e que nunca desiste de mim.

Aos meus professores da Universidade Estadual Paulista (Unesp), de Bauru, que me motivaram desde a primeira iniciação científica, em especial, os orientadores Danilo Rothberg e Jean Cristtus Portella.

Ao Prof. Dr. Marco Almeida, pelas conversas descontraídas que tanto contribuíram para a minha formação acadêmica e pessoal.

Aos membros da minha banca de qualificação, professores doutores Ediliane Boff e Waldomiro Vergueiro, pelas contribuições valiosas para o desenvolvimento deste estudo.

Ao amigo e sempre companheiro Gustavo Marques, por estar ao meu lado durante todo o processo, nos momentos de angústia e comemoração.

Aos amigos, Ana Biscalchin e Ueliton Alves, que me acolheram com paciência e generosidade.

Às amigas, Amanda Granado, Carolina Baldin, Amanda Tiengo e Isis Rangel, que me fazem ter certeza de que juntas somos mais fortes.

Aos amigos, Artur Rosa e Rafael Giroto, que sempre torceram por mim.

A todas as mulheres quadrinistas que tiveram coragem e força para abrir caminhos para as artistas que surgem a cada dia. 


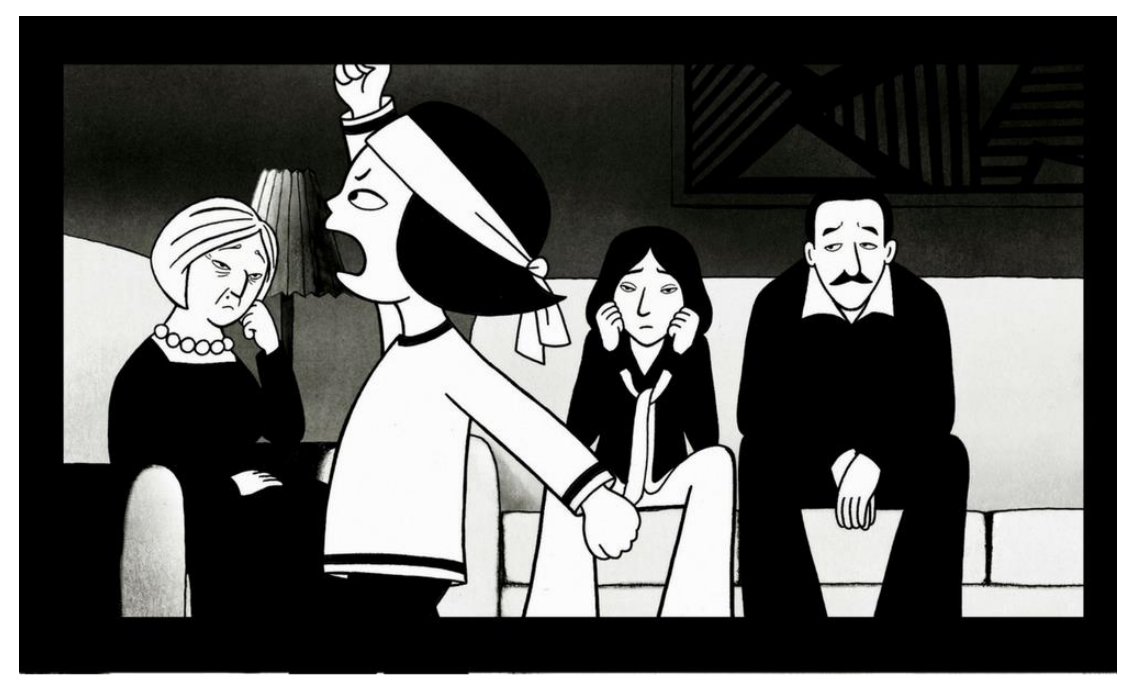

Persépolis, de Marjane Satrapi 


\section{RESUMO}

A pesquisa partiu do levantamento das principais publicações on-line de histórias em quadrinhos feitas por mulheres no Brasil, a partir dos registros contidos nas iniciativas Lady's Comics (website) e Zine XXX (grupo no Facebook), que são plataformas dedicadas à divulgação de HQs femininas. Foram selecionadas oito quadrinistas e suas respectivas obras, considerando histórias contínuas, em que o mesmo enredo se desenvolve à medida que as plataformas on-line são atualizadas pelas autoras, desconsiderando publicações de tiras, cartuns, charges e histórias avulsas. São elas: Bianca Pinheiro (Bear); Brendda Costa Lima (Manual de sobrevivência à vida adulta); Cátia Ana ( $O$ diário de Virgínia); Cris Peter (Quimera); Fernanda Ferreira (Como eu realmente...); Gabriela Masson (Garota Siririca); Germana Viana (Lizzie Bordello e as Piratas do Espaço) e Lita Hayata (Bete vive). Buscou-se identificar os principais temas dessas webcomics selecionadas e situá-las entre obras ficcionais e não ficcionais, realizando uma breve comparação com as publicações de editoras brasileiras. Aplicou-se a metodologia de análise de conteúdo para identificação dos temas; entrevistas estruturadas com as autoras selecionadas, para obter os apontamentos qualitativos da amostra. Como resultados principais, identificamos que todas as webcomics são protagonizadas por personagens femininas, sete são ficcionais e uma é autobiográfica. Após comparação com as publicações de editoras brasileiras, observou-se que as histórias de não ficção (sobretudo, as autobiografias) predominam nos catálogos, quando consideramos as HQs de autoria feminina. Os resultados mostram que na internet existe maior autonomia, permitindo que as quadrinistas escapem aos filtros editoriais na produção de suas HQs. Embora exista maior independência na criação, ter uma publicação on-line não garante credibilidade e projeção às autoras, o que depende de fatores como a presença no circuito de premiações e nos eventos relacionados aos quadrinhos e interesse da mídia especializada.

Palavras-chave: História em Quadrinhos. Mulheres. Cibercultura. Ativismo. 


\begin{abstract}
The research aimed to carry out a survey of the main online comics publications made by women in Brazil, from the records contained in the initiatives Lady's Comics (website) and Zine XXX (Facebook group), which are platforms dedicated to the dissemination of female comics. Eight comic artists and their respective works were selected, considering continuous histories, in which the same plot develops as the online platforms are updated by the authors, disregarding strip publications, cartoons, cartoons and single stories. They are: Bianca Pinheiro (Bear); Brendda Costa Lima (Manual de sobrevivência à vida adulta); Cátia Ana ( $O$ diário de Virgínia); Cris Peter (Quimera); Fernanda Ferreira (Como eu realmente...); Gabriela Masson (Garota Siririca); Germana Viana (Lizzie Bordello e as Piratas do Espaço) and Lita Hayata (Bete Vive). We sought to identify the main themes of the selected comics (which we chose to call "webcomics") and place them between fictional and nonfiction works, making a brief comparison with the publications of Brazilian publishers. The content analysis methodology was applied to identify themes and structured interviews with the selected authors, which allowed qualitative results to be obtained from the sample. As main results, we identified that all webcomics are female characters, seven are fictional and one is autobiographical. After comparison with the publications of Brazilian publishers, it was observed that non-fiction stories (especially autobiographies) predominate in catalogs, when we consider female comics. The results show that on the internet there is more autonomy, allowing comics to escape the editorial filters in the production of their comics. Although there is greater independence in the creation, having an online publication does not guarantee credibility and projection to the authors, which depends on factors such as the presence in the circuit of awards and events related to comics and interest of the specialized media.
\end{abstract}

Keywords: Comics. Women. Ciberculture, Ativism. 


\section{LISTA DE FIGURAS}

Figura 1 - Capa da HQ Miss Fury de June Tarpé Mills (Marvel) ......................................... 20

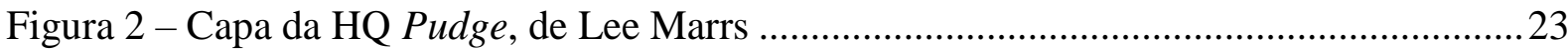

Figura 3 - Auto-retrato de Justin Green na HQ Binky Brown Meets the Holy Virgin Mary.... 24

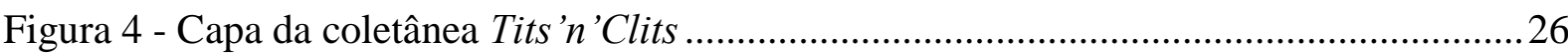

Figura 5 - Capa da coletânea Wimmen's Comix ................................................................ 27

Figura 6 - Página da revista Come Out Comix, com desenho de Mary Wings .......................28

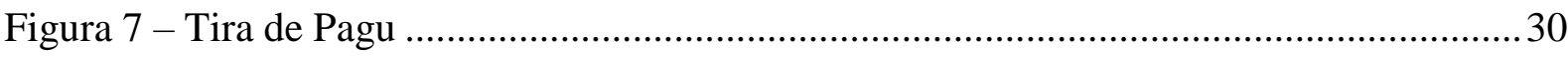

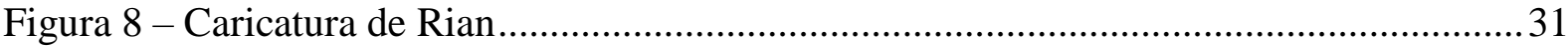

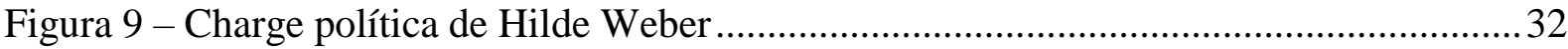

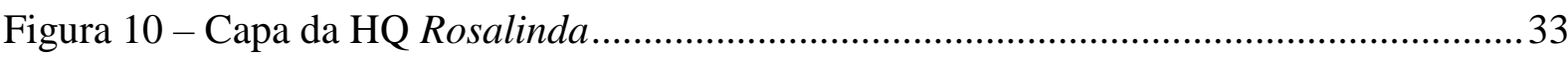

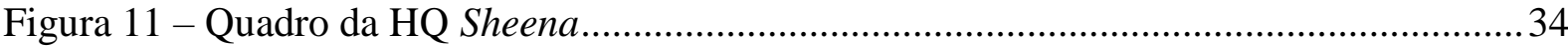

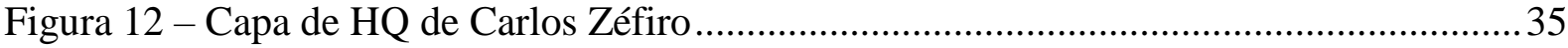

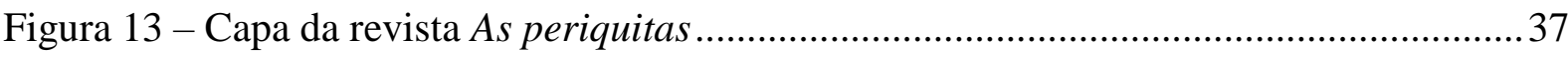

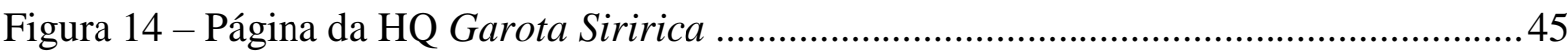

Figura 15 - Página da HQ Lizzie Bordello e as Piratas do Espaço ......................................... 46

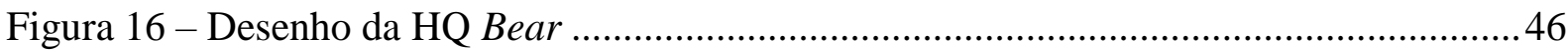

Figura 17 - Cartum de Aimee de Jongh feito para protestar contra os resultados do Festival de

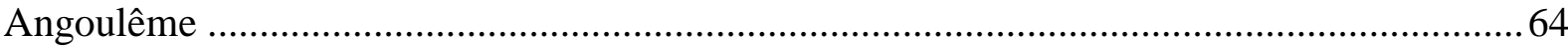

Figura 18 - Fragmento da HQ Bear, de Bianca Pinheiro ....................................................... 76

Figura 19 - Cartaz da HQ Quimera, de Cris Peter, responsável pelo roteiro e colorização .... 77

Figura 20 - Fragmento da HQ Bete Vive, de Lita Hayata ................................................... 78

Figura 21 - Fragmento da HQ Garota Siririca, de Gabriela Masson ..................................... 79

Figura 22 - Fragmento da HQ Como eu realmente..., de Fernanda Ferreira .......................... 80

Figura 23 - Fragmento da HQ Manual de sobrevivência à vida adulta, de Brendda Costa

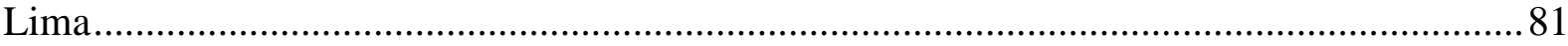

Figura 24 - Cartaz da HQ 0 diário de Virgínia, de Cátia Ana ................................................... 81

Figura 25 - Fragmento da HQ Lizzie Bordello e as Piratas do Espaço, de Germana Viana... 82

Figura 26 - HQ Bear, de Bianca Pinheiro, aborda a amizade entre uma garotinha e um urso.84

Figura 27 - A personagem Bete, criada por Lita Hayata, ................................................. 85

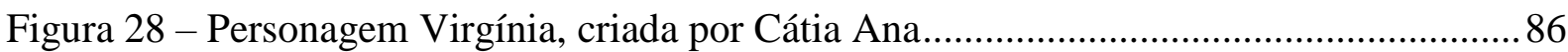

Figura 29 - Personagem de Garota Siririca, HQ de Gabriela Masson, é usuária de maconha 88 


\section{SUMÁRIO}

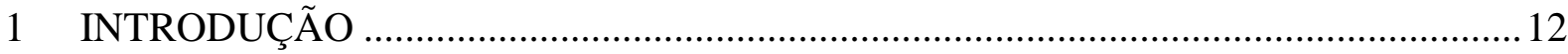

2 ECONOMIA E CIRCULAÇÃO DE QUADRINHOS IMPRESSOS ............................ 18

2.1 O mercado editorial norte-americano e a atuação feminina .......................................... 19

2.2 Formação do mercado editorial brasileiro e atuação feminina.......................................29

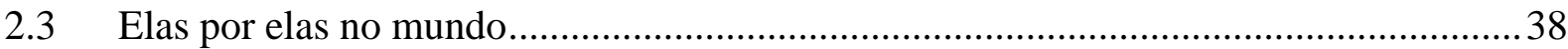

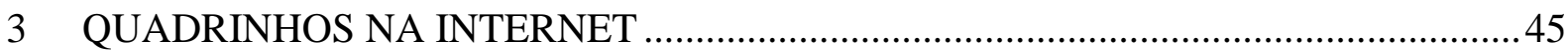

3.1 Produção e distribuiçãa de HQs online ....................................................................53

3.2 Mediações, convergência e novas possibilidades de discurso.......................................58

3.3 Redes sociais e blogosfera como formas de comunicação distribuída ..........................63

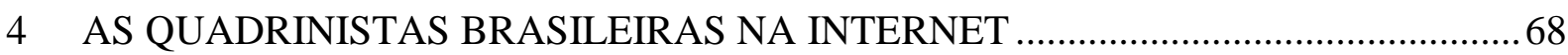

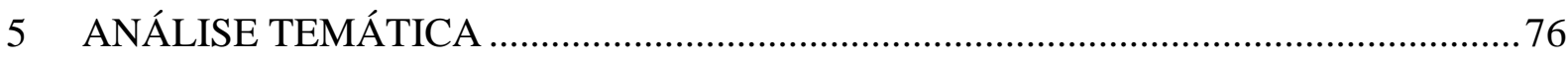

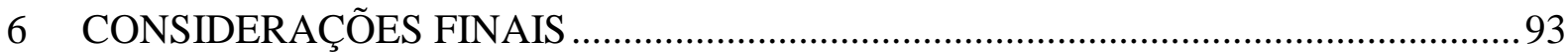

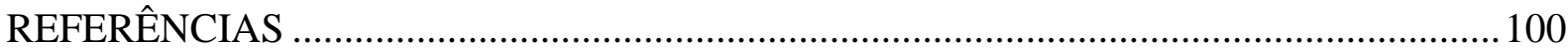

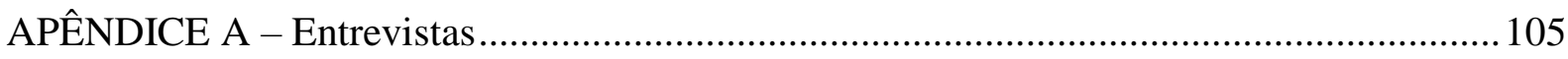

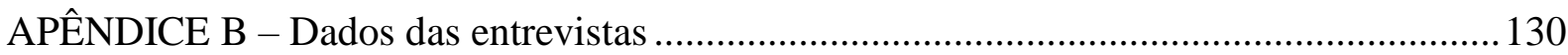

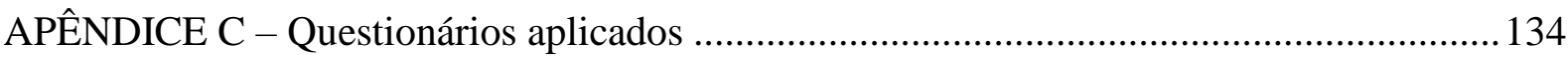

APÊNDICE D - Editoras e publicações...................................................................... 151 


\section{INTRODUÇÃ̃o}

Ao longo do século $\mathrm{XX}$ as histórias em quadrinhos se popularizaram entre as linguagens da cultura de massa, graças à evolução das técnicas de impressão, do interesse dos veículos de imprensa e da formação de um mercado editorial dedicado às HQs (SANTOS; SANTOS NETO, 2011). As mulheres sempre atuaram na indústria dos quadrinhos, como roteiristas, coloristas e editoras, embora em cargo de criação elas tivessem que adotar estratégias como ocultar o primeiro nome para serem mais aceitas entre o público (NOGUEIRA,2015). Com o movimento dos quadrinhos underground nos Estados Unidos e Europa, elas passaram a desenvolver as próprias publicações, se organizando em coletivos como o Wimmen's Comix, coordenado pela quadrinista norte-americana Trina Robbins, na década de 1970 (ROBBINS, 2009).

No Brasil, a lacuna de representatividade feminina no mercado editorial de quadrinhos e na imprensa (BARCELLOS, 2016), bem como a falta de um espaço em que leitores pudessem acessar e discutir sobre produções de mulheres, impulsionou a criação de plataformas em que tudo isso pudesse ser contemplado, já no século XXI. Existem eventos especializados em HQs (como o FIQ, Comic Com Experience e feiras de publicações independentes, como Miolos, Plana e Ugra Fest) e grupos criados nas redes sociais para discutir o assunto (como, por exemplo, Quadrinhólatras, Divulgando quadrinhos independentes e Quadrinheiros, na rede social Facebook), mas é possível que essas iniciativas não sejam capazes de refletir a quantidade e complexidade dos trabalhos que têm sido desenvolvidos por mulheres, sobretudo, os desenvolvidos fora das capitais onde os eventos costumam ser realizados e que são divulgados por meio da internet.

Em 2015, a $27^{\mathrm{a}}$ edição do Troféu HQMIX, que se intitula como o "Oscar dos quadrinhos brasileiros", contou com, aproximadamente, $82 \%$ de pré-indicações masculinas (121 obras feitas exclusivamente por homens) e 13\% de pré-indicações femininas (19 obras feitas exclusivamente por mulheres) - o restante são obras feitas a partir de parcerias entre homens e mulheres ou coletâneas nas quais não foi possível identificar todos os autores envolvidos. Em 2016, o processo de votação teve alterações e o público em geral pode votar para decidir as pré-indicações por meio de formulários preenchidos online ${ }^{1}$

\footnotetext{
${ }^{1}$ Dados sistematizados pela autora, divulgados em HQMIX. Conheça os indicados do troféu HQMIX 2105. Online. [S/d.]._Disponível em < http://hqmix.com.br/blog/noticias/conheca-os-indicados-ao-trofeu-hqmix-2015/> Acesso em: 15 julho de 2018.
} 
No Festival Internacional de La Bande Desinné d'Angoulême, o maior evento de premiação de quadrinhos da Europa, nenhuma mulher foi indicada na categoria mais importante para os autores, em 2016, algo que foi noticiado em várias partes do mundo e mobilizou mulheres quadrinistas, sobretudo, nas redes sociais. Foi criada a campanha "Women do BD", nas redes sociais, convidando artistas a criarem quadrinhos sobre a falta de mulheres indicadas ao prêmio de Angoulême e a postarem a hashtag "\#WomenDoBD" (ATHAYDE, 2016).

Isso mostra que o campo dos quadrinhos, assim como muitos outros campos profissionais e artísticos, ainda é um espaço no qual predomina o reconhecimento do trabalho masculino. A proposta de investigação deste objeto de pesquisa justifica-se pela relevância da formação de um cenário em que as mulheres passam a contestar a falta de visibilidade e representação no meio dos quadrinhos, reivindicando um espaço "próprio", utilizando os recursos da internet como ferramenta de divulgação e discussão. A lacuna de representatividade não é uma condição exclusiva do cenário das HQs, mas considera-se que a análise do corpus desta pesquisa, que corresponde a trabalhos de mulheres que publicam de forma independente na internet no Brasil, é capaz de contribuir para levantar diversos questionamentos acerca das expectativas sobre o papel da mulher contemporânea.

O objetivo geral deste trabalho foi elaborar um panorama das principais publicações online de histórias em quadrinhos feitas por mulheres no Brasil. Dentre os objetivos específicos, buscou-se: a) mapear e documentar as principais publicações de quadrinhos feitos por mulheres para publicação online, por meio de buscas nas plataformas Lady's Comics e Zine $X X X ; b)$ entrevistar as autoras selecionadas para compreender de que modo o trabalho foi idealizado e os resultados, em termos de visibilidade e legitimidade de suas produções; c) identificar os principais temas abordados nas HQs; e d) realizar análise temática, buscando identificar as diferenças entre publicações do mercado editorial impresso e as HQs independentes publicadas online por mulheres.

Criado em 2010, o site Lady's Comics traz o slogan "HQ não é só para o seu namorado". O site aborda "mulheres que estão presentes (ou que já se foram) no universo dos quadrinhos", de acordo com o texto de apresentação da página do Facebook. A página inserida nessa mesma rede social possui mais de 20 mil curtidas e, em 2014, foi realizado o $1^{\circ}$ Encontro Lady's Comics, em Belo Horizonte, financiado por crowdfunding (pela plataforma Catarse, de financiamento coletivo). Em 2017, as coordenadoras declararam nas redes que não vão mais desenvolver o trabalho, por motivos pessoais e de trabalho, mas o conteúdo seguirá disponível na íntegra para fins de consulta. 
A iniciativa do Zine $X X X$ surgiu no início de 2014, a partir da manutenção de um grupo de discussão sobre mulheres nos quadrinhos na rede social Facebook. O grupo aceita a participação exclusiva de mulheres e funciona como um espaço de socialização da produção feminina, discussões sobre gênero, organização de atividades e eventos ligados aos quadrinhos. O Zine $X X X$ é referência de um espaço acolhedor para artistas que estão começando e que se deparam com um cenário ocupado historicamente por homens e pouco permeável à atuação feminina. A idealizadora do projeto é Beatriz Lopes, que se dedicou a reunir 70 mulheres para produção de 5 zines, além do grupo de discussão, que possui mais de 3 mil membros.

Compreendendo o método de análise de conteúdo como um "conjunto de técnicas de análise das comunicações" (BARDIN, 1988, p. 33) a pesquisa analisa as publicações contidas nos sites e grupos nas redes sociais que enfoquem a produção feminina de quadrinhos. Realizou-se um levantamento das publicações de quadrinhos feitos por mulheres a partir dos registros contidos no site Lady's Comics e grupo Zine XXX. Foram consideradas histórias contínuas, com enredo que se desenvolve ao longo das atualizações em plataforma on-line, desconsiderando blogs e sites de tirinhas, cartuns, charges e histórias avulsas. A justificativa para o recorte se deu pelo volume de HQs feitas mulheres encontradas nas plataformas que serviram como ponto de partida para coleta da amostra. Foram analisados 62 registros no site do Lady's Comics e mais de 100 no grupo Zine XXX. Em ambos os casos, os registros foram feitos de forma voluntária pelas próprias artistas.

A partir desse levantamento, das entrevistas com as autoras e da análise de conteúdo, foi elaborado um quadro sinóptico sobre os temas mais recorrentes abordados nas HQs. A análise temática ajuda a compreender como as webcomics reforçam ou contrariam os temas que costumam ser valorizados pelo mercado editorial, dentro do que se considera uma produção feminina de quadrinhos.

A primeira fase da pesquisa, que consistiu no levantamento e revisão bibliográfica, teve como foco leituras ligadas à economia e circulação de HQs, buscando identificar a inserção das mulheres nesse sistema. A temática de gênero também permeia o levantamento bibliográfico, uma vez que justifica o recorte escolhido nesta pesquisa e ofereceu fundamentos para compreender a lacuna de representatividade feminina.

Também foram realizadas entrevistas com as autoras e aplicação de questionários estruturados, com o objetivo de realizar uma análise qualitativa da amostra. Para Alves e Silva (1992, p. 65) a "análise qualitativa se caracteriza por buscar uma apreensão de significados na 
fala dos sujeitos, interligada ao contexto em que eles se inserem e delimitada pela abordagem conceitual (teoria) do pesquisador”.

É preciso ressaltar que a área da Ciência da Informação "se desenvolve gerando sempre zonas interdiscursivas" e que várias áreas do conhecimento devem ser mobilizadas para que a pesquisa "tenha de fato um caráter interdiscursivo ou transdisciplinar de cunho informacional”, conforme pontua González de Goméz (2000, p. 7). A análise de conteúdo pode ser sintetizada como um esforço de articular os saberes quantitativos e qualitativos na interpretação da mensagem:

São analisadas as palavras, as frases e temas que dão significação ao conjunto, para relacioná-las com os dados pessoais do autor, com a forma literária do texto, com o contexto sociocultural do produtor da mensagem: as intenções, as pressões, a conjuntura, a ideologia que condicionaram a produção da mensagem, em um esforço para articular o rigor objetivo, quantitativo, com a riqueza compreensiva, qualitativa (CHIZZOTTI, 2010, p. 116-117).

A abordagem quantitativa foi adotada para contabilizar as publicações femininas de HQs pertencentes à amostra, as principais temáticas envolvidas nessas produções e os títulos publicados por editoras brasileiras, que serviram de base para as reflexões propostas neste projeto. Os dados quantitativos foram expressos a partir da elaboração de categorias, que indiquem a frequência, presença ou ausência de determinados temas contidos na amostra.

Nas análises quantitativa e qualitativa, a influência do contexto deve ser considerada para que a interpretação dos números seja feita de modo satisfatório, assim, cabe levar em conta "quais serão as condições de produção, ou seja, quem é que fala a quem e em que circunstâncias? Qual será o montante e o lugar da comunicação? Quais os acontecimentos anteriores ou paralelos?" (BARDIN, 1988, p. 141).

Em suma, a pesquisa de abordagens quantitativa e qualitativa pode ser definida da seguinte maneira:

A abordagem quantitativa funda-se na frequência de aparição de determinados elementos da mensagem. A abordagem não quantitativa recorre a indicadores não frequenciais susceptíveis de permitir inferências; por exemplo, a presença (ou ausência) pode constituir um índice tanto (ou mais) frutífero que a frequência de aparição (BARDIN, 1988, p. 140).

A pesquisa foi desenvolvida em nível exploratório, por meio de levantamento bibliográfico e entrevistas, com o objetivo de "proporcionar visão geral, de tipo aproximativo, acerca de determinado fato". O nível explicativo também será presente à medida que há uma "preocupação central identificar os fatores que determinam ou que contribuem para a ocorrência dos fenômenos" (GIL, 1994, p. 46). 
Nos primeiros capítulos optou-se por realizar uma reconstituição histórica da atuação feminina no mercado editorial de quadrinhos no Brasil, com o objetivo de compreender os caminhos que levaram ao modo atual de produção de mulheres, que inclui a publicação de HQs online. Percebemos que, para entender o mercado editorial brasileiro seria necessário entender a história do mercado norte-americano, por conta da importação de títulos e modelos de negócio.

Feito o levantamento bibliográfico sobre a história dos quadrinhos norte-americanos e brasileiros, optou-se por comentar brevemente as publicações femininas que adquiriram projeção além das fronteiras do próprio país de origem, sobretudo no fim do século XX e início deste século, no capítulo "Elas por elas no mundo". O objetivo dessa seção foi de compreender como algumas mulheres e suas produções se tornaram objeto de interesse de editoras e da imprensa, atingindo um público amplo, como no caso das autoras de mangás no Japão e as graphic novels autobiográficas. Também realizamos um levantamento das publicações de autoria feminina feitas pelas principais editoras independentes do Brasil, com o objetivo de compreender as escolhas editoriais, entre ficcionais e não ficcionais, mais recorrentes.

Buscando compreender os antecedentes que levaram as mulheres brasileiras à produção independente on-line, realizamos uma pesquisa sobre o auxílio das ferramentas digitais, tanto na produção quando disseminação de HQs, no capítulo "Quadrinhos na internet". Identificou-se os processos de compartilhamento e apropriação da informação que se enquadram, sobretudo, nos conceitos de convergência, proposto por Jenkins (2008), e das mediações culturais, de Davallon (2003). Nesse ponto, utilizou-se como ponto de partida para análise as iniciativas Lady's Comics e Zine $X X X$, que se desenvolvem por meio das redes sociais e reúnem leitores e quadrinistas mulheres em torno de interesses comuns. O assunto também perpassou pela discussão sobre comunicação distribuída, conceito proposto por Ugarte (2008), em que se considerada a produção de conteúdo independente como uma das bases do ciberativismo online. No caso, associou-se à produção feminina como parte das reivindicações sobre igualdade de gênero na contemporaneidade, que ultrapassam o universo dos quadrinhos e migram para ações off-line.

Após o mapeamento das autoras de webcomics, dedicou-se um capítulo a narrar a trajetória das artistas selecionadas - incluindo premiações, publicações independentes impressas ou via editoras, escolhas feitas para publicação on-line -, com base em entrevistas feitas com as oito autoras, no capítulo "As quadrinistas brasileiras na internet". Ao final do capítulo, reunimos algumas respostas representativas contendo a opinião das artistas sobre 
representatividade, visibilidade e legitimidade dos quadrinhos publicados na internet, com o objetivo de mapear estratégias que possam ser úteis a outras mulheres quadrinistas, bem como para artistas e produtores de conteúdo independente on-line.

Por fim, a análise temática foi feita com o objetivo de identificar os principais temas abordados pelas webcomics e em que medida as escolhas refletem os filtros do mercado editorial de HQs no Brasil que prioriza determinados tipos de temas e opções narrativas. 


\section{ECONOMIA E CIRCULAÇÃO DE QUADRINHOS IMPRESSOS}

Destacar aspectos da trajetória do mercado editorial norte-americano é relevante pela influência na consolidação do mercado brasileiro de quadrinhos. Gonçalo Junior (2004) faz uma reconstituição histórica da formação do mercado editorial de quadrinhos no Brasil e a atuação de grandes figuras da imprensa como os jornalistas Adolfo Aizen (jornal A Nação, EBAL), Roberto Marinho ( $O$ Globo) e Assis Chateaubriand (Diários Associados), que foram os principais responsáveis por alavancar esse mercado e formar gerações de leitores de HQs.

A história da chegada dos quadrinhos norte-americanos ao Brasil começa em 1933, quando Aizen, durante uma viagem aos Estados Unidos, conheceu os suplementos de quadrinhos que acompanhavam as edições dos jornais e que haviam se tornado populares entre um público de várias idades. $\mathrm{O}$ editor descobriu que muitos leitores compravam jornais apenas para adquirirem os suplementos, o que alavancava as vendas. As histórias em quadrinhos eram chamadas de comics pelos americanos "porque os primeiros artistas exploraram o gênero para fazer graça com o universo miserável dos cortiços das grandes cidades americanas no final do século XIX" (GONÇALO JUNIOR, 2004, p. 25).

Aizen se espantou ao ver que os leitores esperavam avidamente pela continuação das aventuras de seus personagens favoritos, como Tarzan e Buck Rogers, algo semelhante à leitura dos folhetins. Ao voltar ao Brasil, ele tentou emplacar a ideia de lançar suplementos como os que vira nos Estados Unidos, mas não encontrou receptividade no jornal $O$ Globo, conseguindo negociar as publicações no jornal A Nação. A proposta era publicar suplementos junto ao jornal diário, o que demandava muito trabalho ao editor, que realizava a maior parte das tarefas. Ele optou por importar quadrinhos norte-americanos, por meio de representantes dos syndicates, que eram agências que distribuíam ilustrações, quadrinhos, reportagens e artigos.

Os leitores depararam, pela primeira vez, com os quadrinhos que eram grandes sucessos nos Estados Unidos naquele momento: Buck Rogers, Agente Secreto X-9, Flash Gordon [...] e Jim das Selvas. Nos anos seguintes, Aizen traria Mandrake, Brucutu, Príncipe Valente, Tarzan, Brick Bradford, Pinduca, Rei da Polícia Montada e até mesmo histórias inéditas de Walt Disney, que começava a chamar atenção pelo perfeccionismo em cinema de animação (GONÇALO JUNIOR, 2004, p. 31).

O início da popularização dos quadrinhos no Brasil é marcado pelo sucesso entre o público infantil, publicados no Suplemento Infantil (criado por Aizen) e, anteriormente, os quadrinhos feitos no Brasil por Angelo Agostini e publicados No jornal A Vida Fluminense, 
na primeira década do século XX. O termo "gibi", frequentemente usado para se referir aos quadrinhos voltados para o público infantil, também surgiu em meados da década de 1940, quando Marinho criou uma revista de quadrinhos, a Gibi, para concorrer com publicação semelhante lançada por Aizen, a revista Mirim. Gonçalo Junior (2004, p. 69) explica que “Mirim, em tupi, é o mesmo que 'pequeno'; gibi é usado como sinônimo de 'moleque', 'garoto', 'negrinho'”.

Ao se desligar do jornal A Nação, Aizen fundou sua própria editora para publicar o Suplemento Juvenil. Em resposta, Roberto Marinho, principal concorrente de Aizen, lançou $O$ Globo Juvenil, que publicava somente quadrinhos norte-americanos e ingleses. A disputa entre Aizen e Marinho marca a entrada maciça de quadrinhos estrangeiros, sobretudo, vindos dos Estados Unidos, no Brasil, graças à mediação de representantes dos syndicates.

Junto com os títulos de sucesso, foi importado também um novo formato de publicação de HQs, o comic book, que era um jornal tabloide dobrado e grampeado. A novidade lançada pelos comic books era a publicação de histórias completas, ao invés das histórias seriadas publicadas nos suplementos de jornais. De acordo com Gonçalo Junior (2004, p. 66) “como acontecia nos Estados Unidos, esse tipo de revista iria, a médio prazo, dominar o mercado brasileiro de quadrinhos e decretar a morte do tabloide durante a década de 40".

\subsection{O mercado editorial norte-americano e a atuação feminina}

A atuação das mulheres como profissionais dentro das editoras de quadrinhos é marcada por movimentos de avanço e retrocesso, como reflete Chenault (2007), que reconstitui essa atuação, desde a década de 1930 até 1990, nos Estados Unidos. O autor observa que havia mais mulheres trabalhando em cargos que não estavam diretamente ligados à criação, como, por exemplo, colorização e letreiramento. Em grandes editoras como a Marvel, na década de 1940, era comum que as profissionais não recebessem crédito pelos seus trabalhos, usassem pseudônimos com nomes masculinos ou assinassem apenas o sobrenome para ocultar o sexo e, assim, atraírem mais atenção para suas produções.

A norte-americana Rose O’Neil, criadora da série Kewpies, de muito sucesso na primeira década do século XX, é considerada a primeira cartunista mulher a publicar seu trabalho nos Estado Unidos. June Tarpé Mills criou, em 1941, a personagem Miss Fury, que teria sido a primeira super-heroína dos quadrinhos. A quadrinista foi quem roteirizou e ilustrou a história e assinava apenas o sobrenome, como uma estratégia para que os editores e leitores se interessassem pelo seu trabalho (NOGUEIRA, 2015). 
Figura 1 - Capa da HQ Miss Fury de June Tarpé Mills (Marvel)

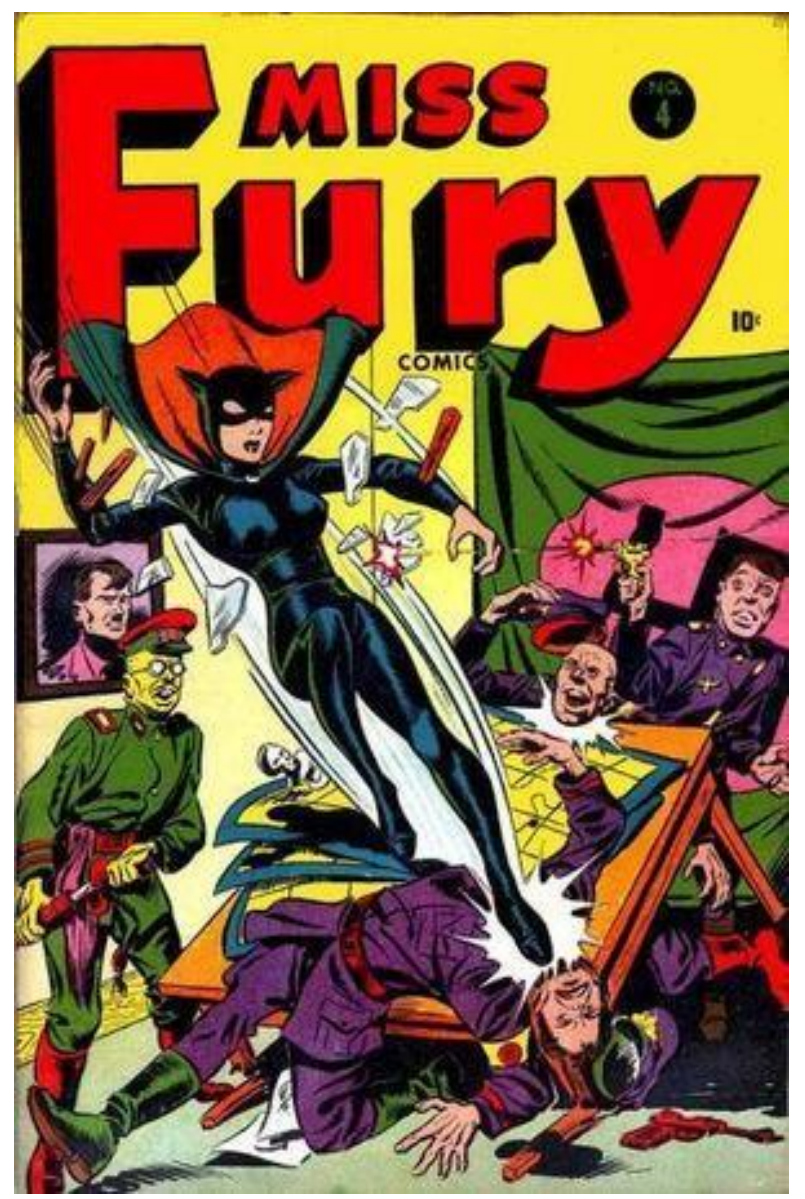

Fonte: http://marvel.wikia.com/wiki/Miss_Fury_Vol_1_4 (2018)

A Segunda Guerra Mundial marca a entrada de muitas mulheres no mercado de quadrinhos pela necessidade de substituição da mão de obra masculina que havia sido recrutada para a guerra. De acordo com Nogueira (2015, p. 86) as personagens não eram "super-heroínas, mas desempenharam um papel bem parecido, inspiradas no dever cívico", ou seja, as personagens, assim como as mulheres da época, estavam de alguma forma envolvidas com a guerra. Nessa época, surgem personagens como Miss América, Mulher Maravilha e a série Girl Commandos. Durante a Segunda Guerra Mundial, outra autora que obteve êxito no mercado de quadrinhos norte-americano foi Delia Messick, que criou a personagem Brenda Star.

A entrada maciça de mulheres no mercado de trabalho, seja para suprir o vazio deixado pelos homens que estão no front de batalha, seja para preencher uma demanda surgida com a eclosão da guerra, irá causar um grande impacto social, durante e depois do conflito. Elas não são super-heroínas, mas desempenharam um papel bem parecido, inspiradas 
no dever cívico e muitas, possivelmente, naquelas mulheres de papel, corajosas e audaciosas, como a Mulher Maravilha e Miss Fury e muitas outras personagens populares daquela época. Reais ou imaginárias, elas estão envolvidas na guerra. A participação das mulheres nas forças armadas merece destaque (NOGUEIRA, 2015, p. 86).

A chamada "Era de Ouro", tanto para o mercado de quadrinhos quanto para as mulheres quadrinistas, acaba com o fim da guerra e a volta dos homens a seus postos de trabalho. Em 1950, o backlash cultural (onda de conservadorismo em que as mulheres eram coagidas a retomarem atividades ligadas à família, fora do mercado de trabalho) e a campanha contra os quadrinhos lançada por Fredric Wertham, psiquiatra do New York Department of Hospitals, fez com que muitas mulheres perdessem seus cargos nas editoras. Boff (2014, p. 33) explica que o período é marcado pela "consolidação da propaganda da vida doméstica para as mulheres", já que o trabalho feminino fora do lar já não era desejado.

Wertham, em seu livro de grande sucesso comercial, Seduction of the Inocent (Sedução do Inocente), alegava que a leitura de quadrinhos produzia um efeito perigoso na mente de crianças e adolescentes, por conta dos conteúdos envolvendo crimes, sexo e violência (NOGUEIRA, 2015). A onda de crimes cometidos por jovens da época motivou a interpretação de Wertham de que os comics estavam associados a comportamentos violentos, como observa Gonçalo Junior:

Wertham publicou um tratado implacável contra os comics com base em
conclusões que teria tirado dos tratamentos feitos em sua clínica em crianças
e adolescentes com distúrbios de comportamento. A obra denunciava, de
modo contundente, que terríveis crimes praticados por crianças nos últimos
anos foram estimulados pela leitura dos comics. (GONÇALO JUNIOR,
2004 , p. 235

No mesmo ano em que o livro foi lançado, as editoras de quadrinhos norte-americanas se reuniram para fundar a Comics Magazine Association of America - CMAA (Associação Americana de Revistas em Quadrinhos), que teria como função estabelecer padrões de qualidade para os quadrinhos, garantindo que as histórias não teriam conteúdos que pudessem estimular o mau comportamentos dos leitores. Nas reuniões da CMAA foi elaborado o Comics Code Authority, "uma tábua de auto-regulamentação com regras que censuravam o conteúdo das histórias" (GONÇALO JUNIOR, 2004, p. 242).

A aplicação do código inibiu a produção criativa dos comics e provocou uma crise no mercado até o final da década de 1950. Se no mainstream os quadrinhos eram censurados, a alternativa para alguns artistas era publicar fora dos circuitos comerciais tradicionais, ou seja, no mercado underground. Isso resultou em um movimento que revolucionou a noção sobre os 
assuntos que os quadrinhos poderiam abordar e, sobretudo, como isso poderia ser feito, a partir da década de 1960, os chamados comix (CHUTE, 2010).

Esse movimento abriu caminho para experimentações e histórias que fugiam das fórmulas narrativas das HQs de super-heróis e de aventura, que terminam com uma lição de moral. É reforçada a figura do anti-herói, como o personagem Harvey Pekar, na série desenhada por Robert Crumb e roteirizada por Pekar, intitulada American Splendor e publicada a partir de 1976. A série desmascara o sonho americano, revelando um protagonista cuja existência é fracassada e medíocre. O filme American Splendor, lançado em 2003, com direção de Shari Berman e Robert Pulcini, foi criado a partir da série em quadrinhos e teve o título traduzido para o Brasil como Anti-herói americano.

Nessa época, a cultura dos fanzines se fortaleceu e muitos autores independentes passaram a publicar, com inspiração no humor satírico da revista Mad, fundada pelo quadrinista Harvey Kurtzman, ainda na década de 1950. Os fanzines eram produzidos por jovens, com materiais de baixo custo e distribuídos informalmente. Teria sido nessa fase que o termo "graphic novel" foi usado publicamente pela primeira vez:

Em 1964, em um boletim de notícias que circulava entre os membros da Amateur Press Association, foi utilizado publicamente, pela primeira vez, o termo graphic novel, por Richard Kyle. O termo foi posteriormente apropriado por Bill Spencer, em seu fanzine Graphic Story World (CHUTE, 2010, p. 15, tradução nossa). O que CHUTE (2010) chama de imprensa underground também foi viabilizada pela tecnologia de impressão offset, que tornou possível publicar jornais em formato tabloide com baixo custo, como Los Angeles Free Press, Berkeley Barb, East Viallage Other, San Francisco Oracle, Detroit's Fifth State e Chicago Seed. Nessas publicações, as HQs refletiam a contracultura dos anos 60, que nada tinham a ver com os quadrinhos de editoras como Marvel e DC Comics. As histórias lidavam com abordagens "adultas, identitárias, experimentais e confessionais" (CHUTE, 2010, p. 14).

Alternativas no modo de distribuição de quadrinhos também foram importantes para o desenvolvimento da imprensa underground. Lee Marrs (que trabalhou como assistente do quadrinista Tex Blaisdell, na tira de jornal Little Orphan Annie) formou, em 1971, o Alternative Features Syndicate (AFS), para distribuir notícias, imagens e quadrinhos para os jornais underground. Robbins (2009) considera Lee Marrs como uma das founding mothers (mães fundadoras) dos quadrinhos underground. 
Figura 2 - Capa da HQ Pudge, de Lee Marrs

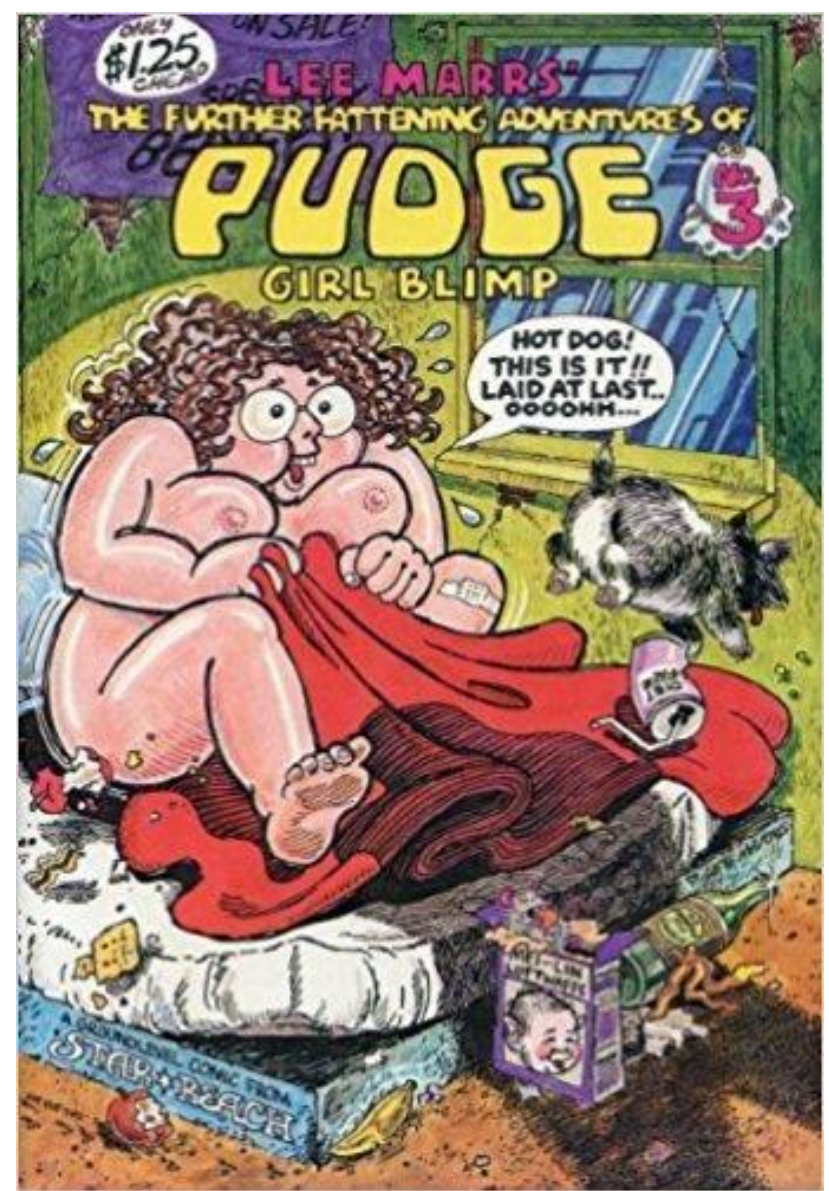

Fonte: https://br.pinterest.com/pin/186758715772433687/ (2018)

O autor mais emblemático, quando se discute o lado confessional e experimental dos quadrinhos underground, foi Robert Crumb, criador da revista Zap Comix e referência para muitos artistas de gerações posteriores. Temas como raça e sexualidade eram recorrentes em seus quadrinhos, revelando aspectos grotescos e misóginos de sua personalidade. As produções de Crumb foram como um gatilho para que o movimento feminista de segunda onda - com foco na "luta pela valorização do trabalho da mulher, o direito ao prazer, contra a violência sexual" e contra governos ditatoriais (RIBEIRO, 2014) - começasse a discutir sobre as representações da mulher nos quadrinhos. Robbins (2009) conta que, quando mulheres se manifestavam contra os enredos destinados às personagens femininas, envolvendo tortura, assassinato e estupro, eram taxadas de pessoas sem senso de humor pelos homens.

Ao mesmo tempo em que elas sentiam repulsa pelo modo degradante como as mulheres eram retratadas, quadrinistas contemporâneas consideram que esses autores foram referências importantes para seus próprios trabalhos.

Por mais que o conteúdo fosse repulsivo, o viam como algo impressionante e eletrizante. Enquanto Crumb influenciou Justin Green e Spiegelman, entre 
outras figuras marcantes dos quadrinhos, ele também inspirou a maioria das autoras analisadas neste livro: Aline Kominsky-Crumb (que se casou com ele em 1978), Alison Bechdel (que viu o trabalho de Crumb quando era criança e foi "hipnotizada por sua arte", afirmando que ele é uma "grande influência", e um "gênio gráfico"), Phoebe Gloeckner e Lynda Barry (CHUTE, 2010. p. 16, tradução nossa).

Crumb também foi referência para outros dois artistas que são conhecidos por publicarem suas obras no formato de graphic novel e com conteúdo autobiográfico, marcando o início de um mercado que se prolifera até hoje e que levou as HQs para os estandes das livrarias não especializadas. Os artistas são: Justin Green (que publicou A Contract With God, Binky Brown Meets the Holy Virgin Mary e Funny Animals, na década de 1970) e Art Spiegelman (autor de Maus, publicado em dois volumes, o primeiro em 1986 e o segundo em 1991). Green fazia relatos autobiográficos envolvendo temas ligados à sexualidade masculina, incluindo suas próprias experiências negativas. Green abriu caminho para a entrada dos quadrinhos autobiográficos no mercado underground e sua forma de abordar a sexualidade fora dos padrões ajuda a compreender como "as histórias em quadrinhos se prestaram às preocupações feministas sobre representação" (CHUTE, 2010, p. 19, tradução nossa).

Figura 3 - Auto-retrato de Justin Green na HQ Binky Brown Meets the Holy Virgin Mary

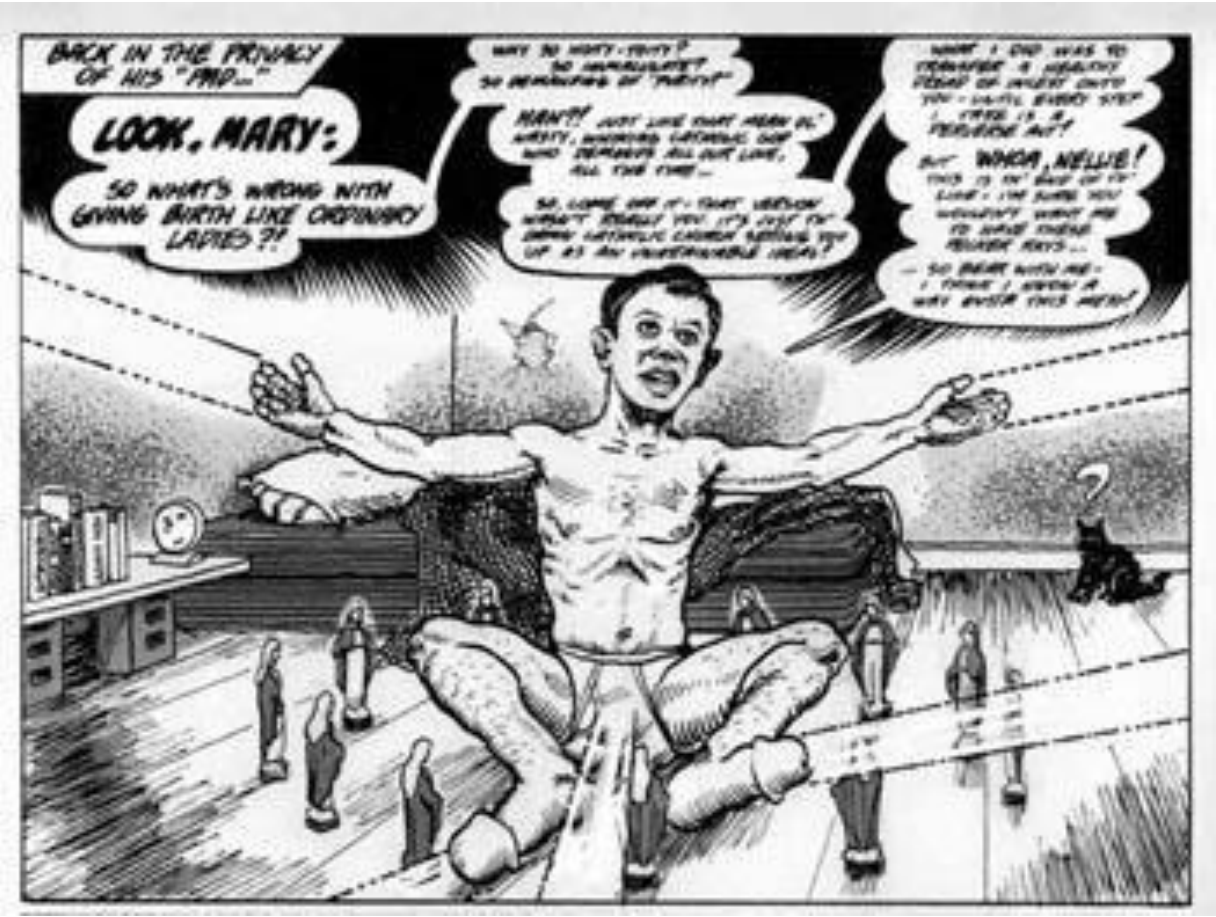

Fonte: http://www.tcj.com/the-abcs-of-auto-bio-comix-2/binky-4/ (2018)

Até a década de 1970, nos Estados Unidos, predominou a venda de publicações de quadrinhos em bancas de jornais. Com a crise desse sistema de vendas, a saída foi encontrada com o surgimento de lojas especializadas, os comic shops, que se dirigiam a um segmento de 
público fidelizado. Isso permitiu que as editoras e donos de lojas apostassem em publicações para adultos, as chamadas graphic novels, que, em geral, possuem narrativas mais extensas e melhor acabamento, semelhante ao de livro (FRADE, 2015).

É possível que essa abertura para formatos e narrativas diferentes ao das histórias de super-heróis tenha atraído o público feminino de quadrinhos de maneira mais ampla, já que os quadrinhos que dominavam o cenário mainstream eram voltados, em grande parte, ao público masculino, a partir da construção sexista de suas personagens.

O número de mulheres no circuito mainstream caiu drasticamente no pós-guerra e foi no meio underground e na produção independente que elas encontraram novos espaços de atuação, durantes as décadas de 1960 e 1970 com as publicações de fanzines e coletâneas como It Ain't Me, Babe e Wimmen's Comix (ROBBINS, 1993). Nas décadas seguintes, as mulheres continuaram trabalhando às margens do mercado mainstream.

A quadrinista Trina Robbins começou a se manifestar em seus trabalhos no sentido de apontar que, apesar do aumento de mulheres produzindo HQs no underground, a produção de quadrinhos continuava sendo dominada pelo trabalho masculino. Trina foi quem idealizou iniciativas para que as mulheres tivessem espaço exclusivos, criando as coletâneas de mulheres mencionadas anteriormente e organizando coletivos para articular objetivos específicos para as quadrinistas:

O crescimento do movimento dos comix foi ligado ao feminismo da segunda onda, o que permitiu a criação de um corpo de trabalho explicitamente político: as feministas queixavam-se da misoginia da Nova Esquerda, o que levou as cartunistas a estabelecerem espaços exclusivos para o trabalho das mulheres (CHUTE, 2010, p. 20, tradução nossa).

Em 1972, duas mulheres decidem criar uma revista sobre a sexualidade feminina, a Tits'n'Clits, reivindicando que, apesar de os quadrinhos undergrounds retratarem a sexualidade de maneira honesta e fora dos padrões, a visão sobre a sexualidade feminina ainda era masculina, pois os quadrinhos de maior sucesso eram feitos por homens. Joyce Farmer e Lyn Chevely, com o pseudônimo de Chin Lyvely, começaram a editora Nanny Goat Productions, dedicada em abordar a sexualidade feminina (CHUTE, 2010). 
Figura 4 - Capa da coletânea Tits'n'Clits

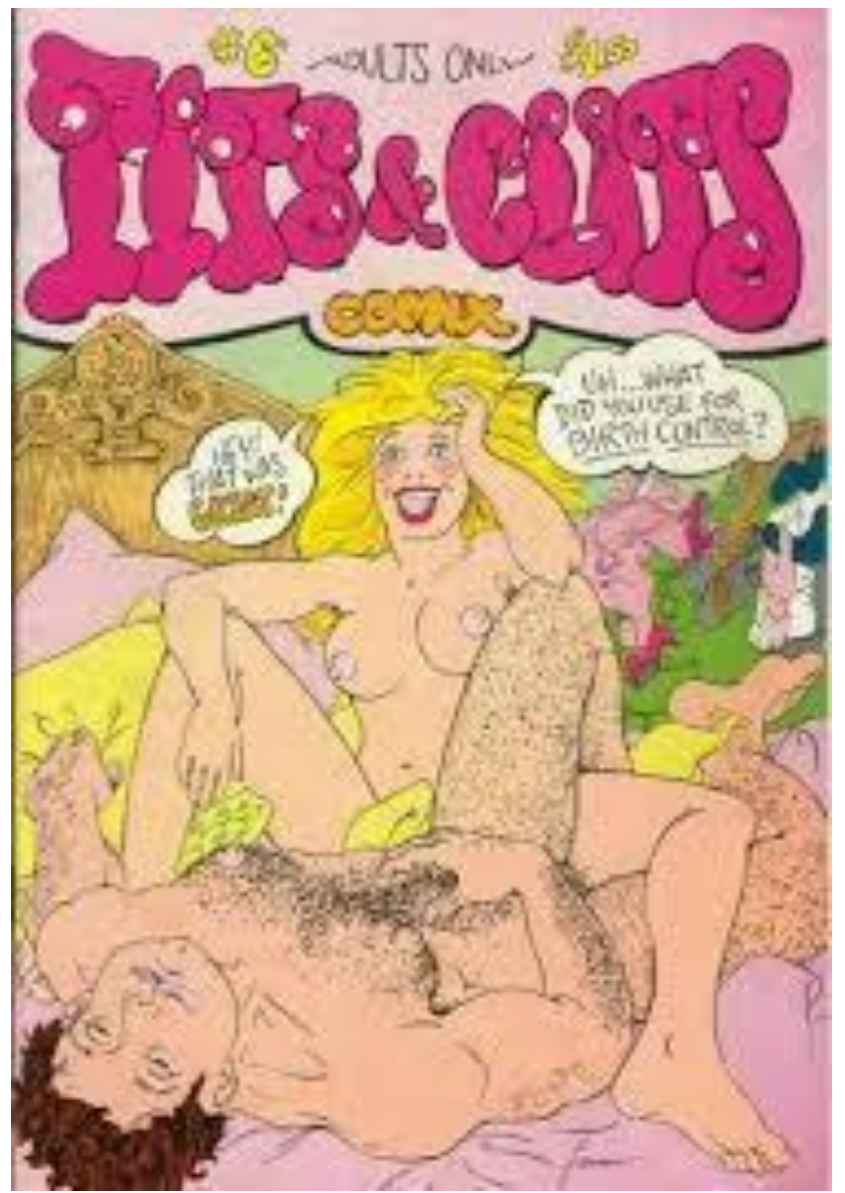

Fonte: https://comicvine.gamespot.com/tits-clits-6/4000-260535/ (2018)

Alice Kominsky-Crumb foi uma das pioneiras em retratar a própria sexualidade, mas seus trabalhos não foram publicados na Tits' n'Clits. Ela participou das edições da Wimmen's Comix, feita por um grupo de dez mulheres, inicialmente, e com edição de Trina Robbins. Assim como Justin Green, Kominsky-Crumb fazia retratos sem glamour sobre a própria sexualidade (CHUTE, 2010).

Robbins (2009) relata que os métodos de produção da revista eram diferentes dos métodos utilizados pelos coletivos masculinos. Elas optaram por não ter uma liderança e, sim, trabalhos de edição rotativos, para que todas se envolvessem com a publicação, com a mesma energia. Por conta disso, a escolha do nome da publicação foi um processo que envolveu três reuniões e sugestões como "Queen Kong", que foram descartadas porque não dialogavam com os objetivos da revista. O nome vencedor, por fim, foi Wimmen's Comix, cuja primeira edição abordava temas como "aborto, lesbianismo, menstruação e abuso sexual na infância". Quadrinistas famosas como Melinda Gebbie (Lost Girls) e Roberta Gregory (Naughty Bits) publicaram seus primeiros quadrinhos na Wimmen's Comix, no início da década de 1970. 
Outros nomes importantes dos quadrinhos também participaram da publicação, como: Lynda Barry e Phoebe Gloeckner (ROBBINS, 2009).

Figura 5 - Capa da coletânea Wimmen's Comix

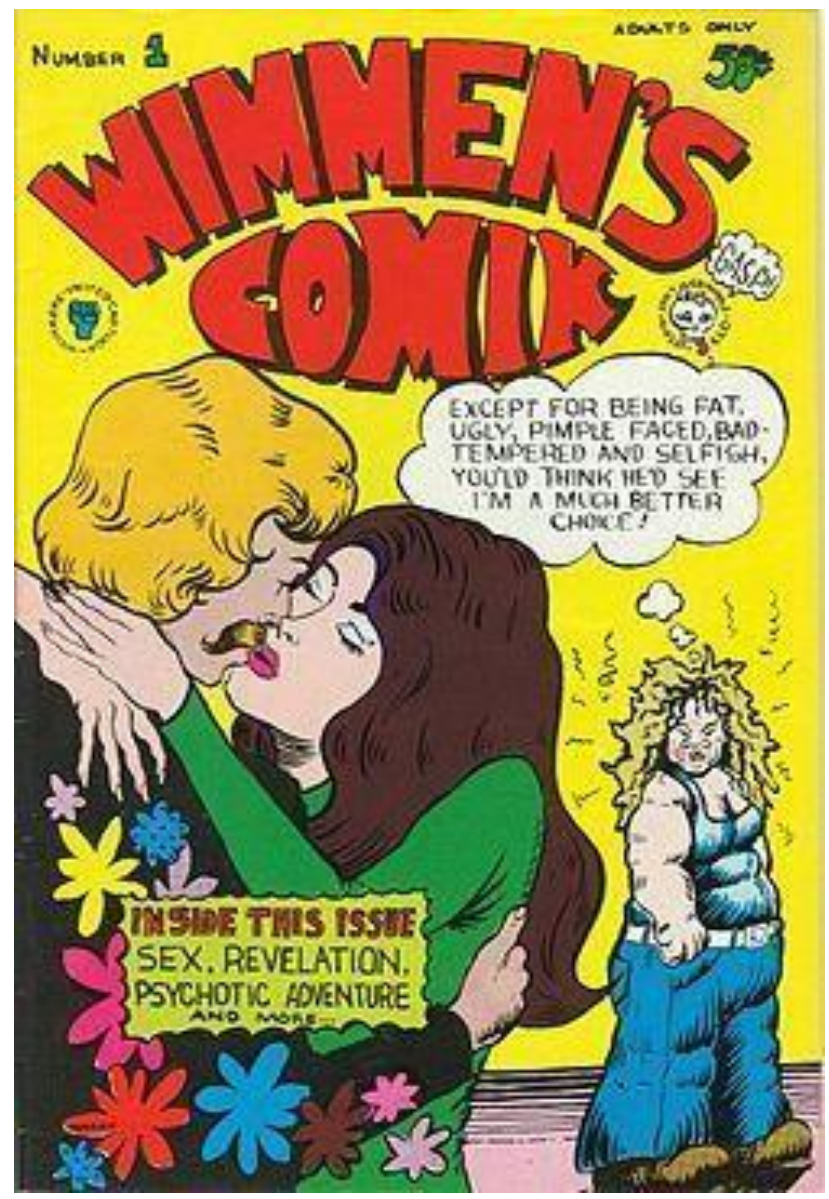

Fonte: http://www.tcj.com/an-oral-history-of-wimmens-comix/ (2018)

A coletânea tinha boas vendas nas chamadas head shops, que vendiam produtos ligados à cultura canábica, pôsteres de bandas e quadrinhos alternativos, que foram populares junto ao movimento hippie, na década de 1960. Com o declínio das head shops, a única alternativa era a vender nas tradicionais comic book stores, gerenciadas por fãs de superheróis e que não tinham interesse em adquirir "chick books" (algo como "livros de mulherzinha", em tradução nossa), alegando que mulheres não leem quadrinhos.

A coletânea teve fim em 1992 e, apesar dos obstáculos enfrentados pelas mulheres no cenário dos quadrinhos, a partir da década de 1990, Robbins firma que nunca houve uma época em que as mulheres produziram tanto. As artistas produzem de modo independente, imprimindo seus próprios fanzines ou publicando seus quadrinhos online, ou em parceria com pequenas editoras (ROBBINS, 2009). 
A coletânea Wimmen's Comix abriu espaço para que muitas artistas desconhecidas pudessem mostrar os trabalhos a um público mais amplo e serviu para mostrar que o trabalho feminino nos quadrinhos podia ser informativo e relevante (CHUTE, 2010). Outro aspecto importante desenvolvido graças à coletânea foi a produção de quadrinhos autobiográficos feitos por mulheres, o que estabeleceu um campo de trabalho mais promissor, em comparação ao trabalho nas grandes editoras de quadrinhos de super-heróis, na segunda metade do século XX.

Além de publicações exclusivas de trabalhos de mulheres, também foi na época dos comix que surgiram as primeiras revistas sobre o mundo gay e lésbico. A autora independente, Mary Wing, reagindo à lacuna de personagens homossexuais nos quadrinhos (inclusive, na Wimmen's Comix, apesar de Trina Robbins alegar o contrário), criou a revista Come Out Comix, a primeira publicação de quadrinhos sobre lésbicas. Mais tarde, em 1983, Alison Bechdel cria a série Dykes to Watch Out For, também sobre personagens gays e lésbicas, consagrando a categoria dos Gay Comix (CHUTE, 2010).

Figura 6 - Página da revista Come Out Comix, com desenho de Mary Wings

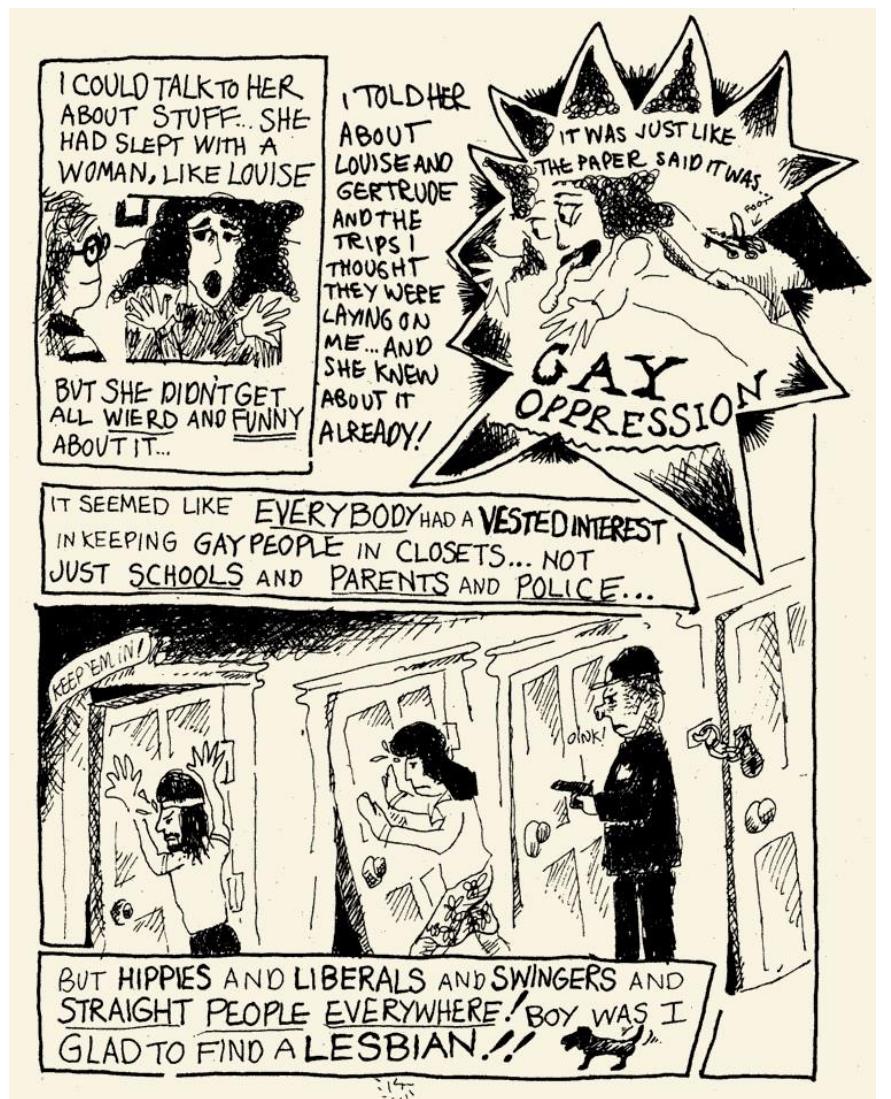

Fonte: http://www.comixjoint.com/comeoutcomix-sample1.html (2018) 
Se hoje as obras de Marjani Satrapi (2007) (Persépolis), Alison Bechdel (2007) (Fun Home e Are you my mother?), Paola Power (Vírus Tropical) e Una (Desconstruindo Una) são conhecidas em vários países, muito se deve ao trabalho desenvolvido nas coletâneas de quadrinhos feitos por mulheres e coletâneas de quadrinhos gays dos comix underground. Esse movimento começou a ser diluído no início da década de 1980, embora algumas editoras independentes tenham sobrevivido. Refletindo a utopia dos anos 60 e 70, o underground “mudou a noção do que consideramos 'literatura' e mostrou o risco da auto representação, que vemos hoje nas narrativas gráficas feitas por mulheres", colocando o "o corpo na página" (CHUTE, 2010, p. 26, tradução nossa) e mostrando diferentes perspectivas sobre gênero e sexualidade.

\subsection{Formação do mercado editorial brasileiro e atuação feminina}

A atuação das mulheres como criadoras de histórias em quadrinhos, no início do século XX, não estava vinculada diretamente a um mercado voltado para esse tipo de linguagem, mas sim, à imprensa burguesa ou ligada a movimentos políticos e artísticos de vanguarda. A jornalista e poeta Helena Ferraz de Abreu publicava na A Gazetinha, do jornal Gazeta, na década de 1930, e há suspeitas de que ela usava o pseudônimo Francisco Armond para assinar a série de tiras A garra cinzenta, fato que nunca se confirmou (SILVA, 2013). Há poucos registros sobre personalidades femininas marcantes da época, mas, entre as pioneiras das artes gráficas, podemos destacar os nomes Nair de Teffè, Patrícia Galvão, a Pagu, e Hilde Weber.

O protagonismo feminino nas artes e na produção científica é um assunto relativamente recente nos estudos acadêmicos, fruto da influência do movimento feminista, a partir da década de 1960. No Brasil, o Núcleo de Estudos Pagu, fundado na Universidade Estadual de Campinas (UNICAMP) é uma referência nos estudos sobre feminismo e evoca o apelido de Patrícia Galvão, personalidade da cena cultural e política do início do século XX, que, além de ser jornalista, escritora, crítica de arte e integrante do movimento modernista, também desenvolveu trabalhos utilizando a linguagem dos quadrinhos (BOFF, 2014).

Pagu produziu ilustrações e tirinhas para o jornal $O$ Homem do Povo, criado por ela e pelo marido Oswald de Andrade. Sua série de tirinhas tinha como título Malakabeça, Fanika e Kabelluda e contava a história de Kabelluda, a sobrinha de Malakabeça e Fanika, casal que não teve filho (FONSECA, 2012). 
Figura 7 - Tira de Pagu

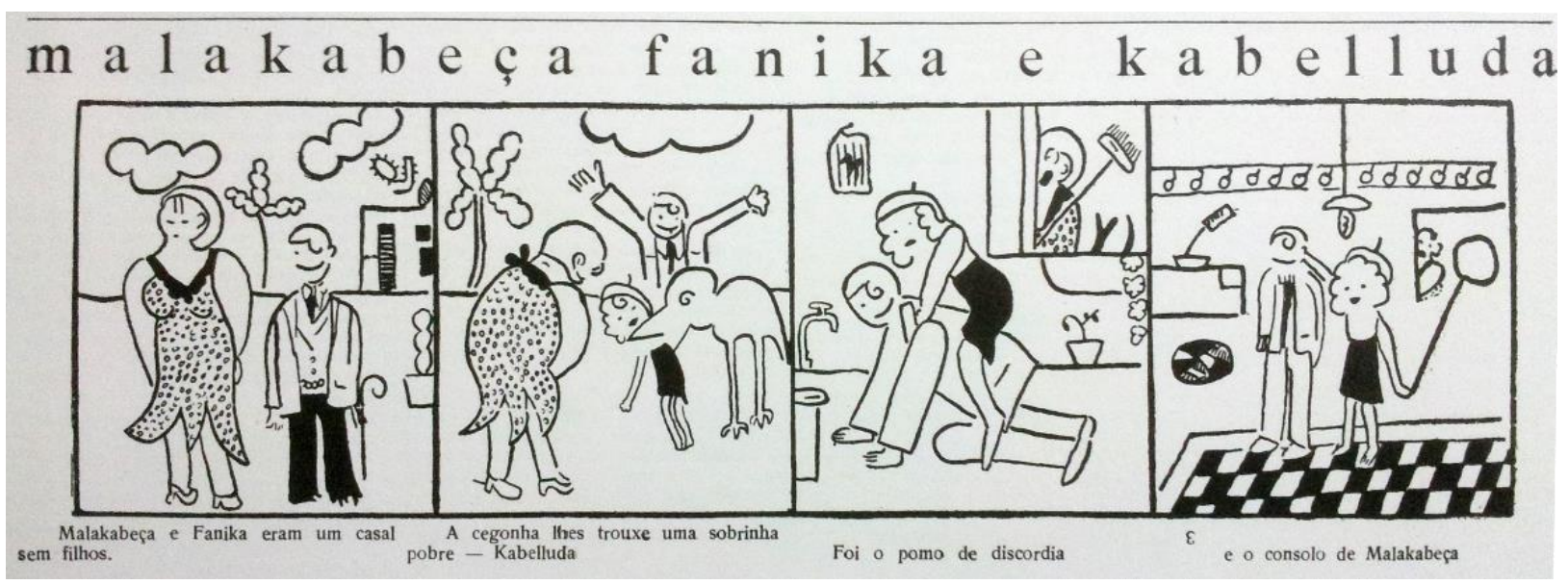

Fonte: http://ladyscomics.com.br/as-tiras-de-pagu (2018)

Nair de Teffè, que assinava seus trabalhos com o pseudônimo Rian, se aventurou mais pela arte da caricatura, produzindo retratos de personalidades da época para as revistas FonFon e $O$ Malho. Em suas caricaturas, é possível observar "o deboche crítico a respeito das figuras femininas da aristocracia (a própria artista era fruto dessa classe) com a construção exagerada de pescoços longos e peitos estufados” (BOFF, 2014, p. 221). 
Figura 8 - Caricatura de Rian

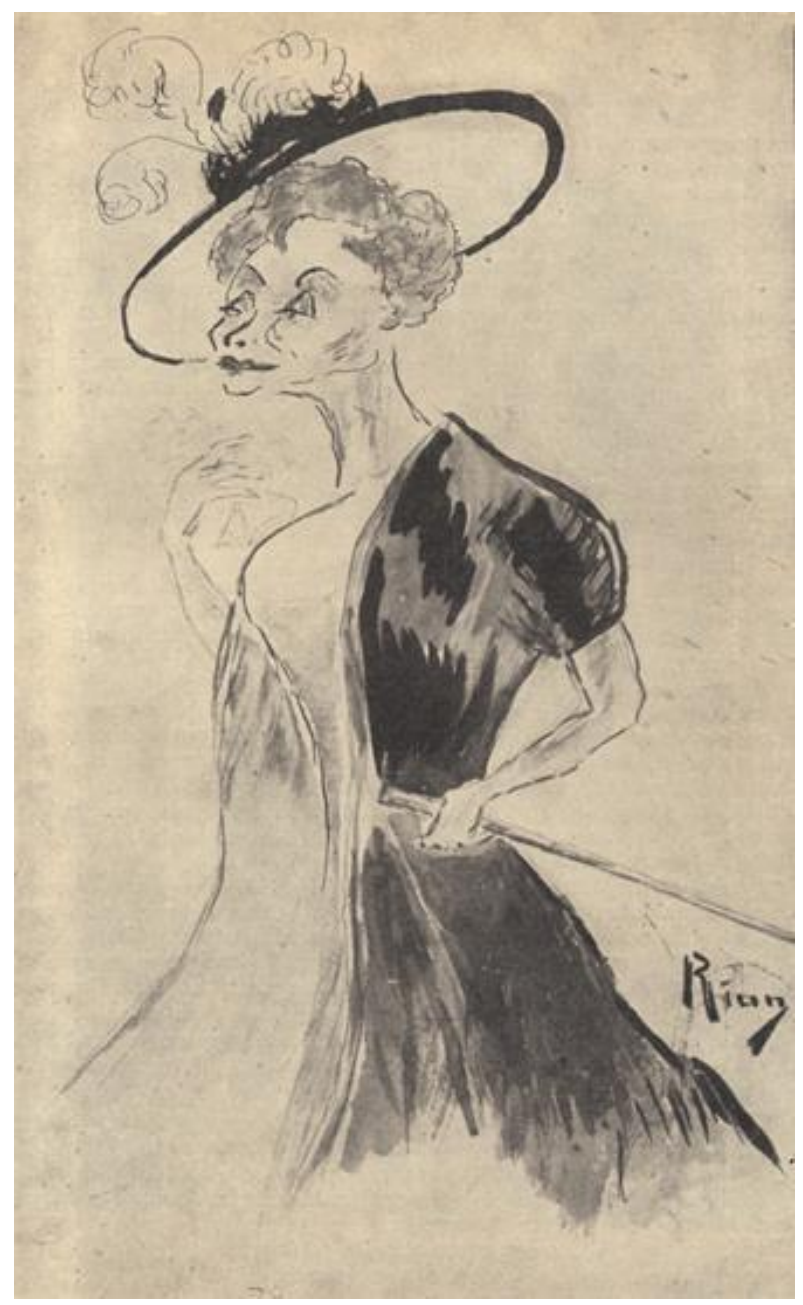

Fonte: http://sib.org.br/coluna-sib/rian-uma-mancha-pioneira/ (2018)

Nas décadas de 1930 e 1940, Hilde Weber (alemã que veio morar no Brasil) trabalhou na produção de charges políticas e caricaturas, destacando-se por suas charges sobre Getúlio Vargas. Atuou em publicações como A noite, O cruzeiro, O Estado de São Paulo e Tribuna da Imprensa (BOFF, 2014, p. 224). 
Figura 9 - Charge política de Hilde Weber

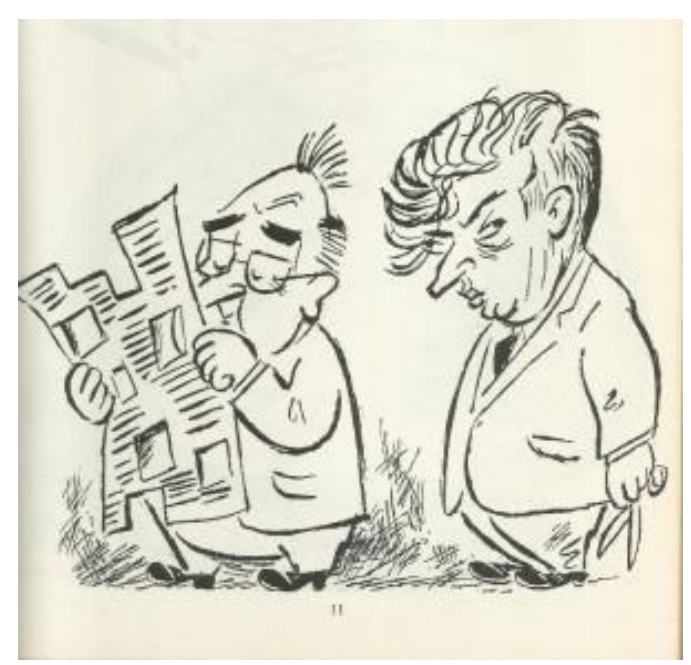

Fonte: http://historiahoje.com/hilde-weber-a-presenca-feminina-na-charge-politica-no-brasil/ (2018)

A pernambucana Conceição Cahú também atuou na imprensa na Revista Balão, em São Paulo, nos anos 70, e na Gazeta Mercantil, onde publicou suas charges e ilustrações por quase duas décadas. Seu trabalho envolvia temas ligados à situação política e econômica do país, além de reivindicações de direitos das mulheres.

Quando os quadrinhos foram trazidos ao Brasil, na década de 1930, só havia um representante dos syndicates norte-americanos. Décadas depois, novos agentes passaram a atuar no mercado editorial, o que permitiu o aumento de títulos norte-americanos publicados no país. Em 1945, Adolfo Aizen funda a Editora Brasil-América Limitada (EBAL) destinada a publicar revistas infantis, com a introdução de super-heróis brasileiros nos quadrinhos. Não demorou para que a guerra contra os quadrinhos nos Estados Unidos refletisse no mercado brasileiro.

O lançamento do livro Seduction of the Inocent, do psiquiatra Fredric Wertham, repercutiu entre a imprensa no Brasil, o que pressionou os editores das revistas de quadrinhos a criarem mecanismos de autocensura. Durante a Segunda Guerra Mundial, grupos religiosos e antifascistas lançaram campanhas contra os quadrinhos, sobretudo os de origem norteamericana, pois eram associados ao imperialismo, à perversão e ao empobrecimento da leitura concentre os jovens. Durante o Estado Novo, os quadrinhos eram alvo de investigações do Departamento de Imprensa e Propaganda (DIP), órgão responsável por censurar a imprensa e fazer propaganda do governo de Getúlio Vargas. Além disso, o Instituto Nacional de Estudos Pedagógicos (INEP) lançou os resultados de uma pesquisa sobre as consequências da leitura dos quadrinhos, publicados na Revista Brasileira de Estudos Pedagógicos. Gonçalo Junior (2004, p. 114) sintetiza que "além da tese de dominação cultural e do estímulo à violência 
promovido pelos quadrinhos, o INEP trouxe uma preocupação a mais aos pais: segundo aquela pesquisa, quem lia quadrinhos ficava com preguiça mental e avesso a livros".

Aizen aplicou recomendações do Comics Code norte-americano nos títulos da EBAL, além de lançar publicações com temáticas educativas e religiosas para agradar certos setores da sociedade. Havia quem defendesse o lado educativo dos quadrinhos, como o sociólogo Gilberto Freyre, argumentando que eles eram acessíveis às massas e, por isso, poderiam ser aproveitados como ferramentas no ensino. No final da década de 1950, tinha entre os títulos mais vendidos as HQs norte-americanas Batman, Zorro, Tarzan e Superman. As publicações com temas religiosos e educativos não traziam lucro, mas também não traziam prejuízo, pois o governo subsidiava o papel utilizado (GONÇALO JUNIOR, 2004).

Sob a mira de investigações, os quadrinhos passaram a ser questionados quanto às representações de personagens femininas nas histórias, mas não com uma discussão sobre igualdade de gênero, mas sim, com a crítica sobre a recorrência de temas ligados ao sexo, expondo personagens sexualizadas. Na década de 1950, a EBAL lançou uma revista de quadrinhos destinada ao público feminino chamada Rosalinda.

Figura 10 - Capa da HQ Rosalinda

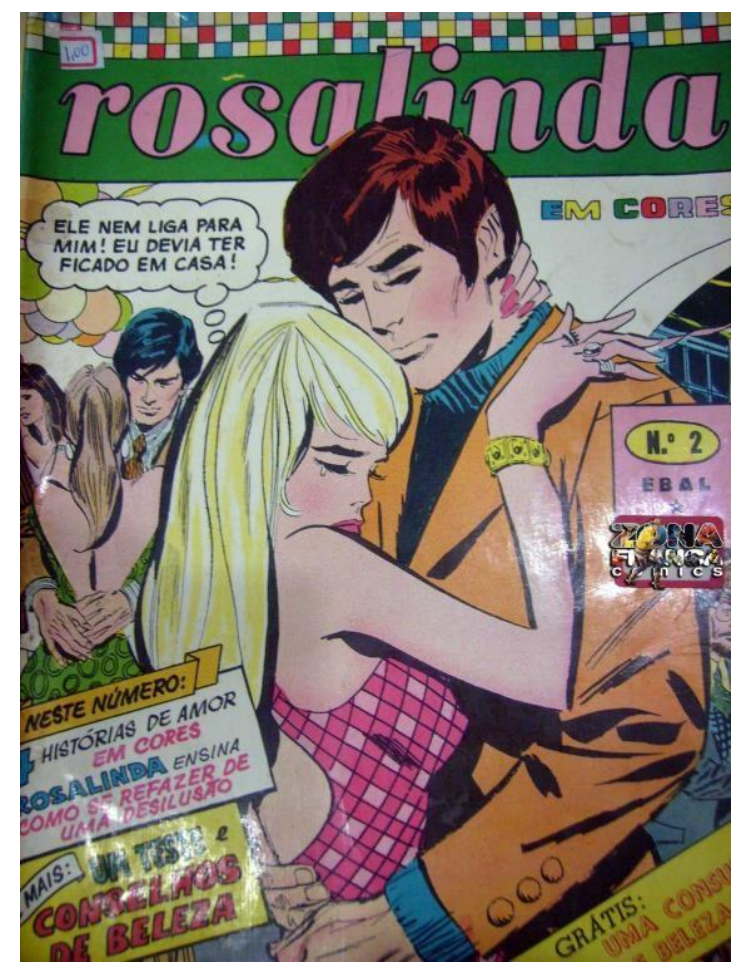

Fonte: http://zonafrancacomics.blogspot.com.br/2011/01/rosalinda-em-cores-editora-ebalyoung.html (2018)

Roberto Marinho se tornou o grande editor de quadrinhos na década de 1950, pois Aizen, seu principal concorrente, passava por dificuldades financeiras há anos. Nessa época, o 
jornalista Carlos Lacerda, do jornal Tribuna da Imprensa, fez ataques aos quadrinhos e à postura de Marinho. Lacerda apontava os apelos sexuais de heroínas como Sheena, a Rainha das Selvas que, segundo ele, eram desenhadas com roupas sensuais para seduzir os leitores.

Figura 11 - Quadro da HQ Sheena

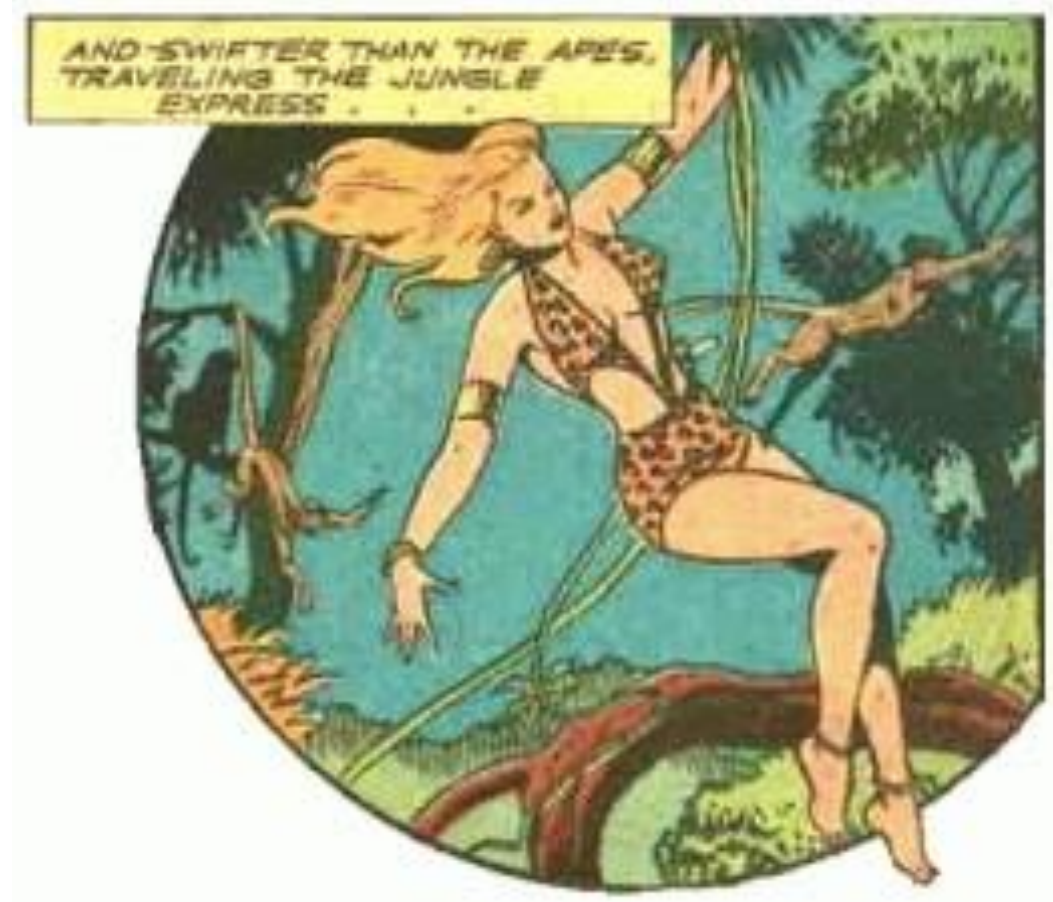

Fonte: http://www.lainsignia.org/2004/julio/cul_067.htm (2018)

Marinho mantinha a tradição, desde os anos 30, de publicar revistas de fofocas, como Radiolândia e Cinelândia, e contos policiais, como a $X-9$ (que trazia a HQ Agente Secreto $X$ 9, de Dashiel Hammet, desenhada por Alex Raymond) e Meia-Noite, pela Editora Rio Gráfica, incorporada à Editora Globo, na década de 1950. Os adversários de Marinho diziam que "ele sabia agradar em especial ao público masculino" e que "inundava as capas e as páginas internas de suas revistas com fotos de garotas de lingerie, maiô ou biquíni, em poses provocantes" (GONÇALO JUNIOR, 2004, p. 300). Curioso notar que, no site da Editora Globo, a revista Meia-Noite, junto com as revistas de fofoca Cinelândia e Radiolândia, são consideradas algumas das "primeiras revistas femininas de sucesso no país", representando "uma participação de 65\% nas publicações da editora" (GLOBO, 2010)

Lacerda tomou como argumento que a crise de 1929, nos Estados Unidos, forçou os desenhistas a buscarem atrativos para as histórias, substituindo os comics de humor por histórias guiadas pela violência (crimes, terror) e pelo "sex appeal". 
O fim da década de 1950 também é marcado pelas publicações eróticas de Carlos Zéfiro (pseudônimo de Alcides Caminha), que se manteve anônimo por mais de trinta anos, publicando seus gibis de modo clandestino no Rio de Janeiro. O autor só revelou a identidade na década de 1990, durante a Primeira Bienal Internacional de Quadrinhos e estima-se que tenha publicado cerca de seiscentos gibis eróticos.

$\mathrm{O}$ anonimato permitia-lhe fazer suas revistas sem nenhum pudor. Muitas vezes, mostrava façanhas sexuais de rapazes bem-dotados com suas primas e cunhadas, vizinhas e desconhecidas, patroas e empregadas. Havia também padres com freiras, padres com padres, freiras com freiras. Algumas vezes, suas histórias de final moralista e abordagem machista caíam para o grotesco, com mulheres que transavam com cachorros e cavalos (GONÇALO JUNIOR, 2004, p. 320).

Embora tenha sido o quadrinista mais procurado pela polícia durante o período da ditadura militar, seus quadrinhos fizeram muito sucesso, tendo, entre seus leitores, policiais envolvidos com as investigações (GONÇALO JUNIOR, 2004). Seus gibis pornográficos ficaram conhecidos como "catecismos" e escandalizaram as famílias e instituições religiosas da época.

Figura 12 - Capa de HQ de Carlos Zéfiro

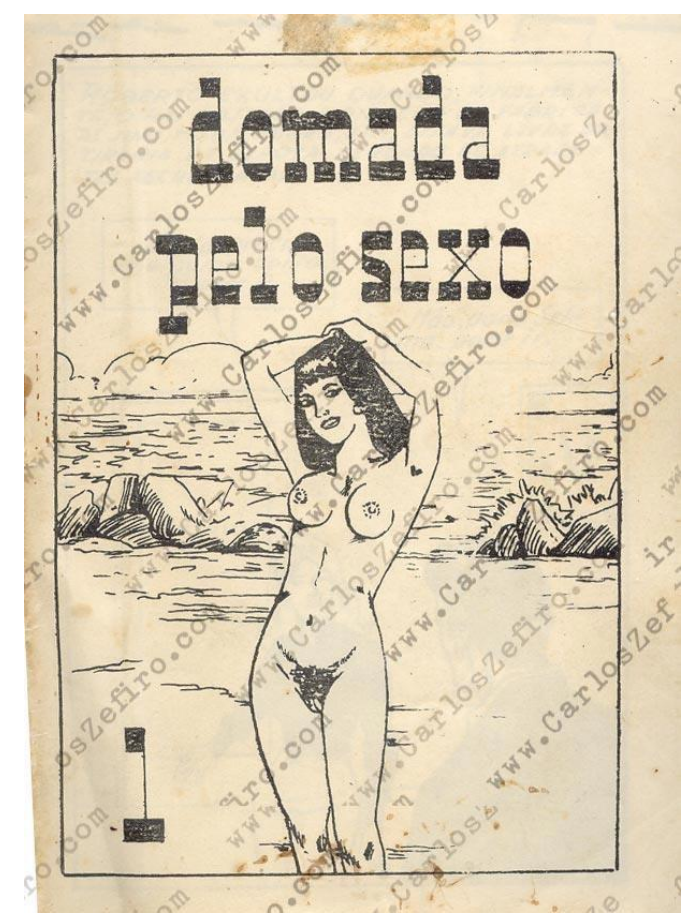

Fonte: http://levaumcasaquinho.blogspot.com.br/2016/10/domada-pelo-sexo-um-catecismoclassico.html (2018) 
$\mathrm{Na}$ década de 1960, os quadrinhos já haviam conquistado espaço definitivo no mercado editorial brasileiro. Aizen recuperou seu protagonismo, a partir da segunda metade da década de 1950, e outros empresários do ramo das comunicações continuaram com interesse pela publicação de HQs, como Victor Civita (Editora Abril) e Assis Chateaubriand (Diários Associados). Aizen, Marinho e Chateaubriand atingiam tiragens "que hoje seriam consideradas espetaculares pelo mercado editorial, quase sempre acima dos 100 mil exemplares por edição" (GONÇALO JUNIOR, 2004, p. 161), graças ao avanço do sistema de transporte de carga, que ampliou a distribuição de quadrinhos pelo país.

A editora Continental, nos anos 1960, passou a ser a editora Outubro, com quadrinistas empenhados em criar personagens genuinamente brasileiros. Um dos militantes pela nacionalização foi o (ainda novato na área) Mauricio de Sousa.

O começo da Outubro foi marcado pelo idealismo e pela descontração dos colaboradores, que dividiam seu tempo entre o trabalho nas revistas e a reestruturação do movimento de nacionalização dos quadrinhos - que ganharia força a partir de 1961 (GONÇALO JUNIOR, 2004, p. 315).

A década de 1970 é marcada pelo lançamento de revistas alternativas, como O Pasquim, Balão e $O$ Bicho. As mulheres atuaram junto a essas publicações como exceções dentro de ambientes dominado por homens e, hoje, o registro de suas obras não é de fácil acesso. Maria Cláudia França Nogueira, conhecida como Crau da Ilha, era uma das poucas mulheres da revista $O$ Bicho e ficou conhecida no meio underground. Preocupada com a falta de representatividade das mulheres quadrinistas no contexto brasileiro, idealizou e editou, em 2013, a revista-livro As Periquitas, com contribuições de diversas artistas. A publicação chegou a ser indicada ao Troféu HQMIX, na categoria Publicação de Humor Gráfico, em 2014. 
Figura 13 - Capa da revista As periquitas

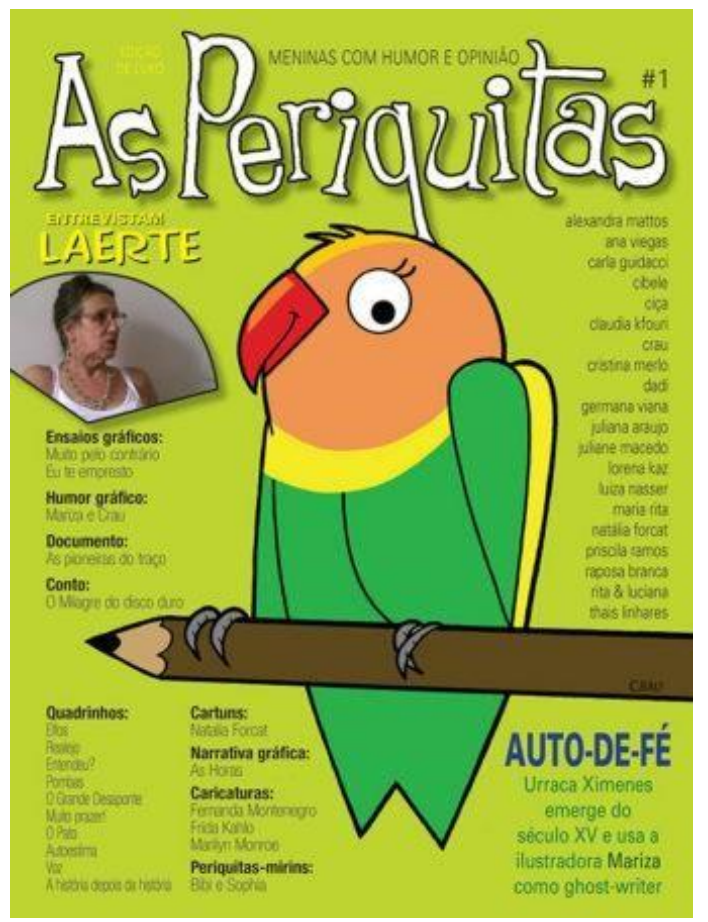

Fonte: http://ladyscomics.com.br/elc/portfolio/crau-da-ilha/

Durante o período da ditadura militar, dois nomes de mulheres se destacam na produção de quadrinhos para a imprensa: Mariza Dias Costa e Ciça. Mariza colaborou com $O$ Pasquim, com a Folha de São Paulo e foi uma das poucas a participarem da revista Chiclete com Banana, publicada pela Circo Editora, que reunia quadrinistas que se tornaram conhecidos na imprensa brasileira, como Glauco, Luiz Gê, Angeli e Laerte. Ciça, criadora da série de tirinhas Pagando o Pato, criticava a situação sociopolítica do país, com personagens animalescos. Apesar de ser considerada uma quadrinista importante d'O Pasquim, a obra de Ciça sequer é citada no documentário O Pasquim - A subversão do humor, 2004, dirigido por Roberto Stefanelli (BOFF, 2014).

Quando o assunto é a formação de leitores - com destaque às leitoras, como é de interesse desta pesquisa - o consumo de gibis está estreitamente ligado a um nome: Mauricio de Sousa, criador da Turma da Mônica. No Brasil, a venda em bancas de jornais ainda predomina, apesar de existiram algumas lojas especializadas nos grandes centros. A formação do público, considerando a presença de leitores e leitoras de quadrinhos, possui uma trajetória particular, de acordo com Vergueiro e Bari (2002).

Os pesquisadores desenvolveram uma análise sistemática do perfil de leitores, por meio de reuniões mensais realizadas no Núcleo de Pesquisa de Histórias em Quadrinhos da Escola de Comunicações e Artes da Escola de Comunicações e Artes da Universidade de São 
Paulo, criado em 1990. Eles apontam que o contato inicial de muitas leitoras ocorreu através da aquisição de publicações da Mauricio de Sousa Produções, responsável pelo gibi da Turma da Mônica.

A pesquisa detectou o perfil do público feminino, que seria composto por "mulheres adultas, escolarizadas e inseridas no mercado de trabalho, cujo consumo tem sido determinante para a sobrevivência dos quadrinhos no país" (VERGUERIO E BARI, 2002. p. 4). Sousa tem atuado na contramão do mercado internacional, cuja prioridade é atingir o público masculino adolescente:

O grande autor e editor brasileiro Mauricio de Sousa, que é hegemônico na produção brasileira, estabeleceu uma tendência local completamente contrária ao que ocorreu no mercado internacional de quadrinhos. Enquanto a produção norte-americana tem dedicado os últimos trinta anos à exploração do público masculino adolescente, através da concentração na temática dos super-heróis, com clara distinção de gênero, eliminando a produção voltada para o público infantil, Sousa tem feito exatamente o contrário, com grande sucesso (VERGUEIRO E BARI, 2002, p. 3).

A personagem Mônica, protagonista da história mais famosa criada por Mauricio de Sousa, fez e ainda faz parte da infância de muitas pessoas, representando uma garota corajosa e de personalidade marcante.

\subsection{Elas por elas no mundo}

A história da atuação feminina nos quadrinhos brasileiros no século XX esteve ligada à imprensa, em que alguns nomes conseguiram destaque com produções de charges, caricaturas e tiras políticas, e ao mercado underground, sobretudo de revistas de HQs. Nesses dois cenários grandes nomes dos quadrinhos na imprensa tradicional foram revelados, como Laerte, Angeli e Glauco, que tiveram reconhecimento na imprensa underground e tradicional. As mulheres atuaram como exceções que "furaram" a bolha e, mesmo assim, não constam em alguns trabalhos que se propõem a fazer uma reconstituição histórica dos quadrinhos no Brasil (BOFF, 2014).

Neste tópico, buscamos referências de autoras de outros países que adquiriram notoriedade, que possam indicar um maior protagonismo das mulheres enquanto criadoras de HQs. O objetivo é traçar caminhos que levaram as quadrinistas brasileiras a atuar no cenário independente no Brasil, como destaca Luyten (2002), assumindo funções que não lhes eram acessíveis no mercado formal, sobretudo através da produção de fanzines.

Destacam-se as personagens dos quadrinhos norte-americanos e europeus, criadas por mulheres, que alcançaram sucesso internacional, o surgimento das graphic novels, a ascensão 
dos quadrinhos franco-belgas e a força do mangá no Brasil. Boff (2014, p. 152) ressalta que poucas mulheres conseguem se destacar internacionalmente, "o que parece ser mais um problema de visibilidade do que de quantidade de mulheres atuantes na área dos quadrinhos".

A autora observa que a inserção da mulher no mercado de quadrinhos foi mais expressiva nos Estados Unidos e Japão, os grandes países produtores de quadrinhos no mundo. Algumas personagens criadas por mulheres fizeram sucesso nos Estados Unidos, como foi mencionado em um dos capítulos anteriores, mas não chegaram ou tiveram pouca repercussão no Brasil.

Na década de 1930 foi criada a Little Lulu pela norte-americana, Marjorie Henderson Buell, que se tornaria uma personagem reconhecida mundialmente. No Brasil, ela ficou conhecida como Luluzinha e a aceitação do público brasileiro pode oferecer pistas sobre como uma personagem criada por uma mulher influenciou na formação de leitores e, posteriormente, serviu de referência para as quadrinistas.

De acordo com Boff (2014, p. 157), "Luluzinha pode ser considerada uma menina inteligente, particularmente mal-humorada e briguenta. Suas características contribuem para a crítica à tradicional família norte-americana da época de seu nascimento", como a questão do casamento, da vida doméstica, fazendo referência às feministas do início do século XX.

O Japão é o país cujo mercado de mangás é permeável à atuação de mulheres quadrinistas, o que é uma profissão apreciada e bem remunerada. "O país tem um amplo número de criadoras de mangá (como são conhecidos os quadrinhos no Japão), as chamadas mangakás, que influenciaram o consumo e produção de quadrinhos pelo público feminino em inúmeros países”, explica Boff (2014, p. 168). O público feminino, inclusive, representa um nicho de mercado atendido pelos mangás do estilo shojo, que seriam mais delicados, ao contrário do estilo shonen, mais violento e voltado para os meninos.

A apropriação de grande parte dos meios de produção, se não significa necessariamente a diminuição de visões estereotipadas sob as mulheres, possibilita visualizar como essas mulheres têm se autorrepresentado nos quadrinhos, já que os intermediários da produção, que poderiam limitar os anseios criativos das artistas, também representam o sexo feminino (BOFF, 2014, p. 169).

Na França da década de 1960, mulheres usavam os quadrinhos para criticar os papéis tradicionais atribuídos pelas mulheres, num viés feminista, como Chantal Montelier, Heléne Bruller e Claire Bretécher, esta última, com grande repercussão no cenário europeu, o que acabou influenciando autoras latinas. Apesar de ser pouco conhecida no Brasil, Bretécher conseguiu notoriedade com a efervescência contracultural da época, usando os quadrinhos 
para afirmar seu posicionamento político feminista. De acordo com Boff (2014, p. 174), “uma de suas principais criações é a personagem Cellulite, apresentada na revista Pilote, de significativa importância na França. Em 1960, Bretécher publicou na revista Tintin”. Ela é criadora da série Les frustés (Os frustrados) e tinha uma editora, a Éditions du Fromage com Marcel Gotlib e Nikita Mandyka.

A iraniana Marjane Satrapi teve seu trabalho "Persépolis" publicado e premiado em diversos países e, inclusive, foi feito um filme de animação baseado na graphic novel, que concorreu à Palma de Ouro no Festival de Cannes, em 2007. Com uma narrativa autobiográfica, ela discute questões culturais e políticas do Irã ao mesmo tempo em que conta sobre a própria infância e adolescência.

Sua principal obra apresenta uma atmosfera de desmistificação das identidades femininas em países nos quais o fundamentalismo religioso está presente, conduzindo as ações do estado e das instituições. Também apresenta algumas maneiras que algumas mulheres encontraram, no Irã, para se movimentar dentro da cultura opressiva (BOFF, 2014, p. 180).

A argentina Maitena, autora de "Mulheres alteradas" também conseguiu sucesso internacional narrando situações enfrentadas por mulheres, de forma bem-humorada. "A obra de Maitena apresenta temáticas como a moda, o corpo, a família, os filhos, os relacionamentos" (BOFF, 2014, p. 182), temas recorrentes ligados à personagens femininas dos quadrinhos mainstream, só que na perspectiva de uma mulher, o que não impede que elas tenham traços estereotipados. "Mas se Maitena nem sempre propõe novos modos de ver o feminino, seu sucesso no campo dos quadrinhos certamente estimula a inserção de outras mulheres nesse mercado", reflete Boff (2014, p. 184).

Os quadrinistas independentes no Brasil receberam influência de vários países, "inicialmente das revistas humorísticas infantis europeias e das revistas em quadrinhos norteamericanas, mais recentemente dos mangás”, como explica (MEDEIROS, 2016, p. 55). Os fãs começaram a se organizar em torno de uma expressão conhecida como fanzine, que permite observar as interações entre as publicações e a recepção do público.

O fanzine, que surgiu nos Estados Unidos, na década de 1930, reúne fãs em torno de interesses em comum, para compartilharem conhecimentos, críticas e incentivos para que deem continuidade às próprias publicações. Por muito tempo, a circulação de fanzines ficou restrita à comunidade de fãs que dialogavam entre si. Com a internet e eventos destinados às publicações independentes, sobretudo nos grandes centros urbanos, alterou essa dinâmica no século XXI, permitindo que outros tipos de produção fossem criados, nem sempre com a relação de fã envolvida. 
O quadrinho independente é definido não tanto como uma revista que está na contramão do mercado convencional pelo conteúdo temático e expressivo, mas principalmente pelo modo como elas encaram o mercado. Analisando as publicações independentes percebemos que são revistas com baixas tiragens, publicadas por editoras pequenas, coletivos ou autores individuais, de distribuição restrita, abrangendo uma grande variedade de temáticas e gêneros e que sua grande vantagem em relação as publicações das grandes editoras é que os artistas podem manter o domínio sobre suas obras, sem se sujeitar a um editor (MEDEIROS, 2016, p. 86).

Historicamente, a imprensa e as grandes editoras de HQs não investiram de maneira igualitária em produções criadas por autores e autoras (CHENAULT, 2007). Entre as editoras menores, chamadas de independentes, parece haver uma maior preocupação em vender HQs de autoria feminina e o investimento focado em quadrinhos produzidos no Brasil.

$\mathrm{Na}$ reportagem intitulada "Com cena independente e interesse de editoras, HQs se fortalecem no Brasil" (CASARIN, 2015) é feito um panorama das editoras que trabalham com HQs nacionais, com opiniões de especialistas sobre o novo momento vivido pelo mercado. "Os quadrinhos estão em alta. Voltou a ser cult, ninguém mais tem vergonha de ser nerd", opina o entrevistado Sidney Gusman, editor do site Universo HQ e o responsável pelo planejamento editorial da Mauricio de Sousa Produções. Outro entrevistado é Érico Assis, jornalista e especialista em tradução de quadrinhos. Ele menciona a importância das graphic novels para a entrada dos quadrinhos nas livrarias: "Nos últimos dez anos, vimos a seção de quadrinhos nas livrarias crescer ou brotar com espaço considerável, passamos de quase zero a dezenas de graphic novels nacionais por ano".

Para Bibiana Leme, editora do selo Barricada, que faz parte da editora Boitempo, o interesse pelas graphic novels é "firmar no mercado, conquistar leitores que já consomem quadrinhos e também apresentar essa linguagem para a parte do nosso público habitual que ainda não estiver acostumada a ela". Outras editoras mencionadas na reportagem, que compartilham objetivos semelhantes, são: Nemo (Selo do Grupo Autêntica), Mino, Veneta e Quadrinhos na Cia (faz parte da Companhia das Letras e, apesar de ser uma grande editora, também destina parte do investimento em obras de mulheres).

Efetuou-se o levantamento de HQs, nacionais e estrangeiras, publicadas por editoras independentes no Brasil e distribuídas em livrarias, a fim de localizar as obras de autoria feminina. Foram consideradas tanto HQs de autoria feminina exclusiva quanto dividida com quadrinistas homens, considerando que tarefas como roteiro e ilustração são igualmente relevantes para a elaboração da narrativa em quadrinhos. Ao todo, foram levantadas 357 HQs publicadas por cinco editoras: Barricada, Nemo, Veneta, Mino e Quadrinhos na Cia. 
Dentre as obras publicadas, 73 foram identificadas com autoria feminina exclusiva (51) ou partilhada (22), o que corresponde a cerca de 20,6\% do universo. As obras foram categorizadas nos gêneros "ficção" (o que inclui adaptações literárias de obras ficcionais) e "não ficção" (autobiografias, biografias e enredos baseados em pesquisa histórica), conforme foram apresentadas nas sinopses disponibilizadas nos sites das editoras.

$\mathrm{Na}$ categoria ficção foram contabilizadas $34 \mathrm{HQs}$, com a ressalva de que 13 delas foram publicadas como séries de 4 autoras pela editora Nemo: Nancy Osa publicou a série da franquia Minecraft em 4 volumes; Fernanda Nia publicou "Como eu realmente" em 2 volumes; Paula Pimenta publicou "Fazendo o meu filme" em 3 volumes; Bianca Pinheiro publicou Bear em 3 volumes.

$\mathrm{Na}$ categoria de não ficção foram contabilizadas $39 \mathrm{HQs}$ com a ressalva de que “Persépolis", de Marjani Satrapi, foi dividida em 4 volumes pela Quadrinhos na Cia. Dentre as 39, 26 são apresentadas como autobiografia, 5 como histórias baseadas em pesquisa histórica e 8 são biografias de personalidades, de acordo com as descrições encontradas nos sites das editoras.

Quadro 1 - Editoras e publicações de autoria feminina por tipo

\begin{tabular}{|c|c|c|c|}
\hline EDITORAS/SELOS & $\begin{array}{c}\text { TOTAL DE } \\
\text { PUBLICAÇÕES }\end{array}$ & $\begin{array}{c}\text { FICÇÃO DE } \\
\text { AUTORIA FEMININA }\end{array}$ & $\begin{array}{c}\text { NÃO-FICÇÃO DE } \\
\text { AUTORIA FEMININA }\end{array}$ \\
\hline BARRICADA & 7 & 1 & 2 \\
\hline NEMO & 140 & 24 [13 séries -4 autoras] & 17 \\
\hline VENETA & 58 & 4 & 7 \\
\hline MINO & 40 & 2 & 0 \\
\hline $\begin{array}{l}\text { QUADRINHOS NA } \\
\text { CIA }\end{array}$ & 112 & 3 & 13 \\
\hline TOTAL & 357 & 34 & 39 \\
\hline
\end{tabular}

Fonte: A autora (2018).

O selo Barricada foi criado em 2014 como uma extensão da editora Boitempo especializada em quadrinhos nacionais e internacionais "libertários, de resistência, que se destacam inovando o cenário independente de quadrinhos" (site). A curadoria é feita por Luiz Gê, Ronaldo Bressane e Gilberto Maringoni. Três dos sete títulos lançados são de autoria 
feminina e dois são histórias de não-ficção. A Barricada publicou 3 volumes da Coletânea Cânone Gráfico, que reúne clássicos dos quadrinhos e graphic novels.

A editora Veneta teve o primeiro título publicado em 2012 com a "responsabilidade social desafiar convenções, os consensos manufaturados, as autoridades em geral e, se necessário, seus leitores", de acordo com a descrição presente na homepage do site. Já foram publicados 58 títulos e metade deles são nacionais. Dentre os 58, 11 são de autoria de mulheres ou parcerias. A maioria pode ser descrita como não ficção (7) e nota-se que penas 3 são de autoria exclusiva de mulheres. A Veneta publica quadrinhos adultos, no formato de graphic novel, em geral.

O selo Nemo faz parte do Grupo Autêntica desde 2011 e, no início, tinha como proposta publicar obras de quadrinistas renomados, como Moebius e Flávio Colin. Com o tempo, declaram ver a necessidade de valorizar a produção feminina propondo "combater o preconceito existente no segmento". A ideia é "mostrar que, mais do que nunca, as mulheres têm produzido quadrinhos de qualidade no mundo todo". A Nemo foi a única editora levantada que explicita essa preocupação com o trabalho feminino e reconhece um desequilíbrio histórico.

Foram publicados 140 títulos, em um catálogo diversificado em termos de gênero e formato, incluindo graphic novels, gibis de mangás, HQs vinculadas à franquia Minecraft (um jogo infantil), HQs infantis e adaptações de clássico de Shakespeare. Das 140 publicações, 41 são de mulheres ou parcerias e 35 de HQs nacionais. Dentre os títulos nacionais, 14 são de mulheres, o que se aproxima da paridade. A maioria dos quadrinhos de autoria feminina pode ser considerada ficcional (24), mas é preciso fazer a ressalva de que 13 títulos correspondem a séries (como a da franquia Minecraft) elaboradas por 4 autoras. As demais obras (17) são de não ficção.

Os destaques são para obras autobiográficas que envolvem temas ligados à gênero e sexualidade (como Justin, de Gauthier, e Vírus Tropical, de Power Paola) e misoginia (como em Desconstruindo Una, de Una). O selo declara no site oficial a necessidade de publicar "graphic novels com temáticas de relevância, como questão de gênero, abuso sexual, misoginia e responsabilidade social para o Brasil". Inclusive, duas autoras que fazem parte da amostra de pesquisa, Bianca Pinheiro e Fernanda Nia, tiveram suas webcomics publicadas pelo selo.

A editora independente Mino foi lançada em 2014, com o objetivo de "publicar quadrinhos autorais que tenham em comum uma personalidade marcante". Ao todo, são 40 títulos publicados e 2 de autoria feminina. Bianca Pinheiro aparece novamente com a 
publicação de "Dora"; a segunda autora é Janaina de Luna (editora-chefe da Mino) que, junto com Pedro Cobiaco, publicou Cais, ambas ficcionais.

O selo Quadrinhos na Cia. foi criado em 2009, como parte da editora Companhia das Letras. O selo publicou as premiadas obras Persépolis, da iraniana Marjani Satrapi, entre outros títulos da mesma autora, e Fun Home, de Alison Bechdel. Dentre as 112 publicações (a maioria graphic novels), 16 são de mulheres ou parcerias. Dentre eles, 13 podem ser considerados de não ficção. 


\section{QUADRINHOS NA INTERNET}

$\mathrm{Na}$ internet, surgem novas personagens femininas a cada dia, no universo da produção independente de quadrinhos. Se, historicamente, o mercado editorial silenciou ou não ofereceu oportunidades para profissionais mulheres, as publicações em blogs, sites e páginas nas redes sociais têm crescido, revelando autoras de várias partes do Brasil. Alguns quadrinhos criados por mulheres e publicados online, que alcançaram prestígio dentro e fora das redes sociais (com o reconhecimento de veículos jornalísticos e do circuito de premiações, por exemplo) podem ser citados, como: Garota Siririca, série de Gabriela Masson, que usa o pseudônimo Lolove6; Lizzie Bordello e as Piratas do Espaço, série de Germana Viana e Bear, de Bianca Pinheiro, quem também publicou pela série Graphic MSP. As três HQs possuem protagonistas femininas e foram publicadas em sites, de modo que os leitores e leitoras pudessem acompanhar o desenvolvimento das personagens a partir de atualizações semanais

Figura 14 - Página da HQ Garota Siririca

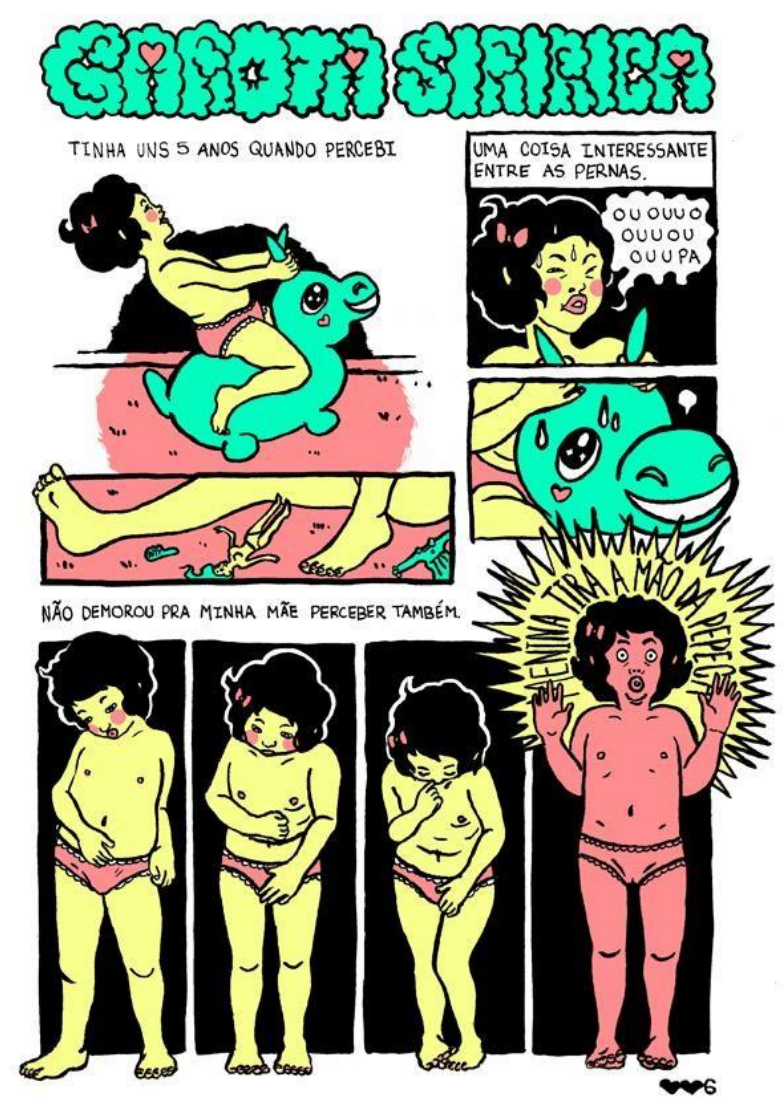

Fonte: http://revistasamba.blogspot.com.br/2013/08/garota-siririca-3.html (2013) 
Figura 15 - Página da HQ Lizzie Bordello e as Piratas do Espaço

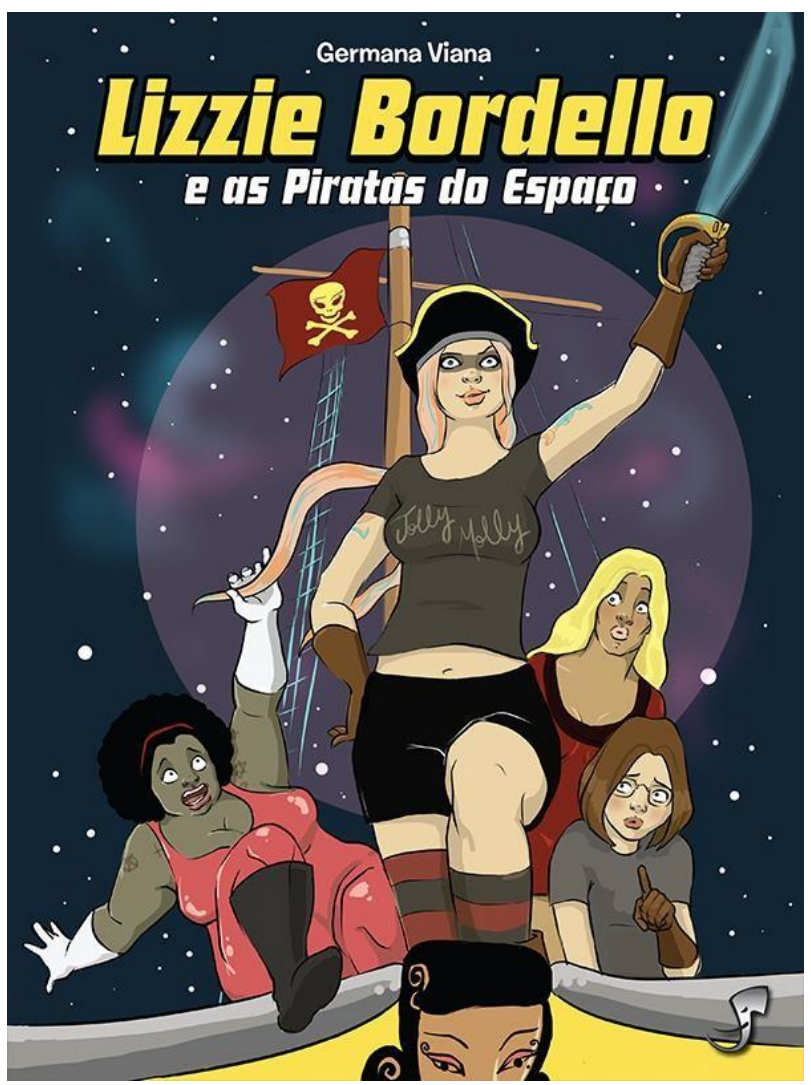

Fonte: http://jamboeditora.com.br/produto/lizzie-bordello-e-piratas-espaco/

Figura 16 - Desenho da HQ Bear

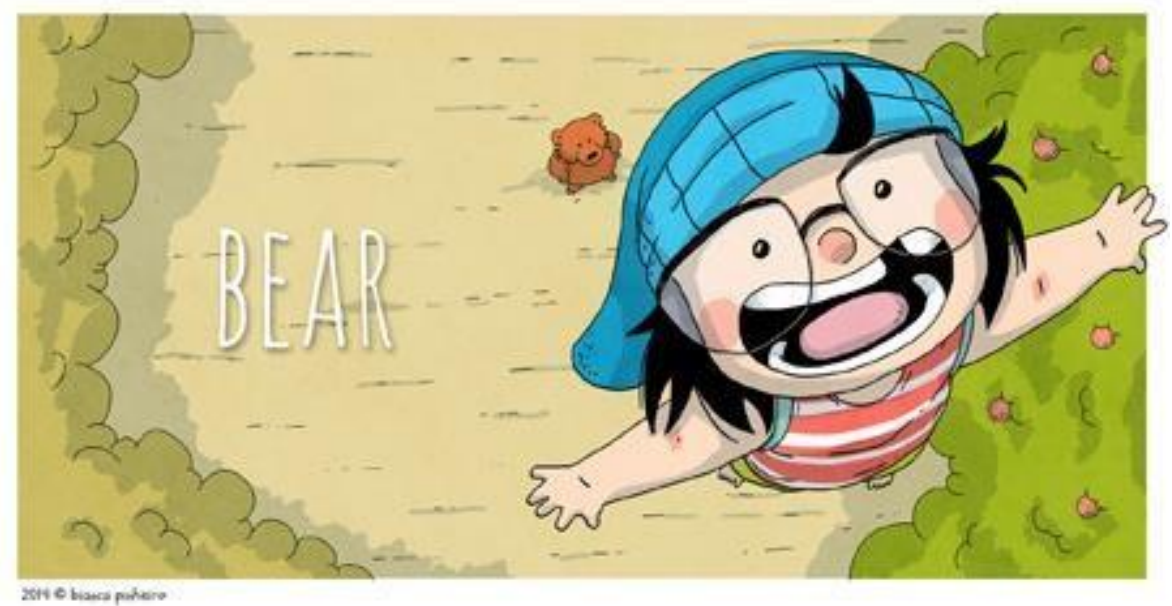

Fonte: http://bear-pt.tumblr.com/

Publicar na internet envolve algumas vantagens como redução dos custos de produção e divulgação e a possibilidade de acompanhar eventos em tempo real, o que é interessante para autoras que trabalham com tiras, cartuns e charges, por exemplo, e que dialogam com acontecimentos noticiados pela mídia. 
Abrecht (2012) comenta que milhares de quadrinhos têm sido publicados na internet, mas, ao mesmo tempo em que é fácil acessá-los, é difícil encontrar aquilo que dialoga com os próprios interesses. $\mathrm{O}$ que vai ser mostrado ou não a um usuário que procura por quadrinhos online, ainda depende de instâncias que legitimem e divulguem o trabalho, que garantam maior repercussão nas ferramentas de busca e nas redes sociais. Isso se apresenta como um entrave para a disseminação da produção feminina, já que o nicho de público nerd e geek representa majoritariamente os interesses masculinos:

Dentro da comunidade geek / nerd, onde os homens são comumente vistos como o centro, encontra-se espaço para discussão de masculinidades alternativas. No entanto, enquanto existem espaços que aceitam as masculinidades alternativas, também existem espaços confortáveis para que os homens defendam os interesses masculinos. Por mais que seja um lugar aceitável para as masculinidades alternativas, a cultura nerd também fetichiza narrativas da masculinidade normativa, com base na força de heróis de quadrinhos e sexualização dos corpos femininos (ABRECHT, 2012, p. 37, tradução nossa).

As mulheres estão buscando alternativas à indústria dos quadrinhos e reivindicando espaço, se articulando em torno de interesses comuns. É possível que a internet e as redes sociais tenham se tornado ferramentas fundamentais nesse processo e é disso que trataremos nos próximos capítulos.

As mulheres sempre leram quadrinhos, apesar das produções serem, em grande parte, feitas por homens e voltadas ao público masculino, perpetuando um olhar sexista sobre as representações femininas. Por que o discurso masculino acerca do que é ser mulher dominou o mercado editorial de quadrinhos? O que legitima esse discurso? Primeiramente, é preciso ponderar que a centralidade masculina está presente nas produções de cultura de massa, em geral, e o caso das HQs é apenas um reflexo desse padrão.

Foucault, ao longo de sua obra, lançou-se na tentativa de analisar de que modo "as grandes estratégias de poder se incrustam, encontram suas condições de exercício em microrelações de poder" (FOUCAULT, 1979, p. 249). Ele observa que os discursos filosóficos, artísticos, religiosos, políticos e científicos obedecem às regras de uma espécie de "polícia discursiva" (FOUCAULT, 2009, p. 34), que atesta quais vozes do discurso são ou não qualificadas. Esse processo não é homogêneo para todos os tipos de discurso, pois, "nem todas as regiões do discurso são igualmente penetráveis; algumas são altamente proibidas (diferenciadas e diferenciantes), enquanto outras parecem quase abertas a todos os ventos e postas, sem restrição prévia” (FOUCAULT, 2009, p. 35).

O conceito de sexualidade ganhou força no século XIX e, de modo geral, está ligado ao modo como um indivíduo se reconhece como sujeito, dentro de um sistema social: 
Em suma, tratava-se de ver de que maneira, nas sociedades ocidentais modernas, constitui-se uma "experiência" tal, que os indivíduos são levados a reconhecer-se como sujeitos de uma "sexualidade" que abre para campos de conhecimento bastante diversos, e que se articula num sistema de regras e coerções. (FOUCAULT, 1985, p. 10).

Ao longo do século XX, a temática da sexualidade emergiu do domínio do privado para a discussão pública, a partir das reivindicações do movimento feminista que se articulou em várias frentes, incluindo o espaço acadêmico e o das artes. $\mathrm{O}$ corpo se torna, simultaneamente, "lugar de opressão e de resistência e, por outro lado, da continuada relevância da afirmação que o feminismo vem reivindicando ao longo de sucessivas gerações, de que 'o privado é político"” (MACEDO, 2006, p. 64).

Nesse processo de diversificação das experiências em rede, uma questão veio à tona, movendo o circuito de produção de quadrinhos no Brasil: a falta da atuação feminina, seja no plano do consumo quanto no plano da criação. Mas será que elas, de fato, não leem e não fazem quadrinhos?

Uma questão presente na literatura que envolve a representação do feminino nos quadrinhos é a função de objeto do olhar masculino, sua representação elaborada pela maioria de autores homens presentes no mercado editorial. Pouco se fala da mulher enquanto autora de HQs, o que pode sinalizar tanto um silenciamento de suas produções quanto a falta de oportunidades profissionais.

Barcellos (2001) considera que a representação da mulher nas histórias em quadrinhos são projeções, muitas vezes idealizadas e estereotipadas, a partir daquilo que os roteiristas e desenhistas (na maioria homens) imaginam sobre o feminino. Há uma tendência de homogeneização dos produtos da indústria cultural que faz com que os autores reproduzam valores que acreditam estarem em consonância com os anseios dos leitores, reproduzindo uma relação paternalista para maior aceitação dentro do mercado.

HQs que passam por processo de digitalização ou que são produzidas integralmente a partir das ferramentas digitais e publicadas online, lidam com uma série de nomenclaturas, parecendo não haver consenso entre os estudiosos de quadrinhos sobre qual o melhor termo a ser utilizado. Neste capítulo, busca-se levantar as principais discussões acerca das HQs no universo digital, com o objetivo de optar pelo conceito que melhor se aplica a esta pesquisa. No primeiro momento, foi necessário levantar as principais classificações de gênero e formato que foram consagradas no mercado impresso, para, então, refletir sobre as mudanças trazidas pela tecnologia digital. 
Algumas nomenclaturas são associadas à narrativa dos quadrinhos, entre elas, charges, cartuns e tiras (ou "tirinhas"). Ramos (2009), em uma abordagem linguística que se apropria da reflexão sobre os gêneros literários, classifica as histórias em quadrinhos como hipergênero, que funciona como "um grande rótulo, que agregaria diferentes gêneros comuns" (RAMOS, 2009, p. 362). As características que unem os diferentes gêneros seriam a narrativa sequencial e utilização de recursos gráficos da linguagem dos quadrinhos, como os balões.

Ramos (2009, p. 365) observa que diversos fatores influenciam na definição das nomenclaturas dos gêneros como "a intenção do autor, a forma como a história é rotulada pela editora que a publica, a maneira como a trama será recebida pelo leitor, o nome com o qual o gênero foi popularizado e que tornou o gênero mais conhecido junto ao público". A despeito destas variáveis, o autor sintetiza as principais características dos gêneros cartum, charge, tiras cômicas e tiras seriadas, fazendo a ressalva de que não são os únicos possíveis.

Dentro do conceito de hipergênero estariam agregados os "cartuns, as charges, as tiras cômicas, as tiras cômicas seriadas, as tiras seriadas e os vários modos de produção das histórias em quadrinhos" (RAMOS, 2009, p. 362). Esses gêneros teriam elementos comuns, que são: "predominância da sequência narrativa, representada em um ou mais quadros, e uso da linguagem gráfica das histórias em quadrinhos (como os balões)" (RAMOS, 2009, p. 362). Tais elementos ajudam o leitor a identificar que a leitura está ligada à narrativa dos quadrinhos.

O mesmo autor aponta as seguintes características dos gêneros levantados: 1) “charges" (textos de humor que remetem à alguma informação veiculada pelo noticiário); 2) "tiras cômicas" (texto curto inserido em um ou mais quadros, geralmente, em formato retangular e narrativa com desfecho inusitado); 3) "tiras seriadas" ou "tiras de aventura" (assemelham-se às tiras cômicas em termos visuais, mas são partes narradas de uma história maior) e 4) "história em quadrinhos mais longa" (publicadas em suportes que permitem uma narrativa mais detalhada, como as revistas, os álbuns e páginas dominicais, que seriam quadrinhos de uma página publicados nos jornais).

Com a popularização do computador pessoal e da internet novos suportes passaram a compor o universo das publicações de histórias em quadrinhos, facilitando o acesso à arte sequencial com a digitalização de HQs originalmente impressas ou produção de histórias feitas para o ambiente digital. Vergueiro e Sá (2015) abordam a migração dos quadrinhos impressos para o suporte digital e as possibilidades oferecidas aos autores, sobretudo os que não veiculam seus trabalhos em grandes editoras. Antes da internet "todo o processo de criação e produção de HQs estava intimamente ligado à veiculação em seu suporte 
tradicional, o papel", ou seja, o quadrinista se restringia aos custos previstos de impressão (VERGUEIRO e SÁ, 2015, p. 82).

De um processo artesanal, os autores passaram a incorporar técnicas de colorização e letreiramento digital, até a chegada das publicações pensadas para a leitura no computador, como é o caso das HQ-ROMs (quadrinhos vendidos em CD-ROMs que podiam agregar recursos de interatividade) e as HQs publicadas online.

Na literatura é possível encontrar muitos nomes para as HQs disponibilizadas online, como "netcomics", "webcomis" e "HQtrônicas". Vergueiro e Sá (2015) consideram que o termo "webcomics" define os quadrinhos pensados desde o início para a publicação na internet:

Vale ressaltar que um webcomic não é um quadrinho digitalizado, mas geralmente nascem na Internet e nele continuam. Webcartunistas tendem a manter contato uns com os outros, executando trabalhos conjuntos, manter os links outros criadores em suas páginas e, com certa regularidade, colaborar com a obra dos companheiros com as "guest strips" ou "guest comics", ou seja, tiras ou páginas de quadrinhos inteiras feitas como convidados (VERGUEIRO E SÁ, 2015, p. 92).

De acordo com Vergueiro e Sá (2015, p. 91) as webcomics permitem “inovações estéticas e narrativas a serem exploradas pelos artistas, assim como novas formas de fruição por parte do público, com a introdução de maneiras diversas de interação do leitor com a narrativa sequencial". Para Neves, Christino e Ramos (2014, p. 26) a interação entre produtores e consumidores indica que "estão aprovando a ideia de participação coletiva e, assim, expandindo o universo ficcional das histórias em quadrinhos por meio de experiências sensoriais e dialéticas, provocadas pelas novas tecnologias".

A produção de quadrinhos que envolve utilização de recursos digitais se tornou popular durante a década de 1990. Processos como colorização, letreiramento e finalização foram digitalizados dentro de grandes editoras, por conta das vantagens em termos de custo e tempo de produção. Muitos quadrinistas utilizam equipamentos (como tablets e mesas digitalizadoras) e softwares de edição de imagens, substituindo processos artesanais de desenho sobre papel (KRENING, SILVA E SILVA, 2015).

A introdução de técnicas digitais na produção de HQs tornou possível a criação de produtos inovadores, como os HQ-ROMs, que eram histórias em quadrinhos com características semelhantes aos games. Elas atraíram a atenção dos leitores de quadrinhos na década de 1990, mas, obstáculos na produção e distribuição fizeram com que os investimentos nesse tipo de material fossem abandonados. No mercado editorial impresso, a adoção de 
técnicas digitais possibilitou inovações estéticas e vantagens em termos de custo/tempo de produção, mas não mudanças estruturais nos formatos e modos de narrar as HQs.

A chegada da internet e das plataformas de conteúdo online provocou grande impacto na indústria de quadrinhos, uma vez que surgiram inúmeras formas de publicação sem a necessidade de mediação de uma editora. Com isso, houve "uma grande profusão de publicação de histórias em quadrinhos on-line (sic), em diversos formatos e suportes", permitindo que autores publicassem e divulgassem seus trabalhos gratuitamente na rede (KRENING, SILVA E SILVA, 2015, p. 38).

O leitor de quadrinhos, por sua vez, pode ter acesso a HQs de diversas partes do mundo a custos reduzidos além de poder comprar revistas impressas sem sair de casa. Vergueiro e Sá (2015) discutem sobre a migração de suportes para histórias em quadrinhos, desde o impresso até a internet, além de refletirem sobre as mudanças no mercado editorial trazidas pela tecnologia digital. Enquanto Vergueiro e Sá (2015) tratam de aspectos contextuais, Franco (2002) detalha a hibridização da linguagem das HQs com a introdução dos recursos digitais, classificando sete principais elementos que foram agregados aos quadrinhos impressos: “Animação, Diagramação Dinâmica, Trilha Sonora, Efeitos de Som, Tela Infinita, Narrativa Multilinear e Interatividade” (FRANCO, 2002, p. 6).

Os artigos selecionados trazem definições diferentes para o conceito de histórias em quadrinhos inseridas no ambiente digital. Vergueiro e Sá (2015) definem que o termo mais adequado seria "webcomics", enquanto Franco (2002) utiliza o termo "HQtrônicas", que é uma tradução do inglês "Eletronic Comics".

Vergueiro e Sá (2015, p. 92) adotam o termo "webcomic" para falarem de quadrinhos que "nascem na Internet e nela continuam". Os autores fazem a ressalva de que webcomics não são apenas quadrinhos feitos em papel e digitalizados posteriormente; eles são feitos para serem publicados on-line, ou seja, o(a) autor(a) deve se preocupar com as dimensões da tela e a área útil dos navegadores e, em alguns casos, com os recursos multimídia que podem ser aplicados às HQs. Outra diferença que envolve o universo das webcomics é a rede colaborativa que os (as) quadrinistas tendem a manter para estabelecerem "contato uns com os outros, executando trabalhos conjuntos, manter os links outros criadores em suas páginas e, com certa regularidade, colaborar com a obra dos companheiros" (VERGUEIRO E SÁ, 2015, p. 92).

Franco (2002, p. 17) menciona que vários termos são utilizados para designar histórias em quadrinhos na internet, como "HQ interativa", "Quadrinhos Online", "HQnet" e "Digibi". Ele defende que tais termos não são adequados, pois nem todas as HQs inseridas no ambiente 
digital possuem recursos de interatividade, por exemplo, e nem todas são publicadas online, a exemplo das HQ-ROMs, que eram CD-ROMs vendidos em bancas de jornal, populares durante a década de 90 e que traziam HQs com recursos de interatividade semelhantes a games.

Por esses motivos, ele sugere o neologismo "HQtrônicas", que é uma tradução de "Eletronic Comics", com a substituição da palavra "Comics" (que se refere a um estilo específico de quadrinhos desenvolvidos nos Estados Unidos) por HQ, em português. Franco (2002, p. 18) destaca que a essência desse tipo de produto é a hibridização de linguagens e inclui "um (ou mais) dos códigos da linguagem tradicional das HQs no suporte papel (como a onomatopeia, o balão de fala etc.) com uma (ou mais) das novas possibilidades abertas pela hipermídia”. Ele descreve sete possibilidades de se agregar recursos digitais às HQs, que são: “Animação, Diagramação Dinâmica, Trilha Sonora, Efeitos Sonoros, Tela Infinita, Narrativa Multilinear e Interatividade".

A "Animação" pode aparecer em quatro situações: "animação de um dos quadrinhos da página/cena, objeto animado que se sobrepõe à página/cena, sequência animada paralela à narrativa principal e ainda animação do enquadramento" (FRANCO, 2002, p. 7).

A "Diagramação Dinâmica" provoca o efeito de movimento nos quadros ou faz com que eles "surjam" na tela, conforme o leitor navegue pela HQ.

A “Trilha Sonora" é a adição de músicas que acompanham a leitura, enquanto os "Efeitos Sonoros" são incorporados em momentos específicos da história, substituindo as onomatopeias.

O recurso da "Tela Infinita" permite que a HQ seja planejada sem os limites impostos pelas dimensões do suporte de papel, em que o leitor vai rolando a barra lateral (vertical ou horizontalmente) para continuar a história.

A "Narrativa Multilinear" é possibilitada pelo recurso de hipertexto, “apresentando narrativas com bifurcações ao longo dos caminhos e links paralelos que levam o leitor a sites de assuntos correlatos aos tratados no roteiro da história” (FRANCO, 2002. p.14).

Por fim, o autor define como "Interatividade" o recurso narrativo em que o leitor, pelas suas ações, pode adicionar elementos como os citados anteriormente à história e escolher caminhos paralelos ao enredo principal. Em um nível mais avançado, ele "têm a possibilidade de contribuir com a narrativa criando uma das páginas ou capítulos da história, participando efetivamente como cocriador de uma obra coletiva" (FRANCO, 2002, p. 16). 
Na definição de "HQtrônicas" também são excluídas HQs originalmente analógicas que passam por processo de digitalização, sem conter nenhum dos sete recursos mencionados pelo autor.

Em resumo, o artigo elaborado por Sá e Vergueiro (2015) aborda aspectos contextuais sobre a introdução dos recursos digitais às HQs, incluindo as mudanças no processo produtivo e na circulação dentro do mercado editorial. Adomos o termo "webcomics", que agrega discussões sobre as possibilidades trazidas pela publicação on-line e como isso afetou a forma pela qual os(as) autores(as) de quadrinhos estabelecem contato e parcerias uns com os outros.

\subsection{Produção e distribuição de HQs online}

Softwares possibilitam aplicar vários recursos estéticos aos desenhos, ligados às cores, texturas, efeitos 3D, sobreposição de imagens, entre outros. É comum que as ilustrações sejam feitas de modo artesanal, desenhadas em papel, e depois escaneadas para serem finalizadas e colorizadas com uso de programas específicos. A partir do momento que a imagem é digitalizada, ela passa a ser interpretada pelo computador como um código numérico e "é de se pensar que muitas das histórias em quadrinhos analógicas de hoje têm um vínculo com o digital" (CAPELLARI, 2010, p. 227). Na literatura revisada, os autores tendem a não considerar esse tipo de material dentro do conceito de webcomic (SÁ e VERGUEIRO, 2015). ou de HQtrônica (FRANCO, 2002).

Capellari (2010) aponta duas situações em que as HQs podem chegar à internet:

Uma história em quadrinhos pode chegar à Internet basicamente de duas maneiras: sendo transferida de um meio analógico para o computador, ou sendo produzida diretamente em softwares de desenho gráfico. Por meio do primeiro modo podem ser colocadas no ciberespaço tanto histórias próprias de autores amadores quanto cópias de obras de outros artistas feitas com ou sem autorização. A segunda forma consiste na criação de obra próprias, feitas especialmente para a web contendo ou não efeitos especiais (CAPELLARI, 2010, p. 228).

A partir do momento em que a imagem está no computador, ela pode ser publicada em um blog ou website e agregar recursos como som e movimento, sem que a forma tradicional de narrativa em sequência seja alterada. Além disso, os quadrinistas podem compartilhar seus trabalhos nas redes sociais e divulgá-los sem a necessidade de mediação, no contexto da "era da convergência" explorada por Jenkins (2008). Essa convergência dos meios de comunicação, proporcionada pelo avanço da internet e das mídias digitais, vem mudando

profundamente os modos de socialização, promovendo o que se chama de "cultura participativa e inteligência coletiva" (JENKINS, 2008, p. 27). 
Capellari (2010) comenta sobre as transformações na difusão de HQs com a popularização da internet, destacando a existência de projetos coletivos de divulgação:

Além das publicações convencionais, o universo de quadrinhos para leitura no computador permite também a difusão de histórias alternativas, que não encontraram espaço no mercado editorial. Essas narrativas podem estar em sites individuais dos autores ou em páginas coletivas destinadas a ajudar novos talentos em histórias em quadrinhos [...] (CAPELLARI, 2010, p. 231).

Plaza (1990) analisa características da arte interativa, que podem servir para a reflexão sobre as histórias em quadrinhos digitais. A internet possibilita que o artista planeje sua obra para que tenha recursos de hipermídia e confere ao leitor o poder de navegar pela história da forma como desejar. Para alguns autores, isso representa a dissolução do conceito de autoria, no entanto, é preciso ponderar o quanto a interferência do leitor o caracteriza como uma espécie de coautor da obra:

Alterar textos, diagramá-los ou os rediagramar, realizar operações de corte e
montagem, executar scripts etc., não faz de ninguém um autor, no sentido
genuíno da expressão. A chamada "dissolução do autor" só vai se consumar
fora da esfera estética, ou seja, nos grandes sistemas hipertextuais, extra-
estéticos, que atuam na chamada "função referencial" da linguagem e que
produzem montanhas de mensagens semânticas (PLAZA, 1990, p. 25-26).

Apesar das inúmeras possibilidades de inovação oferecidas pelos recursos digitais e online, Capellari (2010, p. 39) pondera que, devido aos custos e à complexidade de se produzir um material com recursos interativos e multimídia (o que pode exigir uma equipe multidisciplinar), "as formas mais comuns de quadrinhos na internet são aquelas que simplesmente utilizam o suporte digital para reproduzir páginas ou tiras que funcionariam da mesma forma no impresso".

Essa transposição do analógico para o digital é muito utilizada por autores independentes, porque possibilita a redução de custos de publicação (que, inclusive, pode ser feia de forma gratuita) e facilita o processo de divulgação. A questão é: esse tipo de produção deve ser considerado entre as definições propostas para os quadrinhos publicados na internet? As restrições impostas pela tela do computador não implicariam em mudanças no planejamento de uma HQ? Ou, ainda, as restrições impostas pelos layouts pré-definidos de blogs e websites não alterariam a forma como o quadrinista trabalha? Indo mais além: a narrativa planejada pelo autor, podendo ser alterada pelo leitor por meio de recursos interativos, ainda preserva as características tradicionalmente atribuídas às HQs?

Capellari (2010, p. 39) observa que "as histórias estão se adaptando ao ciberuniverso, novos formatos híbridos surgem e são chamados de quadrinhos por falta de um termo mais apropriado”. Em termos de modo de produção de HQs publicadas online, muitas dúvidas 
ainda surgem na hora de propor uma definição que possa abranger os novos formatos que vêm surgindo nas redes. Se antes da era digital o artista tinha que considerar fatores como as proporções de um produto impresso, a quantidade de cores que poderiam ser aplicadas e as exigências editoriais para produzir suas histórias em quadrinhos, com a internet, ele passa a se preocupar com os modos de publicação nas plataformas online, o que implica em limitações, mas, também, em um potencial de experimentação estética e narrativa.

Cabe reforçar que a discussão não envolve as HQs que são simplesmente traspostas do modo analógico para o digital, mas sim, aquelas que são pensadas desde o início para serem publicadas e lidas online. Talvez nisso consista a característica primordial para que uma publicação seja identificada como webcomic, HQtrônica ou outro termo que tenha o mesmo propósito.

Dentre as histórias pensadas para o universo online, estão as HQs que possuem recursos de interatividade, que desafiam a repensar sobre a definição tradicional de quadrinhos como uma narrativa sequencial linear, pré-definida pelo roteirista. Com a interatividade, as narrativas se desenvolvem com o auxílio do leitor, que pode atuar apenas auxiliando nas mudanças dos quadros ou definindo rumos particulares à história, que levem a um final ou outro (CAPELLARI, 2010).

A interatividade funciona como uma "relação recíproca entre usuários e interfaces computacionais inteligentes, suscitada pelo artista, permite uma comunicação criadora fundada nos princípios da sinergia, colaboração construtiva, crítica e inovadora". Diante dessa relação que não é mais unilateral, em que o leitor de quadrinhos não pode ser passivo, surgem “problemas e novas realidades de ordem perceptiva nas relações virtual/atual” (PLAZA, 1990, p. 17).

A partir do exposto, é possível observar que os autores concordam que as HQs inseridas no espaço digital não deixam de carregar as características que lhes conferem a denominação de HQs. Se levarmos em conta a definição de Ramos (2009) sobre os atributos que as caracterizam em essência, devemos considerar que HQs precisam ter narrativa sequencial e utilizar recursos gráficos próprios dos quadrinhos. No entanto, se considerarmos HQs com recursos digitais de diagramação, que alterem a sequência da leitura (ou "a "narrativa sequencial”), por exemplo, ainda é possível denominá-las dessa forma? Ou, ainda, estórias que tragam recursos de narração (áudio) em vez de das falas inseridas em balões, que são recursos verbo-visuais característicos dos quadrinhos, continuam a serem consideradas como exemplos típicos de HQs? 
O pesquisador McCloud (2006), referência no estudo sobre a linguagem dos quadrinhos, defende que nem toda HQ com recursos digitais ainda pode ser considerada uma HQ, pois as histórias precisam preservar "a natureza silenciosa e estática dos quadrinhos enquanto exploram outras capacidades da mídia digital" (McCLOUD, 2006, p. 213). Isso excluiria, por exemplo, os recursos de animação, trilha sonora, efeitos de som e diagramação dinâmica examinados por Franco (2002).

Outro ponto a ser levantado é se uma HQ, a partir do momento em que é concebida para ser publicada na internet, já recebe alterações em seu modo de produção, ou seja, mesmo sendo feita artesanalmente e depois digitalizada, é afetada pelo suporte em que se planeja publicar (a tela de um computador, tablet ou smartphone, no caso). Como Sá e Vergueiro (2015) mencionam, os autores que publicam na internet se preocupam previamente com as dimensões da tela e com a área útil dentro de uma página de navegador.

Os quadrinhos ainda encontram certa resistência ao serem incorporados em unidades de informação, embora muitos preconceitos tenham sido superados. Os estudos acadêmicos sobre histórias em quadrinhos no Brasil, cujos pioneiros foram pesquisadores como Waldomiro Vergueiro, Moacy Cirne, Álvaro de Moya e Antonio Luiz Cagnin, têm sido desenvolvidos com regularidade desde a década de 1960, o que contribui para o reconhecimento desse tipo de linguagem.

No início dos estudos sobre quadrinhos era comum associá-los a outros tipos de arte consideradas canônicas, como literatura, cinema e artes plásticas, na tentativa de que as HQs adquirissem legitimidade. Estudos de diversas áreas do conhecimento, sobretudo, da semiótica, provaram que as combinações de recursos verbo-visuais dos quadrinhos formam narrativas únicas, não cabendo compará-los com outros modos de se fazer arte.

Em relação à inserção dos quadrinhos as unidades de informação, Vergueiro (2005) observa que muitos profissionais, por não terem conhecimento sobre esse tipo de material, não sabem como classificar e disponibilizar ao público. Para suprir essa demanda, o autor oferece estudos valiosos para a área de Biblioteconomia e Ciência da Informação que servem como referência para os profissionais.

Certamente, ainda existe um grande caminho a ser percorrido até que os quadrinhos representem um material comum nas unidades de informação. No entanto, da mesma forma como vários dos preconceitos contra eles - que antes pareciam inabaláveis -, foram derrubados, é de se esperar que cada vez mais os quadrinhos possam adentrar as portas das bibliotecas e centros de documentação especializados com muito mais facilidade do que antes, sendo recebidos por profissionais preparados e dispostos a tratá-los, divulgá-los e, acima de tudo, com seu trabalho, agregar-lhes valor por meio de seu trabalho 
especializado. Até agora, a experiência tem demonstrado que isto é possível (VERGUEIRO, 2005, p. 10).

Oliveira (2014) menciona algumas iniciativas de incorporação e disseminação da produção de quadrinhos em acervos de bibliotecas, como é o caso da campanha de leitura lançada pela American Library Association, nos Estados Unidos, utilizando exemplos de super-heróis e obras em formato de graphic novels (que são edições fechadas cujo tratamento de arte e roteiro são mais elaborados e, em geral, são impressos em diversos formatos e com papel de melhor qualidade). No Brasil, vale destacar a iniciativa das "gibitecas", que são acervos especializados em HQs, presentes em várias cidades do país. Para Nogueira (2007), as gibitecas e outros acervos que incorporam histórias em quadrinhos possuem função educativa, proporcionando integração escolar:

A leitura de gibis é uma atividade prazerosa e que aparentemente está dissociada das tarefas escolares. As HQ's são capazes de promover a interdisciplinaridade entre os diversos conteúdos curriculares, ajudam a promover a prática da leitura e aproximam as crianças de outros tipos de arte, como as artes plásticas, o teatro e a música, além, é claro, de serem importantes no processo de alfabetização. Os alunos aprendem que "estudar" pode ser divertido e se tornam mais receptivos aos diversos conteúdos (NOGUEIRA, 2007, p. 175).

Os quadrinhos conquistaram espaço entre os estudos acadêmicos em diversas áreas do conhecimento, passaram a compor acervos de bibliotecas e gibitecas e o mercado editorial se preocupa com frequência em organizar antologias para deixar um legado às próximas gerações de leitores. Esse tipo de material pode ser considerado fonte de informação, à medida que "desperta, veicula uma cognição integral vinculada à leitura de mundo dos sujeitos" (OLIVEIRA, 2014, p. 140). Essa abordagem pode ser associada ao paradigma social adotado pela Ciência da Informação, que se volta para as dinâmicas de leitura que possuem potencial de transformação do sujeito e do contexto em que está inserido (CAPURRO, 2003).

Nos espaços institucionais, as HQs adquiriram relevância como objetos materiais que servem para compreender uma série de aspectos políticos e sociais de um contexto histórico. Mas os quadrinhos publicados na internet possuem a mesma validade? Podem ser considerados fontes de informação?

Para Oliveira (2014, p. 143) "situar as narrativas quadrinísticas como registro das formas de ver de pensar do mundo contemporâneo, traz para Ciência da Informação novas formas de se entender a informação e mediar os fluxos para se produzir conhecimento". Estudos indicam que as histórias em quadrinhos (sobretudo, impressas), inseridas nos espaços institucionais, são fontes de informação, servindo como documentos que motivam a circulação de conhecimento. Inclusive, são objetos utilizados nas práticas escolares, por 
possuírem uma linguagem acessível e lúdica para alunos em fase de alfabetização (NOGUEIRA, 2007).

Com a popularização da internet, os quadrinhos também migraram para sites, blogs e redes sociais. Se questionamos o caráter de fonte de informação das HQs nesse contexto, também é preciso questionar o que como essa informação é legitimada e que tipo de documentação pode ser aplicado nas mídias digitais. Do ponto de vista dos paradigmas clássicos que permeiam a Ciência da Informação, talvez seja preciso estabelecer novos critérios para um processo de "redocumentação", como observa Lund (2009).

Embora não exista uma solução rápida para o problema da documentação na web, compreender o desenvolvimento das mediações pode auxiliar a compreender de que modo a informação adquire estabilidade e legitimidade, considerando que a tecnologia digital demanda enxergar novas tipos de materialidade, que não estejam diretamente relacionadas à fisicalidade dos documentos.

\subsection{Mediações, convergência e novas possibilidades de discurso}

A desmaterialização - ou as novas formas de materialidade, como sugere Frohmann (2008) - afetam também os usos da informação. O conceito de mediações pode ser um caminho para compreender os possíveis processos de documentação na web e como a informação adquire estabilidade e legitimidade.

É evidente que as interações mediadas não surgiram com o advento das tecnologias digitais, mas, trocas culturais e simbólicas têm sido cada vez mais influenciadas pela tecnologia digital, que permite conectar pessoas em nível global.

O termo "mediação" é utilizado em diversas áreas do conhecimento e se aplica de maneira contextualizada, já que pode englobar realidades totalmente distintas. Davallon (2003) busca encontrar a definição e mediação que se aplica as áreas de Ciência da Informação e Comunicação, tratando, especificamente, da mediação cultural.

No senso comum, mediação é entendida como "ação de servir de intermediário ou de ser o que serve de intermediário" (DAVALLON, 2003, p. 6), com o objetivo de se obter uma relação que possa produzir um consenso ou um estado desejável. No uso científico, o termo adquire uma abordagem mais ampla, sobretudo, quando está ligado à mediação cultural que, de acordo com Davallon (2003), envolve questões estéticas, artísticas, culturais e dos saberes compartilhados.

$\mathrm{O}$ autor indica um terceiro uso do termo mediação, que estaria ligado aos dispositivos tecnológicos. Nessa perspectiva, duas operações se desenvolvem: a análise dos processos e 
efeitos da "tecnicização do processo de comunicação (mediação técnica) e, ao mesmo tempo, da intervenção da dimensão subjectiva nas práticas de comunicação (mediação social)" (DAVALLON, 2003, p. 9).

Considerando o uso científico do termo mediação é possível observar a necessidade de pensá-lo além de um processo de interação, mas também, de transformação da realidade.

Por conseguinte, o primeiro constato que podemos fazer é que a noção de mediação aparece cada vez que há necessidade de descrever uma acção implicando uma transformação da situação ou do dispositivo comunicacional, e não uma simples interacção entre elementos já constituídos - e ainda menos uma circulação de um elemento de um pólo para outro (DAVALLON, 2003, p. 10).

Considerando os processos comunicacionais e informacionais presentes nas redes, Marteleto (2010, p. 38) cria o conceito de "zonas de mediações", que se situa em três dimensões: 1) a "dimensão propriamente social e comunicacional", marcada pelas interações voltadas para interesses comuns; 2) a "dimensão linguística e discursiva", na qual diferentes recursos de informação são mobilizados para se atingir um objetivo e 3) a "dimensão de produção de sentidos", que ocorre quando o conteúdo das redes é capaz de "clarear" os caminhos para soluções individuais e coletivas.

As relações sociais são permeadas pela cultura, o que torna os objetos e representações produzidos por ela elementos centrais na construção do que Perroti e Pieruccini (2007) chamam de "protagonismo cultural", que seria o objetivo final das mediações.

É possível observar que as quadrinistas e leitoras brasileiras vêm se articulando nas redes sociais em torno de interesses comuns, discutindo sobre a área profissional, organizando ações coletivas para participação em eventos e feiras e divulgando trabalhos. Tais articulações podem ativar o protagonismo cultural que lhes foi negado ao longo da história, por conta de um mercado editorial pouco permeável à atuação feminina.

A pesquisa propõe analisar as representações da mulher nos quadrinhos produzidos por artistas brasileiras e publicados online. Interessa compreender as representações do feminino, considerando que o marcador de gênero e sexualidade está presente na constituição do indivíduo enquanto sujeito. Para Butler (1990, p. 25), gênero é um dispositivo discursivo e performativo, ou seja, constitui a identidade à medida que é expresso e coagido pelas "práticas reguladoras de coerência entre os sexos".

A criação não é feita de modo independente do contexto social e cultural em que é produzida e, quando as representações coletivas estão em jogo, há uma expectativa quanto à sua compreensão e apropriação por parte do leitor, o que não é um processo totalmente 
controlado por conta de diferenças "socialmente determinadas de maneiras desiguais segundo costumes, classes, inquietações" (CARVALHO, 2005, p. 157).

De modo mais amplo, documentar e investigar a produção de mulheres nos quadrinhos, enquanto representações do feminino e experiências de publicação online, pode ajudar a compreender os caminhos para garantia de espaço e visibilidade da mulher na contemporaneidade.

Com a diversificação do mercado de quadrinhos surgiram novos tipos de suporte, que relativizaram as limitações que permeavam a produção ligada aos veículos de comunicação impressa. É possível mencionar o caso dos fanzines, das graphic novels e das HQs publicadas da internet, em que a tecnologia aumenta as possibilidades de publicação e disseminação de conteúdo.

Jenkins (2008, p. 27) traz o conceito de "convergência" dos meios de comunicação, que vem mudando profundamente os modos de socialização, promovendo o que chama de "cultura participativa e inteligência coletiva". Se o mercado editorial tradicional oferece poucos espaços para atuação da mulher, a internet, como uma ferramenta acessível e de baixo custo, permite que elas publiquem e divulguem seus trabalhos de forma independente. Marteleto (2010) traz contribuições acerca da formação das redes sociais virtuais e Ugarte (2008) analisa o papel do ciberativismo contemporâneo, com base em reflexões sobre o processo de comunicação distribuída.

Nesse processo de diversificação das experiências em rede, uma questão veio à tona, movendo o circuito de produção de quadrinhos no Brasil: a falta da atuação feminina, seja no plano do consumo quanto no plano da criação. Mas será que elas, de fato, não leem e não fazem quadrinhos? Em resposta a esse questionamento, mulheres se organizam nas redes para discutir a representatividade da produção feminina e divulgar trabalhos que, muitas vezes, não chegam ao circuito mainstream de quadrinhos.

No Brasil, é possível citar grupos de discussão que se mesclam uma espécie de curadoria do que vem sendo produzido, como é o caso do Mulheres nos Quadrinhos (página do Facebook com mais de 100 mil curtidas), Mulheres em Quadrinhos (grupo no Facebook com mais de 3 mil membros), Lady’s Comics (site e página no Facebook com mais de 20 mil curtidas) e o Zine $X X X$ (grupo exclusivo para mulheres e transexuais com mais de 3 mil membros).

Criado em 2010, o site Lady's Comics (ladyscomics.com.br) traz o slogan "HQ não é só para o seu namorado". O site "fala de mulheres que estão presentes (ou que já se foram) no universo dos quadrinhos", de acordo com o texto de apresentação da página do Facebook. A 
página inserida nessa mesma rede social possui mais de 19 mil curtidas e, em 2014, foi realizado o $1^{\circ}$ Encontro Lady's Comics, em Belo Horizonte, financiado por crowdfunding (viabilizado pela plataforma Catarse). Em 2016, será realizado o $2^{\circ}$ Encontro, que irá reunir cerca de 30 convidadas para discutir os rumos da produção feminina.

A iniciativa do Zine $X X X$ surgiu no início de 2014, a partir da manutenção de um grupo de discussão sobre mulheres nos quadrinhos na rede social Facebook. O grupo aceita a participação exclusiva de mulheres e transexuais e funciona como um espaço de socialização da produção feminina, discussões sobre gênero, organização de atividades e eventos ligados aos quadrinhos. O Zine $X X X$ é referência de um espaço acolhedor para artistas que estão começando e que se deparam com um cenário ocupado historicamente por homens e pouco permeável à atuação feminina. A idealizadora do projeto é Beatriz Lopes, que se dedicou a reunir 70 mulheres para produção de 5 zines, além do grupo de discussão, que possui mais de 3 mil membros.

Do reconhecimento da falta de visibilidade da produção de mulheres no Brasil e da falta de um espaço de discussão sobre as representações femininas inseridas dentro e fora das histórias em quadrinhos, surgiu a necessidade de criação de plataformas em que tudo isso pudesse ser contemplado.

Em 2015, a 27 edição do Troféu HQMIX, que é a maior premiação de quadrinhos existente no Brasil, contou com, aproximadamente, $82 \%$ de pré-indicações masculinas (121 obras feitas exclusivamente por homens) e 13\% de pré-indicações femininas (19 obras feitas exclusivamente por mulheres) - o restante são obras feitas a partir de parcerias entre homens e mulheres ou coletâneas nas quais não foi possível identificar todos os autores envolvidos. Isso mostra que o campo dos quadrinhos, assim como muitos outros campos profissionais e artísticos, ainda é um espaço no qual predomina o reconhecimento do trabalho masculino.

No Festival Internacional de La Bande Desinné d'Angoulême, o maior evento de premiação de quadrinhos da Europa, nenhuma mulher foi indicada em 2016, algo que foi noticiado em várias partes do mundo e mobilizou mulheres quadrinistas, sobretudo, nas redes sociais. Isso mostra que o campo dos quadrinhos, assim como muitos outros campos profissionais e artísticos, ainda é um espaço no qual predomina o reconhecimento do trabalho masculino.

As mulheres passam a contestar a falta de visibilidade e representação no meio dos quadrinhos, reivindicando um espaço "próprio", utilizando os recursos da internet como ferramenta de divulgação e discussão. A cultura da convergência envolve as mudanças trazidas pela tecnologia digital, tanto no plano das grandes corporações de entretenimento 
quanto no uso das mídias pelos consumidores, que acabam assumindo papeis dentro na produção cultural. Jenkins $(2008$, p. 46) sintetiza que "a convergência, como podemos ver, é tanto um processo corporativo, de cima para baixo, quanto um processo de consumidor, de baixo para cima" e o que está em jogo nesse processo não envolve apenas assuntos ligados ao entretenimento, mas sim, um fluxo amplo de ideias.

Consumidores estão aprendendo a utilizar as diferentes tecnologias para ter um controle mais completo sobre o fluxo da mídia e para interagir com outros consumidores. As promessas desse novo ambiente de mídia provocam expectativas de um fluxo mais livre de ideias e conteúdos. (JENKINS, 2008, p. 46).

Com a internet e as redes sociais, é comum que as pessoas busquem interagir de acordo com interesses pessoais que dialogam com os interesses de outros usuários, o que possibilita a formação de uma espécie de "inteligência coletiva", em que os "membros trabalham juntos para forjar novos conhecimentos, muitas vezes em domínio em que não há especialistas" (JENKINS, 2008, p. 48) em relações marcadas pela diversidade de opiniões e pela solidariedade.

É possível observar algo muito próximo à ideia de inteligência coletiva se desenvolvendo em grupos nas redes sociais que discutem as condições da produção feminina de quadrinhos no Brasil. Eles surgiram para questionar a falta de representatividade de mulheres no mercado editorial e para refutar o senso comum de que mulheres não leem quadrinhos, que não formam um público consumidor suficientemente grande que possa ser levado em consideração. Esses grupos, que surgiram com um caráter de resistência ao modo mainstream de produção de HQs (como, por exemplo, publicações em grandes jornais e editoras), levantam discussões que se espalham rapidamente pelas redes e mobilizam centenas de usuários.

Iniciativas que questionam a produção cultural verticalizada, característica da cultura de massa, fazem parte do cenário da convergência nas mídias digitais e representam uma revitalização dos processos comunicacionais tradicionais. Compreender o funcionamento da cultura participativa nas redes é fundamental para compreender as formas contemporâneas de consumo midiático (JENKINS, 2008).

É interessante notar as novas relações que as pessoas estabelecem com a cultura, reivindicando a pouca permeabilidade de atuação no modelo da comunicação de massa, em que grandes corporações nacionais e globais dominavam (e dominam) a produção. 
Jenkins (2008, p. 43) pontua que "o público, que ganhou poder com as novas tecnologias e vem ocupando um espaço na intersecção entre os velhos e os novos meios de comunicação, está exigindo o direito de participar intimamente da cultura”.

Hall (1997) sinalizou o papel fundamental da cultura em todos os níveis da vida social, sobretudo, após a era industrial. Mudanças na vida local e cotidiana, envolvendo trabalho, lazer, religião e família marcam a intensificação de conflitos geográficos, étnicos e de gênero, que vão além da questão de classe. Nesse contexto, as minorias passam a sentir que são vítimas e não participantes ativas da mudança cultural, questionando para quê e por quem ela é pensada.

A internet e as redes sociais parecem oferecer espaço para que esses questionamentos e conflitos sejam debatidos, ainda que exista uma infinidade de mecanismos de vigilância e controle que limita a circulação livre de ideias. A formação de grupos interessados em discutir a produção feminina de quadrinhos, bem como divulgar trabalhos feitos por mulheres, é um sinal de que há espaço para novas interpretações sobre o mundo, novas possibilidades de discurso.

\subsection{Redes sociais e blogosfera como formas de comunicação distribuída}

Iniciativas como as do Lady's Comics e Zine $X X X$ só existem por meio das ferramentas online e do desenvolvimento de uma comunicação que não perpassa pelos filtros da grande mídia, nos moldes da comunicação de massa do século XX - embora não seja segredo que as redes são controladas por empresas globais que utilizam sistemas de vigilância sofisticados para direcionar a navegação dos usuários.

Castells (2003) discute os limites e potencialidades da cultura digital, a partir de uma análise do "estado da arte" dos processos mediados pelas novas tecnologias. O autor se preocupa em não cair nos lugares comuns que colocam a internet como algo libertário e revolucionário em si. Ele ressalta que foi criada uma mitologia em torno do assunto, que acaba por reproduzir discursos alienados, embora o próprio autor tenha uma visão predominantemente positiva acerca do potencial da tecnologia digital como ferramenta de transformação social.

Os usos que as pessoas fazem da tecnologia é que determinam seu potencial de transformação, mas é válido destacar que a internet, de acordo com Castells (2003) foi idealizada como um instrumento de comunicação livre.

(...) famosa idéia de que a Internet é algo de incontrolável, libertário, etc. está na tecnologia, mas porque ela foi desenhada, no curso da sua história, 
com esta intenção. Quer dizer, é um instrumento de comunicação livre, criado de forma múltipla por pessoas, setores e inovadores que queriam que fosse um instrumento de comunicação livre. Nesse sentido, creio que há que ter em mente que as tecnologias são produzidas por seu processo histórico de constituição e não simplesmente por desenhos originais da tecnologia. (CASTELLS, 2003, p. 262).

A internet tem sido apropriada por organizações de movimentos sociais e de mobilizações esporádicas com considerável frequência nos últimos anos, tanto para coordenar ações que ocorrerão no espaço público offline, quanto para desenvolver discussões, a partir dos grupos que se formam em torno de pautas de interesse comum. Um exemplo disso foi a campanha promovida pelo Collectif des créatrices de bande dessinée contre le sexisme (Coletivo de Autoras de Quadrinhos Contra o Sexismo), em 2016, contra a falta de mulheres indicadas ao prêmio de Angoulême, que é a maior premiação de quadrinhos da Europa. Entre os trinta nomes indicados à categoria Grand Prix, que, historicamente, homenageia nomes proeminentes do cenário de quadrinhos, não constava nenhuma autora. O coletivo de quadrinistas lançou uma campanha online, através do uso da hashtag "\#WomendoBD" (mulheres fazem quadrinhos), propondo que artistas boicotassem o evento (ATHAYDE, 2016).

Figura 17 - Cartum de Aimee de Jongh feito para protestar contra os resultados do Festival de Angoulême

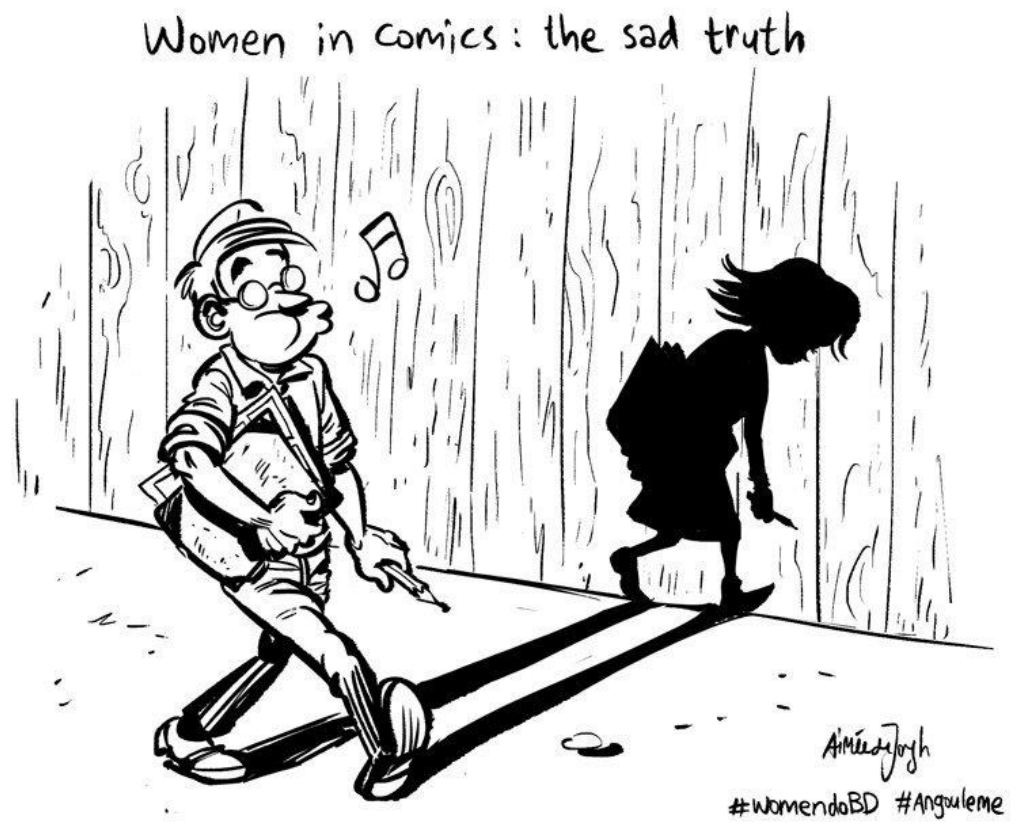

Fonte: http://minasnerds.com.br/2016/01/07/mulheres-que-fazem-quadrinhos-e-o-boicote-a-angouleme/

Também é possível destacar a migração das mobilizações online para as ruas, mencionando manifestações como a "Marcha do parto em casa", a "Marcha contra a mídia 
machista" e a "Marcha das Vadias", que reuniram mulheres em diversas localidades do país para protestarem contra a desigualdade de gênero e pelo fim da violência contra a mulher que, por vezes, é legitimada pelos discursos patriarcalistas que se materializam nas instituições de poder (LIMA, 2013).

O conceito de redes sociais é compreendido por Marteleto (2010) como algo cada vez mais presente no discurso de organizações, na mídia, na academia e no senso comum. É preciso fazer a ressalva de que ele antecede aos meios virtuais, compreendendo a sociedade "a partir dos vínculos relacionais entre os indivíduos, os quais reforçariam suas capacidades de atuação, compartilhamento, aprendizagem, captação de recursos e mobilização" (MARTELETO, 2010, p. 28). No contexto de difusão da internet, as redes sociais operam em dois sentidos:

Primeiro, configurar o espaço comunicacional tal qual representado e / ou experienciado no mundo globalizado e interconectado no qual se produzem formas diferenciadas de ações coletivas, de expressão de identidades, conhecimentos, informações e culturas. Segundo, indicar mudanças e permanências nos modos de comunicação e transferência de informações, nas formas de sociabilidade, aprendizagem, autorias, escritas e acesso aos patrimônios culturais e de saberes das sociedades mundializadas (MARTELETO, 2010, p. 28).

O uso das tecnologias de informação e comunicação (TICs) envolvem, no mínimo, três níveis de redes: "a rede tecnológica (mecanismos e ferramentas de informática); a rede semântica (relações, elos, estratégias, etc.); a rede humana (interações entre pessoas) as quais influenciam os procedimentos intelectuais e as relações sociais" (MARTELETO, 2010, p. 33). É possível encontrar os três níveis no grupo Zine $X X X$, uma vez que os recursos tecnológicos são utilizados com o propósito de promover a produção feminina de quadrinhos, a partir de estratégias de comunicação (que podem ser bem definidas, como no caso de publicações via financiamento coletivo) e por meio de debates acerca dessa produção.

A criação de espaços em que os usuários são, ao mesmo tempo, consumidores e produtores de informação não surgiu com as redes sociais da forma como conhecemos hoje por meio de ferramentas como Facebook, Twitter, Instagram, etc. O espaço informativo que se desenvolveu a partir da popularização do uso de blogs (chamado por alguns autores de "blogosfera") permitiu a formação de um meio de "comunicação distribuída", utilizando o termo de Ugarte (2008). De acordo com o autor, “os blogs são sistemas pessoais, automáticos e simples de publicação", que reproduzem os "pressupostos, as condições e os resultados do mundo pluriárquico", permeável a diversos tipos de discurso, antes excluídos ou ocultados nas mídias de comunicação de massa (UGARTE, 2008, p. 27). É possível traçar um paralelo 
entre os usos da blogosfera e das redes sociais, considerando que ambos estão incluídos em uma estrutura de comunicação distribuída:

Na prática, a emergência de uma esfera informativa pluriárquica, que é o que de forma primitiva representam a blogosfera, os agregadores identitários e os novos pressclippings pessoais, supõe um verdadeiro processo de reorganização do poder que tende a uma estrutura de informação distribuída (UGARTE, 2008, p. 30).

As redes se tornaram também um espaço de disputa, em que a multiplicidade de discursos pode ser publicamente confrontada. A blogosfera feminista, por exemplo, é destinada a discutir questões de gênero, em oposição aos discursos patriarcalistas, considerados hegemônicos. Desse modo, a blogosfera feminista se desenvolve como "espaço de confronto" a tais discursos, de acordo com Lima (2013, p. 01):

A popularização da internet contribuiu para fazer circular massivamente discursos de valorização do feminismo. Através de comunidades virtuais, blogs pessoais e páginas no Facebook, testemunhamos diversos tipos de intervenções on-line. Por ser um canal de comunicação em tempo real, o alcance das ações pode chegar a uma proporção global (LIMA, 2013, p. 01).

As blogueiras feministas podem ser consideradas ciberativistas, cujo papel é mediar a informação, inserida no contexto em que predomina a forma de comunicação distribuída. A popularização do computador pessoal e da internet permitiu que novos atores se manifestassem nos processos comunicacionais em uma rede, permitindo um "verdadeiro processo de reorganização do poder que tende a uma estrutura de informação distribuída" (UGARTE, 2008, p. 30) e não mais centralizada (caracterizada pelo monopólio dos grandes meios de comunicação) ou descentralizada (em que a presença da opinião pública era aceita após um processo de filtragem).

Em conjunto, a blogosfera tende a eliminar a separação emissor/receptor (é uma rede distribuída em que todos podem publicar), característica dos meios dos modelos centralizado (experimentados nos países que sofreram regimes totalitários, como a Espanha) e descentralizado (modelo midiático anglo-saxônico democrático) (UGARTE, 2008, p. 27).

O ciberativista "é alguém que utiliza Internet, e, sobretudo, a blogosfera, para difundir um discurso e colocar à disposição pública ferramentas que devolvam às pessoas o poder e a visibilidade que hoje são monopolizadas pelas instituições" (UGARTE, 2008, p. 42). A utilização de ferramentas digitais para dar visibilidade a discursos alternativos constitui o pilar do ciberativismo. 
É evidente que existem outros espaços de socialização do que é feito em termos de HQs, sem a especificidade de abordar a produção feminina (como eventos nacionais ou regionais, blogs, sites e grupos nas redes sociais), mas, essas iniciativas podem não ser capazes de refletir a quantidade e complexidade dos trabalhos que têm sido desenvolvidos por mulheres, sobretudo, com as possibilidades da internet como meio de divulgação. É possível dizer que a internet e os recursos oferecidos pelas redes sociais possibilitam a inserção de novos discursos, antes invisibilizados pelas formas de comunicação centralizadas ou descentralizadas (UGARTE, 2008). Na formação da inteligência coletiva, mencionada por Jenkins (2008), os "membros trabalham juntos para forjar novos conhecimentos, muitas vezes em domínio em que não há especialistas" (JENKINS, 2008, p. 48) em relações marcadas pela diversidade de opiniões e pela solidariedade.

As redes sociais estão presentes em muitos aspectos da vida cotidiana e envolvem expressões de identidade e formas de sociabilidade (MARTELETO, 2010). É nesse sentido que os grupos formados nas redes sociais - como é o caso do Zine $X X X$, que adquiriu projeção do cenário dos quadrinhos através do Facebook - podem ampliar as formas de expressão de identidade, a partir da divulgação de representações diversas sobre o feminino. Além disso, cria-se um espaço para que as autoras de quadrinhos possam disseminar seus trabalhos de forma independente, sem as barreiras impostas pela seleção do mercado editorial. 


\section{AS QUADRINISTAS BRASILEIRAS NA INTERNET}

Em 2016, ocorreu o $2^{\circ}$ Encontro Lady's Comics, Em Belo Horizonte (MG), que reuniu mulheres quadrinistas de diversos estados para discutirem sobre suas produções e atuação no mercado, com um público de cerca de 500 pessoas, de acordo com informações da organização do evento. O evento foi realizado entre os dias 29 e 31 de julho, em parceria com a organização do FIQ (Festival Internacional de Quadrinhos).

Nessa ocasião, aproveitamos para entrevistar algumas autoras que publicam na internet e que poderiam fazer parte da amostra da pesquisa. Oito autoras responderam um questionário com dez perguntas e contaram sobre suas trajetórias nos quadrinhos, referências e o que pensam sobre a representação das personagens femininas.

As autoras tinham idade entre 23 e 28 anos, na época de aplicação do questionário, e residem em Curitiba (PR), Belo Horizonte, Brasília (DF), Rio de Janeiro (RJ) e São Paulo (SP). A maioria possui graduação em artes plásticas ou design gráfico e duas são da área de comunicação social.

Embora a amostra inicial seja pequena, é possível observar alguns padrões entre as respostas: todas as entrevistadas, apesar de terem começado a publicar seus quadrinhos na internet, em blogs, sites ou páginas nas redes sociais, possuem publicação impressa; todas publicam online há mais de 2 anos; sete delas costumavam ler mangás e gibis nacionais na infância; todas declaram ter o hábito de ler quadrinhos feitos por mulheres e começaram a ter contato com essas produções entre 15 e 25 anos de idade e seis delas acreditam que há diferenças no modo como personagens femininas são representadas, comparando HQs feitas por homens e mulheres.

As autoras entrevistadas encontram na internet oportunidade de publicar gratuitamente, alcançar um número maior de pessoas, desenhar quadrinhos com frequência e, mais recentemente, cumprir a demanda de desenhar para plataformas de streaming, como no caso da quadrinista Cris Peter.

A amostra final foi levantada a partir dos registros de quadrinistas no site Lady's Comics, que encontram na guia BAMQ! (Banco de Mulheres Quadrinistas), em que autoras podem se cadastrar voluntariamente. Também buscamos nomes no grupo Zine $X X X$, no tópico "Apresentações", em que as mulheres descrevem o próprio trabalho.

a) Bianca Pinheiro, autora da webcomic Bear 
Bianca Pinheiro, de 29 anos, é autora da webcomic Bear e venceu o Troféu HQMIX, de 2015, na categoria "Roteirista revelação", além de ter sido indicada em diversas categorias em 2016 e 2017. Ela possui uma experiência mais ampla com o mercado editorial nacional do que as outras entrevistadas, já que trabalhou na série Turma da Mônica Laços, com a HQ intitulada Força, pela Mauricio de Sousa Produções, que produz os quadrinhos da Turma da Mônica.

A autora criou Bear, uma webcomic infanto-juvenil, publicada desde 2013, cuja história gira em torno da pequena Raven, uma criança que se perde no caminho de casa e acaba parando na caverna de um urso. O urso, chamado Dimas, apesar de rabugento, decide ajudar a menina a voltar para casa e assim começa a jornada dos dois.

Bianca conta que sua webcomic foi pensando desde o início para publicação online, porque ela queria ter o compromisso de publicar uma vez por semana em seu Tumblr, que é uma ferramenta semelhante a um blog. Ela esperava ter um feedback imediato dos leitores e comenta que publicar a história em trechos semanais era uma forma de conciliar o tempo com o trabalho fixo de 8 horas por dia em uma empresa.

Sobre a repercussão provocada pela publicação online, ela conta que, no começo, só alguns amigos liam. Com os compartilhamentos nas redes sociais, ela formou "uma pequena rede de leitores". Bianca tem trabalhos publicados na versão impressa e acredita que "ser só digital ainda parece amador", por isso, defende que o "impresso valida o quadrinho".

Além da importância de ter material impresso, ela destaca a função da mídia especializada em quadrinhos: "a minha pequena experiência no mundo dos quadrinhos me mostra que quem mais movimenta as coisas são os YouTubers de quadrinhos" (Apêndice A). Ela atribui ao fato de conseguir vender trabalhos impressos de forma independente à divulgação feito em canais como Dois Quadrinhos e Pipoca e Nanquim. Além dos canais no Youtube, críticas em sites e blogs também são importantes para promover o artista que comenta que "as críticas (positivas) em blogs e sites servem também para mostrar aos leitores que tem gente lendo nosso quadrinho e se importando com eles o suficiente para falar a respeito" (Apêndice A).

b) Brendda Costa Lima, autora da webcomic Manual de sobrevivência à vida adulta

Brendda Costa Lima, 24 anos, é autora da webcomic Manual de sobrevivência à vida adulta, publicado desde 2016, na plataforma Medium. Ela foi indicada ao HQMIX 2016 na categoria "Colorista Nacional". Ela relata as frustrações de não conseguir publicar com mais frequência: "a atualização não é tão frequente quanto eu queria. Eu fico muito ansiosa por trabalhar e não ter mais tempo pra desenhar então eu passei um bom tempo travada" 
(Apêndice A). Manual de sobrevivência à vida adulta é uma história sobre ser mulher e sentir ansiedade. É sobre "crescer, ter chefes ruins, chegar ao fim do mês sem grana é algo tão comum pra personagem quanto os gatinhos fantasmas que falam com ela".

Brendda começou a publicar a webcomic, mas ainda não sabia bem como queria continuar com a história. Quando percebeu que muitas leitoras se identificavam, decidiu continuar publicando online. "Eu acho que quadrinhos digitais tem mais reconhecimento entre o público do que os impressos", afirma Brendda. Ela comenta sobre as vantagens da internet em alcançar pessoas de vários lugares: "nosso país é gigante e eu ainda me impressiono com o fato de ter gente no RS que lê minhas coisas" (Apêndice A).

c) Cátia Ana, autora da webcomic $O$ diário de Virgínia

A quadrinista de 34 anos é autora das webcomics $O$ diário de Virgínia, que foi publicada entre 2010 e 2016. A obra já foi publicada em versão impressa, em dois volumes, pela editora Marca de Fantasia, em 2014 e 2015. A autora foi indicada duas vezes ao HQMIX, na categoria Web quadrinhos por sua webcomic.

O Diário de Virgínia é uma história com traços autobiográficos onde a personagem Virgínia "lida com seus medos e conflitos internos ao dialogar com eles transmutados em personagens", conta a autora. "A escolha do digital foi porque senti necessidade de publicar e, como meu trabalho não estava maduro, me autopublicar foi a melhor escolha", relata.

d) Cris Peter, autora da webcomic Quimera

A autora Cris Peter, de 34 anos, publica a webcomic Quimera, desde 2016. Cris é conhecida por seu trabalho como colorista e já publicou o livro teórico "O uso das cores", pela editora Marsupial, em 2014. Ela já foi premiada no Troféu HQMIX na categoria “Colorista Nacional”, em 2017 e foi indicada, em 2012, ao Eisner Awards pela colorização da HQ "Casanova”, de Matt Fraction, desenhada pelos quadrinistas Fábio Moon e Gabriel Bá. Cris desenvolve trabalhos de colorização para grandes editores norte-americanas, como Marvel e DC Comics.

A webcomic de ficção Quimera é publicada pela plataforma de streaming Social Comics, em que o leitor paga para ter acesso mensal a um acervo de conteúdo. Cris Peter é responsável pelo roteiro e cores, enquanto Dika Araújo faz os desenhos. Na história, duas mulheres, Nicole e Anna, têm as vidas interligadas após descobrirem um poder que as transforma em um ser apelidado de Quimera.

Ela conta que a HQ surgiu a partir da demanda dos organizadores da Social Comics e que sempre teve interesse em publicar a HQ impressa quando a história fosse finalizada. Embora houvesse essa vontade de trazer a história para o impresso, ela criou o roteiro 
pensando no formato da plataforma de streaming: "na hora do desenvolvimento de roteiro, tive a preocupação de deixar um 'gancho' no último quadro de cada página para dar ao leitor a curiosidade de saber o que acontece" (Apêndice A), considerando que as páginas eram publicadas individualmente em uma frequência que varia de acordo com a disponibilidade de tempo das artistas.

Cris divulga seus trabalhos nas redes sociais Facebook e Instagram, mas critica a restrição do alcance: "o nicho dos quadrinhos é muito restrito e a divulgação é muito dificultada pelas constantes mudanças de algoritmo das plataformas digitais" (Apêndice A). Ela observa que mesmo seus seguidores mais assíduos têm dificuldades de saberem das novidades de seu trabalho e que ter um material impresso implica nas mesmas dificuldades de divulgação da publicação digital, já que os quadrinhos autorais atingem um nicho muito específico de leitores.

e) Fernanda Ferreira, autora da Webcomic Como eu realmente...

Fernanda Ferreira, que assina seus trabalhos como Fernanda Nia, tem 27 anos e é autora da webcomic Como eu realmente..., publicada desde $2011 \mathrm{em}$ seu site. Fernanda nunca foi indicada a prêmio. Ela produz HQs sobre a personagem Niazinha, que imagina várias situações agindo de acordo com a própria vontade, enquanto a vida real é muito menos livre.

Fernanda pensou em publicar na internet porque era um trabalho despretensioso, no início. "Começou como uma forma de exposição do meu trabalho $100 \%$ despretensiosa. [...] Não havia planos de transformar o projeto em algo maior que um blog de tirinhas e piadinhas" (Apêndice A).

Fernanda acredita que "é mais fácil ficar famoso, digamos assim, com seu conteúdo viralizando online", porém, "os quadrinhos impressos ainda são vistos como algo mais 'importante', mais formal, tanto pelo próprio público quanto pela crítica” (referência). Ou seja, ter um material impresso garante a validação do trabalho da quadrinista e ela encontra resenhas de seus livros de quadrinhos feitas por leitores em sites de livros como o Skoob, Goodreads e blogs literários. Mas a divulgação online ainda é fundamental para atrair novos leitores, seja por amigos que compartilham nas redes sociais, até blogs e canais de Youtube que falam do trabalho.

f) Gabriela Masson, autora da webcomic Garota siririca

Gabriela Masson, que assina seus trabalhos como Lovelove6, tem 27 anos e publica a webcomic Garota Siririca, desde 2013. Ela foi indicada ao HQMIX 2016 na categoria "Publicação Erótica". A webcomic começou a ser publicada online no site da Revista Samba e 
hoje é publicada no site da autora. A história gira em torno de uma personagem viciada em masturbação, que se mete em confusões com suas amigas por conta do vício.

Gabriela decidiu publicar online e gratuitamente para alcançar mais pessoas e porque não tinha conhecimento nem dinheiro para trabalhar com publicações impressas. Por um ano e meio a quadrinista publicou uma página por semana, depois, a passou a não ter regularidade.

Para ela, a repercussão de sua webcomic vem da "indicação de pessoas que já leram a história antes" (referência). Sobre as diferenças entre publicar online e impresso, ela pontua a diferença entre autores homens e mulheres no mercado editorial e o enfoque nas publicações impressas dado em premiações: "há muito menos mulheres se publicando e sendo publicadas por editoras, em formato impresso, do que homens; e todos os prêmios brasileiros com categorias de histórias em quadrinhos privilegiam o formato impresso" (Apêndice A).

g) Germana Viana, autora da webcomic Lizzie Bordello e as Piratas do Espaço

Aos 45 anos, a paulistana é autora da webcomic Lizzie Bordello e as Piratas do Espaço, publicada em site hospedado no Blogger desde 2013, e "As empoderadas", publicada na plataforma Social Comics, desde 2017. A quadrinista possui uma carreira extensa no mercado editorial de HQs e, trabalha como agenciadora de artistas para editoras estrangeiras pela Jambô Editora, além de ser letrista da Panine, Jambô e Riot. Em 2017, recebeu o Troféu HQMIX na categoria Web quadrinhos pela criação de "As empoderadas" e já havia sido indicada nas duas edições anteriores do prêmio.

Lizzie Bordello e as Piratas do Espaço é uma HQ de ficção científica, "bagaceira, baixo orçamento, com muito humor nonsense. São quatro piratas que viajam pelo espaço se envolvendo em aventuras um pouco confusas", de acordo com a autora. As Empoderadas é uma história sobre garotas que ganham superpoderes depois de um acidente climático. Não foi possível analisar a HQ “As empoderadas", pois ela foi tirada do ar para negociação contratual e sem previsão de retorno, de acordo com a Germana Viana.

A autora possui três volumes impressos de Lizzie Bordello e conta que nunca se preocupou se a HQ seria só online ou também impressa, pois cada escolha traz resultados diferentes e em termos de custo e alcance. "Eu penso nas duas vertentes porque é muito legal ver um material impresso e online. Quanto mais opção melhor", diz ela.

h) Lita Hayata, autora da webcomic Bete vive

Lita Hayata, 31 anos, publica sua webcomic "Bete Vive" há quatro anos. Ela foi préindicada ao HQMIX 2015, na categoria "Novo Talento Desenhista". A história da webcomic Bebe Vive é sobre uma mulher adulta que tenta se virar aos trancos e barrancos e recebe a visita da personagem Morte, que passa a morar com ela. 
Ela conta que a HQ foi pensada para o online, depois de ela começar a enviar trabalhos para uma publicação coletiva independente chamada Trucko. A partir dessa demanda, ela procurou uma ferramenta para publicar, optando pelo Tumblr. A autora tenta publicar duas vezes ao mês, mas confessa que há grandes hiatos na produção.

Sobre a repercussão dos quadrinhos online, ela acredita que a internet garante mais visibilidade, mas não maior reconhecimento no meio dos quadrinhos. Quem acessa sua webcomic, geralmente, são amigos ou seguidores curiosos, que chegam aos seus trabalhos depois que ela "alardeia" nas redes sociais.

Ao questionarmos a sobre a lacuna de representatividade das quadrinistas precisamos refletir sobre o que tornaria essa representatividade possível. Questionadas sobre isso, as autoras entrevistadas apontaram dois caminhos: o editorial e o numérico.

As escolhas editoriais envolvem não só contratar artistas para publicações em editoras, mas, também, participarem de coletâneas, curadoria de eventos e premiações. "Atualmente acho que principalmente nós reivindicamos curadorias editoriais preocupadas em compensar o machismo histórico do mercado e em valorizar e incentivar os trabalhos de jovens autoras", afirma Gabriela Masson. Outra questão é a presença majoritariamente masculina entre os editores e, como acrescenta Fernanda Nia, entre os críticos de quadrinhos: "a grande maioria da crítica é masculina. A editoração é feita por homens e com um olhar masculino. [...] Se o quadrinho é fofo, ou trata de cotidiano feminino, por exemplo, eu vejo uma tendência a considerá-lo como inferior".

Bianca Pinheiro aponta outro caminho para a questão editorial, que é o da adequação de uma HQ a temáticas que rendam alguma repercussão: "Posso estar muito enganada, mas acredito que o reconhecimento de um trabalho ocorre quando ele consegue se encaixar em alguma categoria de coisas que fazem algum sucesso no momento". Nessa perspectiva, a influência de escolhas editoriais baseadas em gênero, não se aplica, embora a autora reconheça que ainda existe um número muito maior de homens produzindo quadrinhos do que mulheres.

O outro caminho apontado para explicar as diferenças de atuação entre os gêneros é o numérico, no sentido de que "o número de publicações produzidas por homens é maior", como acredita Lita Hayata. Sobre essa discussão, é preciso considerar que existem diferenças no modo de produção de HQs de super-heróis, que consiste em um dos polos, e do outro, os quadrinhos autorais. O mercado de quadrinhos de heróis é historicamente marcado pelas editorias masculinas e voltado para o público masculino. Trina Robbins tem um trabalho de recuperação das informações sobre artistas e roteiristas que atuaram no mercado norte- 
americano e que sofreram uma espécie de apagamento histórico (ROBBINS, 1993). Nesse sentido, é possível pensar na naturalização da presença masculina dentro das editoras e da produção de HQs de heróis.

Por outro lado, no campo dos quadrinhos autorais, que não possui critérios fixos de produção, é possível pensar em uma maior atuação feminina, embora seja difícil encontrar dados precisos. "Se o reconhecimento for em um mercado como o de super-heróis americanos, imagino que o caminho seja desenhar, escrever e colorir como se espera no mercado. Em matéria de quadrinho autoral, é difícil saber”, observa Bianca Pinheiro.

A desigualdade numérica (no sentido de que historicamente um número maior de homens fazem quadrinhos em comparação com as mulheres) é tratada pelas entrevistadas como algo que perpetua a desigualdade de atuação no mercado ou como consequência direta do machismo estrutural, que inibe a presença feminina de produzirem e de projetarem uma carreira profissional.

A divulgação na imprensa, sobretudo por meio de sites especializados em quadrinhos ou que agreguem um nicho de público relacionado ao que as autoras produzem é considerada importante, de forma unânime. O principal ponto levantado é a importância da indicação da imprensa como forma de legitimação, não apenas como divulgação de um trabalho. "É importante para me legitimar como autora, fazer o registro do meu trabalho e compartilhar com o público as minhas reflexões sobre os quadrinhos que ele tem lido", destaca Gabriela Masson. Outro aspecto é o incentivo para que outras mulheres produzam quadrinhos, como enfatiza Cris Peter: "Quanto mais mulheres e meninas tiverem conhecimento da minha existência no mercado, mais elas verão a possibilidade de também seguirem esse caminho artístico".

Para que as produções femininas tenham mais espaço na imprensa e mídia especializada, é preciso superar barreiras que, novamente, esbarram nos padrões estabelecidos por um mercado dominado pelo masculino, nos quadrinhos e na comunicação. Fernanda Nia aponta os caminhos para que isso aconteça: "falta trabalharmos o preconceito de que o material feminino ou e temática feminina é inferior e falta, e [...] mais espaço para mulheres no topo da cadeia produtiva e de comunicação de quadrinhos, não só na produção". "Acho que deveria vir do público leitor, uma história deveria ser lida independente do gênero do autor, mas a gente acaba percebendo que por ser mulher já há uma resistência antes mesmo da pessoa ver o que você produziu", explica Cátia Ana.

Identificados os motivos que levam à falta de representatividade e de visibilidade, cabe falar das estratégias das entrevistadas para ampliar a participação feminina. 
Planejamento, organização, regularidade na produção e aprimoramento técnico são características apontadas como fundamentais para o trabalho com quadrinhos. Algumas entrevistadas apontam que, enquanto não houver equidade, é preciso conquistar mais "visibilidade e inclusão nos círculos de negociação" nas editoras, nos meios de comunicação e nas curadorias. Outra recomendação destacada pelas autoras é a formação de parcerias com outras pessoas que trabalham com quadrinhos, sobretudo outras mulheres: "Falta a gente superar as imensas distâncias geográficas entre nós e bolarmos projetos e oportunidades pra nós mesmas", defende Gabriela Masson.

A internet passou a ser um espaço de negociação, em que os padrões do mercado editorial de quadrinhos são relativizados e leitores e leitoras podem ter acesso a uma infinidade de produções, incluindo as de mulheres, experientes ou iniciantes, que escolhem os quadrinhos como forma de expressão. Não se trata de lutar por um espaço no mercado já estabelecido, mas criar novos espaços possíveis para a socialização da produção feminina e formar leitores com um conteúdo mais diverso. 


\section{ANÁLISE TEMÁTICA}

As oito autoras selecionadas tinham idade entre 24 e 45 anos (na época de coleta da amostra) e são de cinco estados diferentes. Todo o protagonismo é de personagens femininas. Quatros delas são disponibilizadas em plataforma de streaming paga, o Social Comics, sendo que três também podem ser visualizadas em sites gratuitos.

Em uma análise dos cada webcomic podemos agrupar certas características. Três entre as oito possuem traço autobiográficos e apenas Brendda Costa Lima, autora de Manual de sobrevivência da vida adulta, declara se retratar como personagem. As HQs com traços autobiográficos, noção utilizada para designar quadrinhos cujas temáticas se aproximam com a história das próprias autoras, são: Como eu realmente, Bete Vive, Diário de Virgínia. As quatro HQs restantes se encaixam na categoria de ficção e todas trazem elementos fantásticos e personagens não-humanos. São elas: Garota Siririca, Bear, Lizzie Bordello e as Piratas do Espaço, Quimera e “As empoderadas”.

Antes de apresentarmos a análise temática, sintetizamos brevemente o conteúdo de cada webcomic:

Bear (de Bianca Pinheiro): webcomic infanto-juvenil publicada desde 2013, cuja história gira em torno da pequena Raven, uma criança que se perde no caminho de casa e acaba parando na caverna de um urso. O urso, chamado Dimas, apesar de rabugento, decide ajudar a menina a voltar para casa e assim começa a jornada dos dois.

Figura 18 - Fragmento da HQ Bear, de Bianca Pinheiro

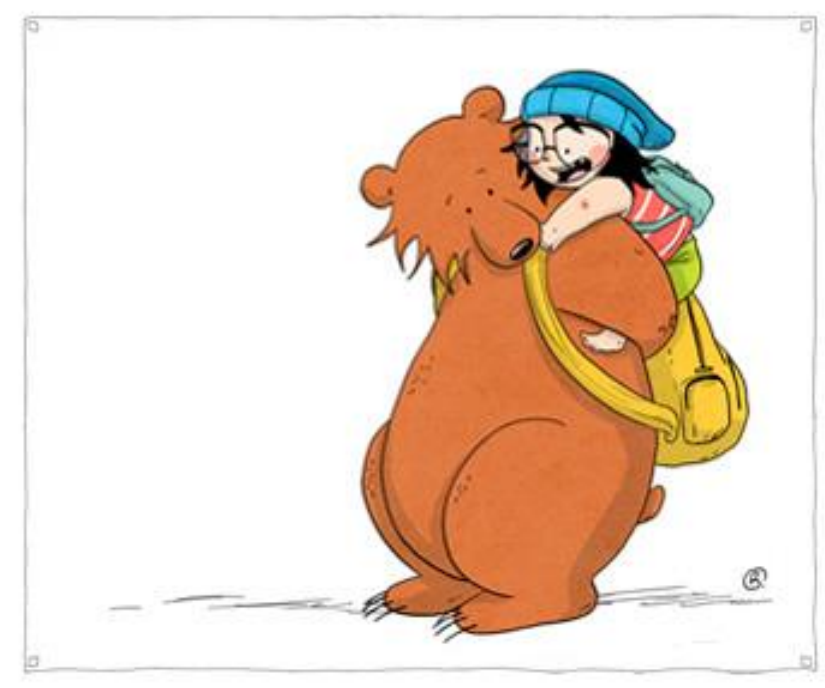

Fonte: http://bear-pt.tumblr.com/ 
Quimera (Cris Peter e Dika Araújo): A webcomic de ficção Quimera é publicada pela plataforma de streaming Social Comics, em que o leitor paga para ter acesso mensal a um acervo de conteúdos. Cris Peter é responsável pelo roteiro e cores, enquanto Dika Araújo faz os desenhos. Na história, duas mulheres, Nicole e Anna, têm as vidas interligadas após descobrirem um poder que as transforma em um ser apelidado de Quimera.

Figura 19 - Cartaz da HQ Quimera, de Cris Peter, responsável pelo roteiro e colorização

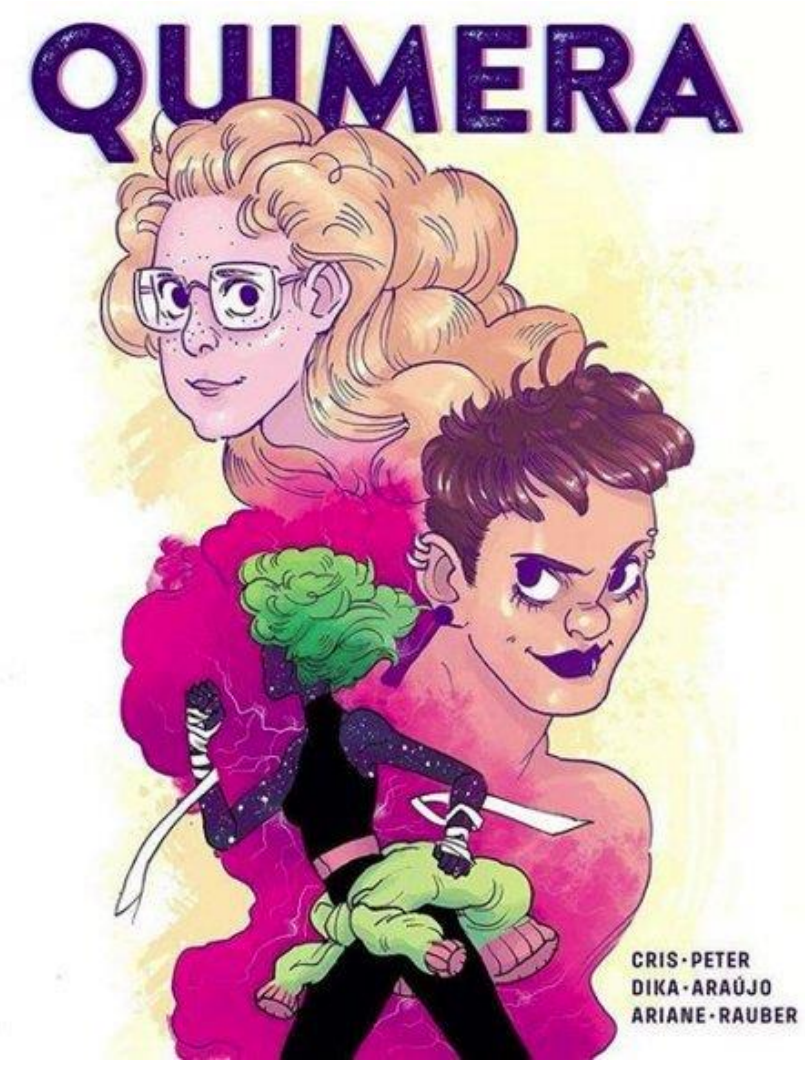

Fonte: https://www.socialcomics.com.br/

Bete vive (Lita Hayata): A história da webcomic Bebe Vive é sobre uma mulher adulta que tenta se virar aos trancos e barrancos e recebe a visita da personagem Morte, que passa a morar com ela. 
Figura 20 - Fragmento da HQ Bete Vive, de Lita Hayata

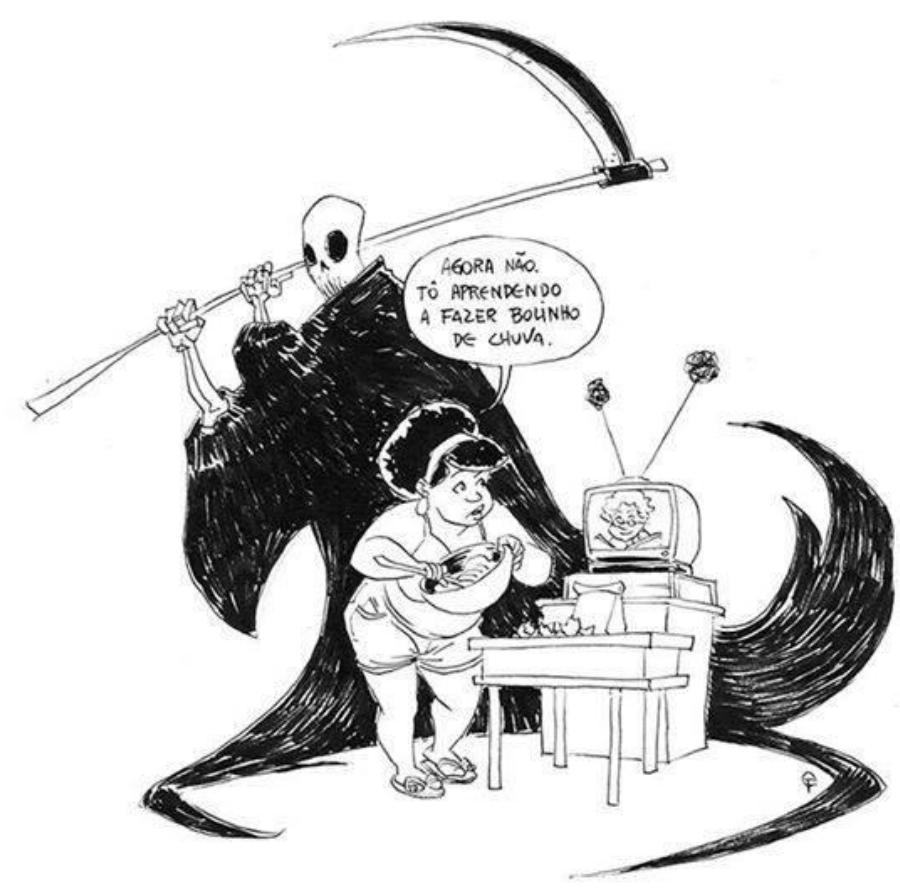

Fonte: http://betevive.tumblr.com/

Garota Siririca (Gabriela Masson - lovelove6): A webcomic começou a ser publicada online no site da Revista Samba e hoje é publicada no site da autora. A história gira em torno de uma personagem que parte em uma jornada de autoconhecimento através da descoberta da masturbação (chamada popularmente de siririca). Eventualmente se mete em algumas confusões por estar viciada na prática. 
Figura 21 - Fragmento da HQ Garota Siririca, de Gabriela Masson
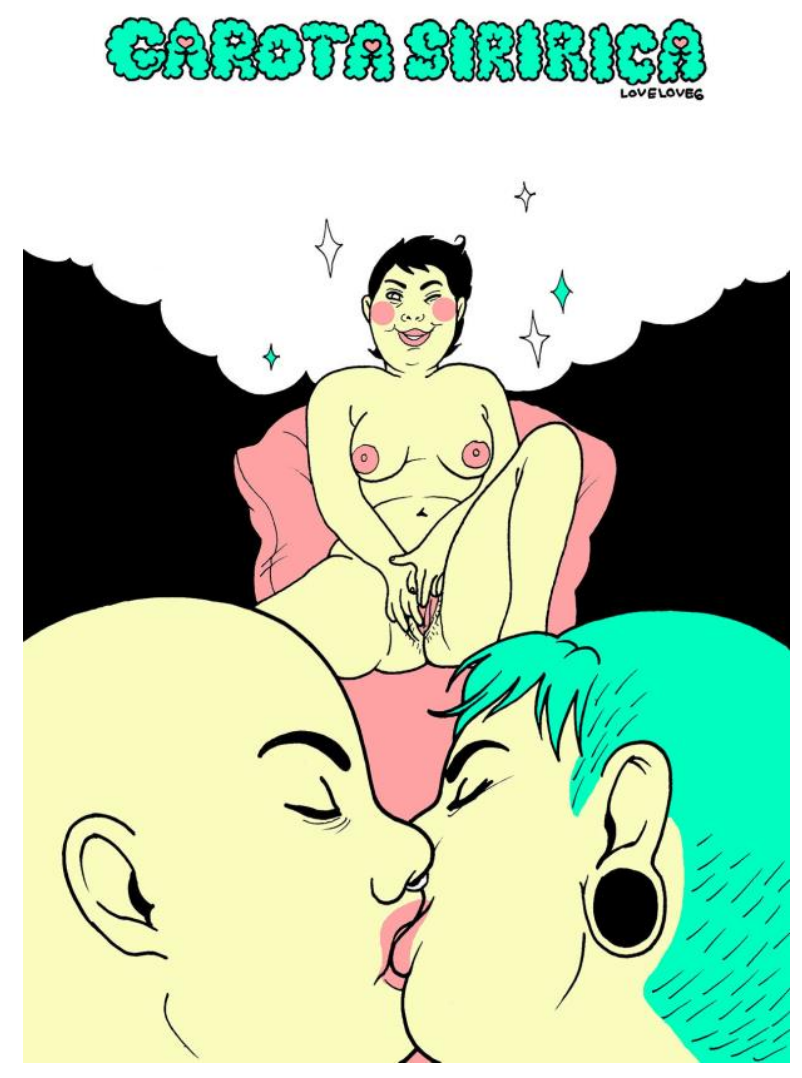

Fonte: http://www.garotasiririca.com/

"Como eu realmente..." (Fernanda Ferreira - Fernanda Nia): webcomic sobre a personagem Niazinha, que imagina várias situações agindo de acordo com a própria vontade, enquanto a "vida real" não permite digressões. Também publica situações do cotidiano de maneira cômica. 
Figura 22 - Fragmento da HQ Como eu realmente..., de Fernanda Ferreira

\section{Eu lendo romances antigamente:}

Ele luta pelo amor dela sem aceitar um "não", sem desistir! Escreveu mil cartas até receber a resposta! Bateu em todos os caras que fizeram mal a ela! fica observando ela dormir! OMG, agora ele tá prendendo ela contra a parede e vai roubar um beijo!

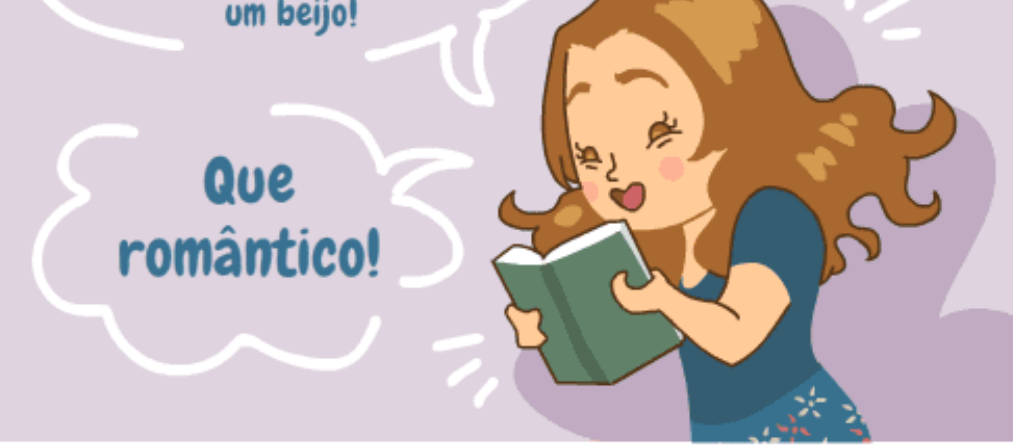

\section{Como eu realmente os leio hoje:}

Ele luta pelo amor dela sem aceitar um "não", sem desistir... Escreveu mil cartas até receber a resposta... Bateu em todos os caras que fizeram mal a ela... fica observando ela dormir... Agora ele tá prendendo ela contra a parede e vai roubar um beijo...?!

\section{Que babaca violento, machista e assustador em um nivel doentio de obsessão!}

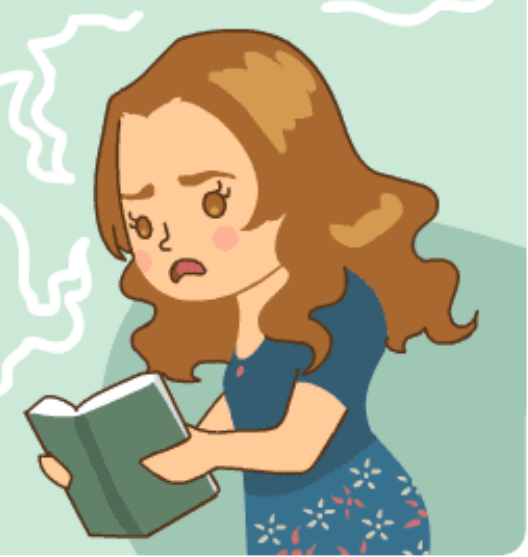

Fonte: http://www.comoeurealmente.com/

Manual de sobrevivência à vida adulta (Brendda Costa Lima): é uma história sobre ser mulher e sentir ansiedade. É sobre "crescer, ter chefes ruins, chegar ao fim do mês sem grana é algo tão comum pra personagem quanto os gatinhos fantasmas que falam com ela”, de acordo com a autora. 
Figura 23 - Fragmento da HQ Manual de sobrevivência à vida adulta, de Brendda Costa Lima
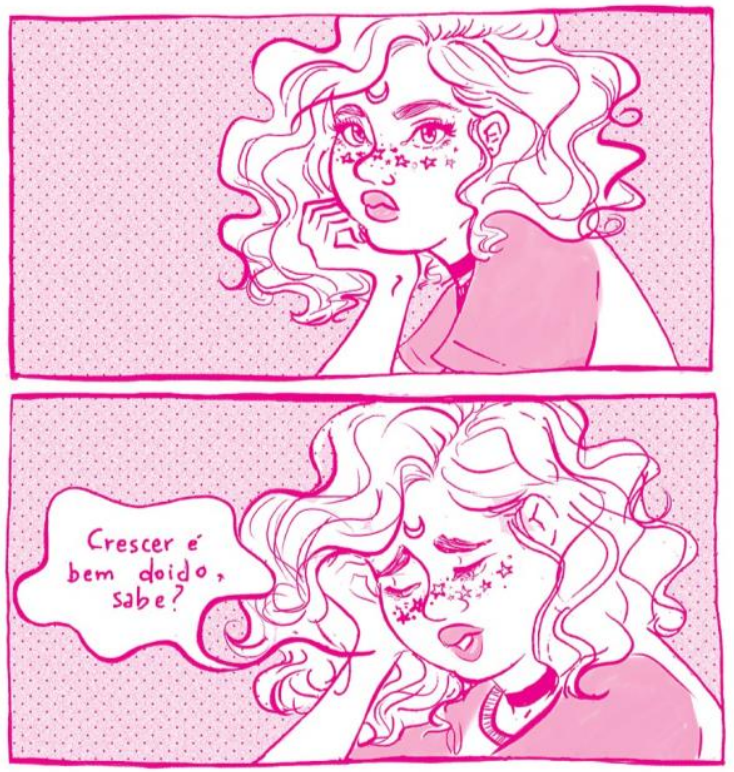

Fonte: https://medium.com/@brenddacostalima/manual-de-sobreviv\%C3\%AAncia\%C3\%A0-vida-adulta-d0e0e5f9d24b

O diário de Virgínia (Cátia Ana): O Diário de Virgínia é uma história com traços autobiográficos onde a personagem Virgínia lida com seus medos e conflitos internos ao dialogar com eles transmutados em personagens que aprecem fantasmas. Ela entra em profunda tristeza após terminar um relacionamento amoroso, mas encontra uma jornada de autoconhecimento para superar as adversidades.

Figura 24 - Cartaz da Virgínia, de Cátia Ana

Fonte:

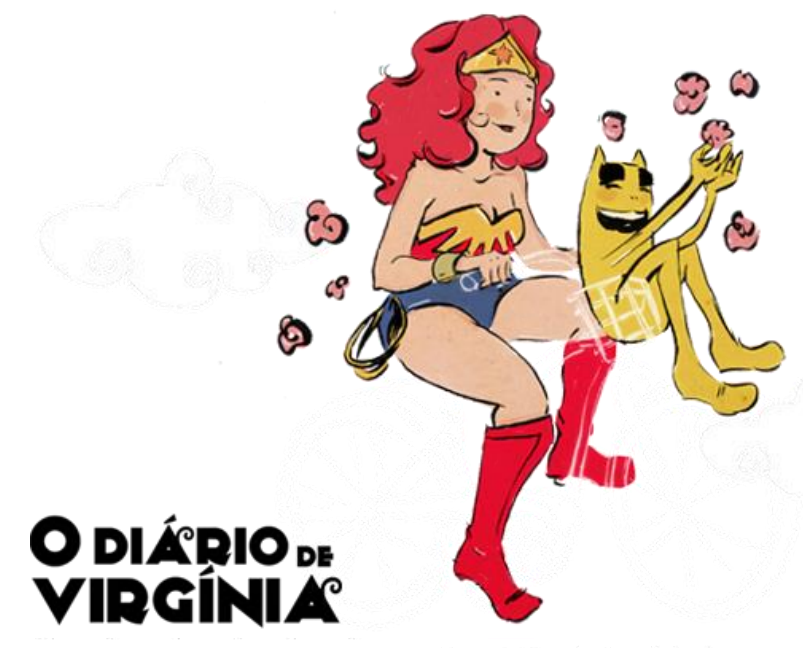

HQ $O$ diário de 
Lizzie Bordello e as Piratas do Espaço (Germana Viana): Quatro piratas mulheres, cada uma com uma personalidade marcante, moram em uma nave espacial. A missão delas é enfrentar os vilões que aparecem no caminho e que, em geral, são machistas e homofóbicos, com planos de dominar o universo.

Figura 25 - Fragmento da HQ Lizzie Bordello e as Piratas do Espaço, de Germana Viana

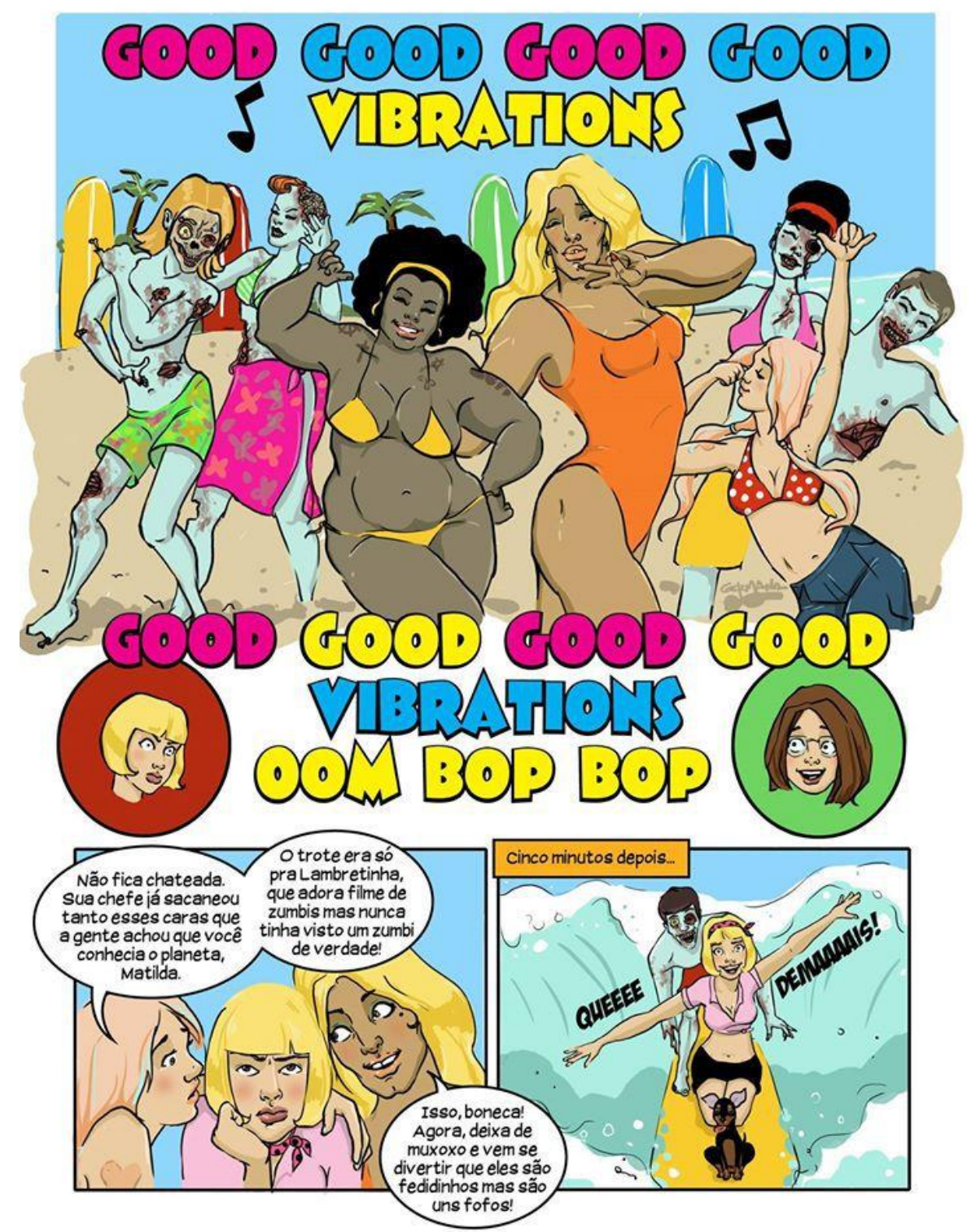

Fonte: http://www.lizziebordello.com/ / https://www.socialcomics.com.br/lizzie-bordello-e-as-piratas-doespaco/1

Abaixo, elaboramos uma tabela que resume os principais temas encontrados nas webcomics, que são: amizade; vida adulta - trabalhos e estudo; morte; amigo imaginário; sexualidade; gênero; drogas; auto estima / ansiedade e relacionamento amoroso. 
Quadro 2 - Temáticas abordadas pelas autoras

\begin{tabular}{|c|c|c|c|c|c|c|c|c|}
\hline TEMA & $\begin{array}{l}\text { BIANCA } \\
\text { PINHERO }\end{array}$ & $\begin{array}{c}\text { CRIS } \\
\text { PETE } \\
\mathbf{R}\end{array}$ & $\begin{array}{c}\text { LITA } \\
\text { HAYATA }\end{array}$ & $\begin{array}{l}\text { GABRIELA } \\
\text { MASSON }\end{array}$ & $\begin{array}{l}\text { FERNANDA } \\
\text { FERREIRA }\end{array}$ & $\begin{array}{c}\text { BRENDDA } \\
\text { COSTA } \\
\text { LIMA }\end{array}$ & $\begin{array}{c}\text { CÁTIA } \\
\text { ANA }\end{array}$ & $\begin{array}{c}\text { GERMANA } \\
\text { VIANA }\end{array}$ \\
\hline AMIZADE & $\mathrm{X}$ & $\mathrm{X}$ & $\mathrm{X}$ & & & $X$ & & $X$ \\
\hline $\begin{array}{l}\text { VIDA ADULTA/ } \\
\text { TRABALHO/ } \\
\text { ESTUDOS }\end{array}$ & & & X & X & X & X & & \\
\hline MORTE & & $\mathrm{X}$ & $X$ & & & & & \\
\hline $\begin{array}{c}\text { AMIGO } \\
\text { IMAGINÁRIO }\end{array}$ & & & $X$ & & & $\mathrm{X}$ & & $\mathrm{X}$ \\
\hline SEXo & & & & $\mathrm{X}$ & & & & \\
\hline GÊNERO & & & & $X$ & & & & $X$ \\
\hline DROGAS & & & & X & & & & \\
\hline $\begin{array}{l}\text { AUTO ESTIMA / } \\
\text { ANSIEDADE }\end{array}$ & & & $X$ & & & X & X & X \\
\hline $\begin{array}{l}\text { RELACIONAMEN } \\
\text { TO AMOROSO }\end{array}$ & & & & & $X$ & & $X$ & \\
\hline
\end{tabular}

Fonte: A autora (2018)

Descreveu-se como cada tema se desenvolve nas HQs, padrões e contradições:

a) Amizade: O tema aparece em 6 das 8 webcomics, com destaque em Bear, Quimera, Garota Siririca e Lizzie Bordello, em que é central nas narrativas. Em 4 delas é valorizada a amizade entre mulheres. São amigas que dividem emoções, medos e se apoiam mutuamente, como em Garota Siririca, em que a personagem central tem a amiga inseparável, Xoxola, com quem desabafa sobre o vício em masturbação. Em Quimera, Anna e Nicole, as protagonistas, precisam se juntar para derrotar os vilões, se fundindo em uma criatura com superpoderes. Em Lizzie Bordello, as piratas são quatro amigas que comandam uma nave espacial: Lizzie Bordello (a capitã), Fran (oficial de comunicações, que aparenta ser transexual), Lambretinha (a novata) e Deus (não tem uma função definida). Em Bear, que é uma HQ infanto-juvenil, a amizade 
improvável entre Raven e o mal-humorado urso Dimas é o que orienta o enredo.

Figura 26 - HQ Bear, de Bianca Pinheiro, aborda a amizade entre uma garotinha e um urso

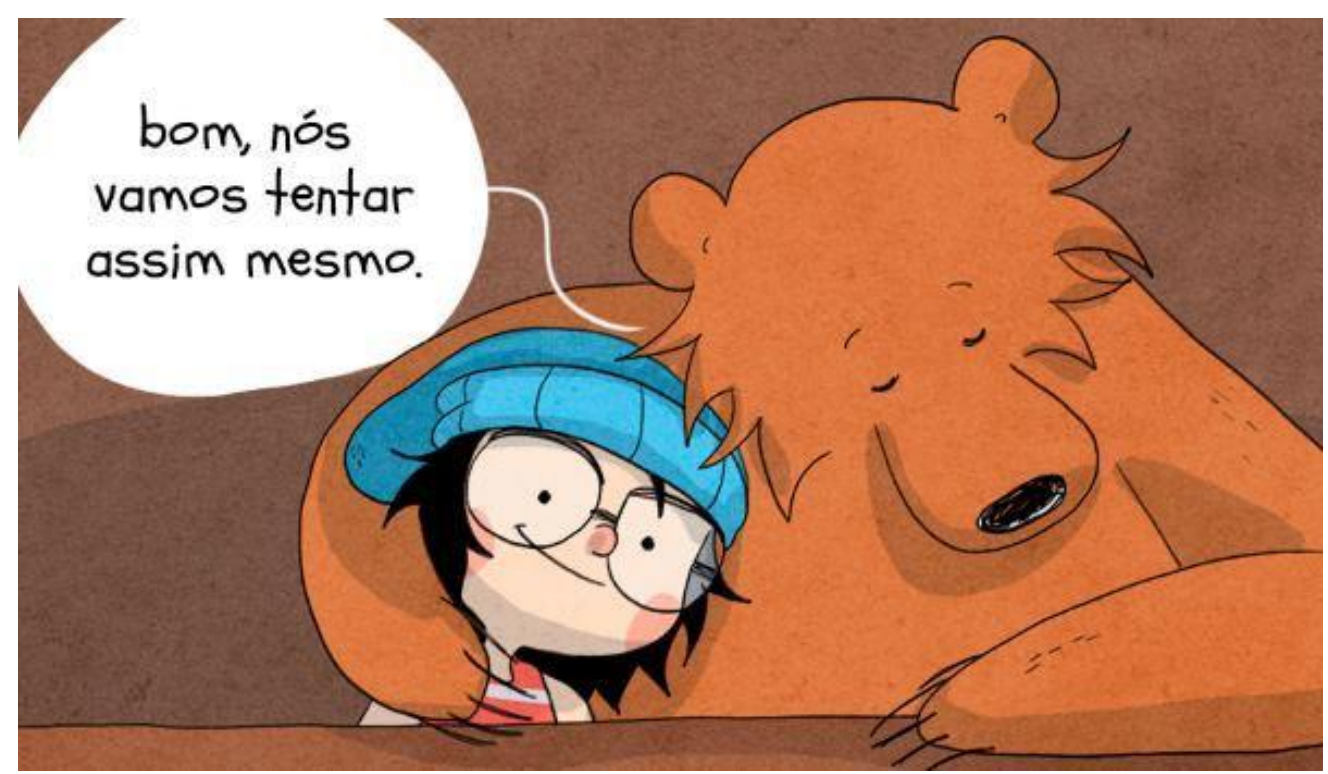

Fonte: http://bear-pt.tumblr.com/

b) Trabalho/Estudos: É o segundo tema mais recorrente, com destaque para a webcomic Manual de Sobrevivência da Vida adulta, em que é central. A personagem relata as vantagens e desvantagens de ser independente, morar sozinha, e ter que lidar com muitas responsabilidades. Em Garota Siririca, a protagonista trabalha com informática, em casa, o que acaba alimentando o vício em masturbação. Niazinha, em Como eu realmente... relata os momentos de estudo, em que tem que lidar com vestibular, provas e faculdade e, em geral, se sente cansada por ter tantas responsabilidades. A história de Bete vive começa com a protagonista tendo problemas por não conseguir pagar as contas. É nessa hora que a personagem que representa a morte começa a importuná-la.

c) Morte: A webcomic Quimera narra o episódio em que Nicole morre durante um assalto, depois de levar um tiro. Anna consegue "ressuscitar" a garota com os poderes que carrega, embora ela volta como uma espécie de fantasma. Em Bete vive, a morte é uma personagem humanizada, que assombra a protagonista Bete, aparecendo em momentos aleatórios. A morte é representada com um rosto de caveira e um vestido preto. Embora tenha um 
aspecto hostil, ela acaba se tornando uma companhia para Bete, que vive sozinha, e faz comentários que provocam a protagonista a refletir sobre a própria vida.

Figura 27 - A personagem Bete, criada por Lita Hayata,

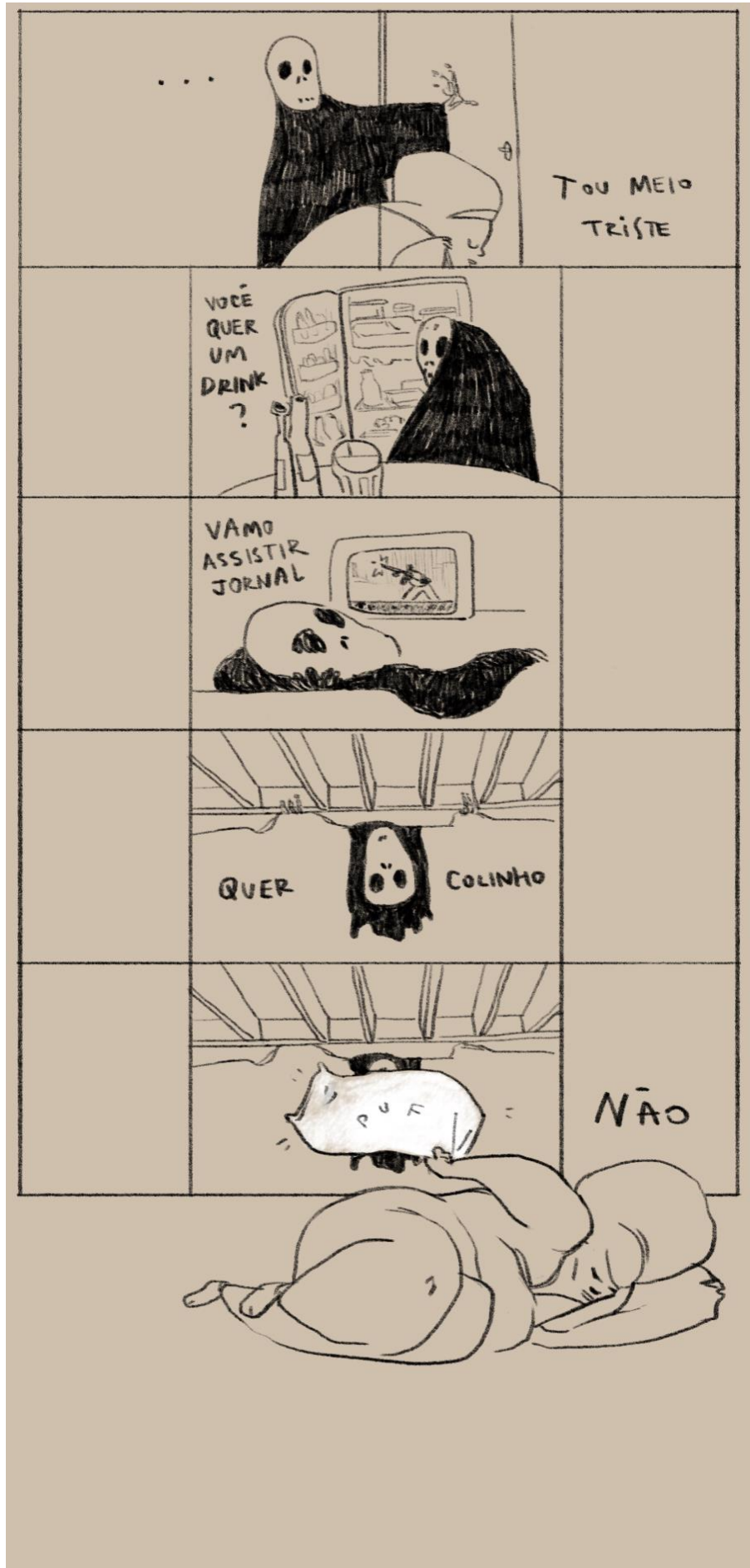

Fonte: http://betevive.tumblr.com/ 
d) Amigo imaginário: Em 3 webcomics aparecem personagens inumanos que conversam com as protagonistas, em geral, nos momentos em que estão angustiadas. Representam uma espécie de alter ego, que ora criticam e ora dão conselhos. Em Bete vive a morte é o amigo imaginário, irônico, que aponta os defeitos da personagem, que parece levar a vida de forma negligente. Em Manual de Sobrevivência da Vida adulta, a protagonista é atormentada por fantasminhas em forma de gatos que aparecem para apontar defeitos e cobrar uma postura mais adulta da garota. Em $O$ diário de Virgínia ocorre algo semelhante, pois a protagonista, que está numa espécie de depressão no início do enredo, começa a ser perseguida por um fantasma, que a impede de sair daquela situação.

Figura 28 - Personagem Virgínia, criada por Cátia Ana

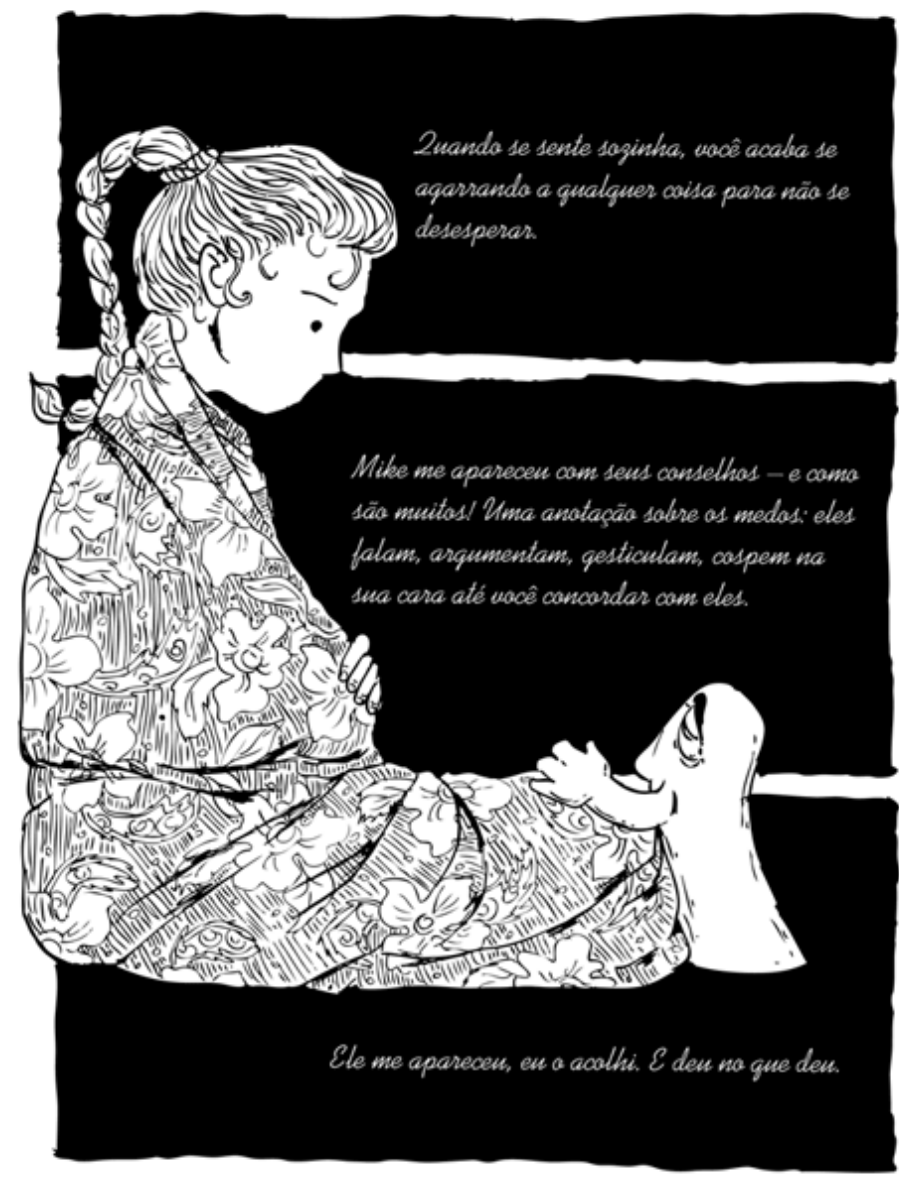

Fonte: http://www.odiariodevirginia.com/ 
e) Sexo: a descoberta do prazer sexual é o tema central em Garota Siririca. A personagem central é uma adolescente que descobre as maravilhas da masturbação como forma de prazer e de autoconhecimento. Ela descobre, no início da webcomic, que o machismo impede que as meninas conheçam o próprio corpo e descubram a sexualidade por meio da masturbação. Contrariando esse preconceito, se torna viciada em siririca (nome popular para masturbação) e encontra amigas que falam abertamente sobre o assunto.

f) Gênero: Em Garota Siririca, a descoberta da própria sexualidade vem acompanhada da relação de amizade com mulheres lésbicas e, inclusive, a protagonista se envolve com uma delas. O assunto é abordado com naturalidade, sem relação de conflito, nem angústia. Em "Lizzie Bordello" existe uma preocupação em apresentar a diversidade de gênero. Há personagens gays, lésbicas e uma das protagonistas aparenta ser transexual.

g) Drogas: Em Garota Siririca, o uso de maconha está relacionado à ampliação do prazer da protagonista em se masturbar. Em vários momentos ela aparece fumando e não há uma relação conflituosa com esse hábito, é apenas uma forma de relaxamento e entretenimento. 
Figura 29 - Personagem de Garota Siririca, HQ de Gabriela Masson, é usuária de maconha

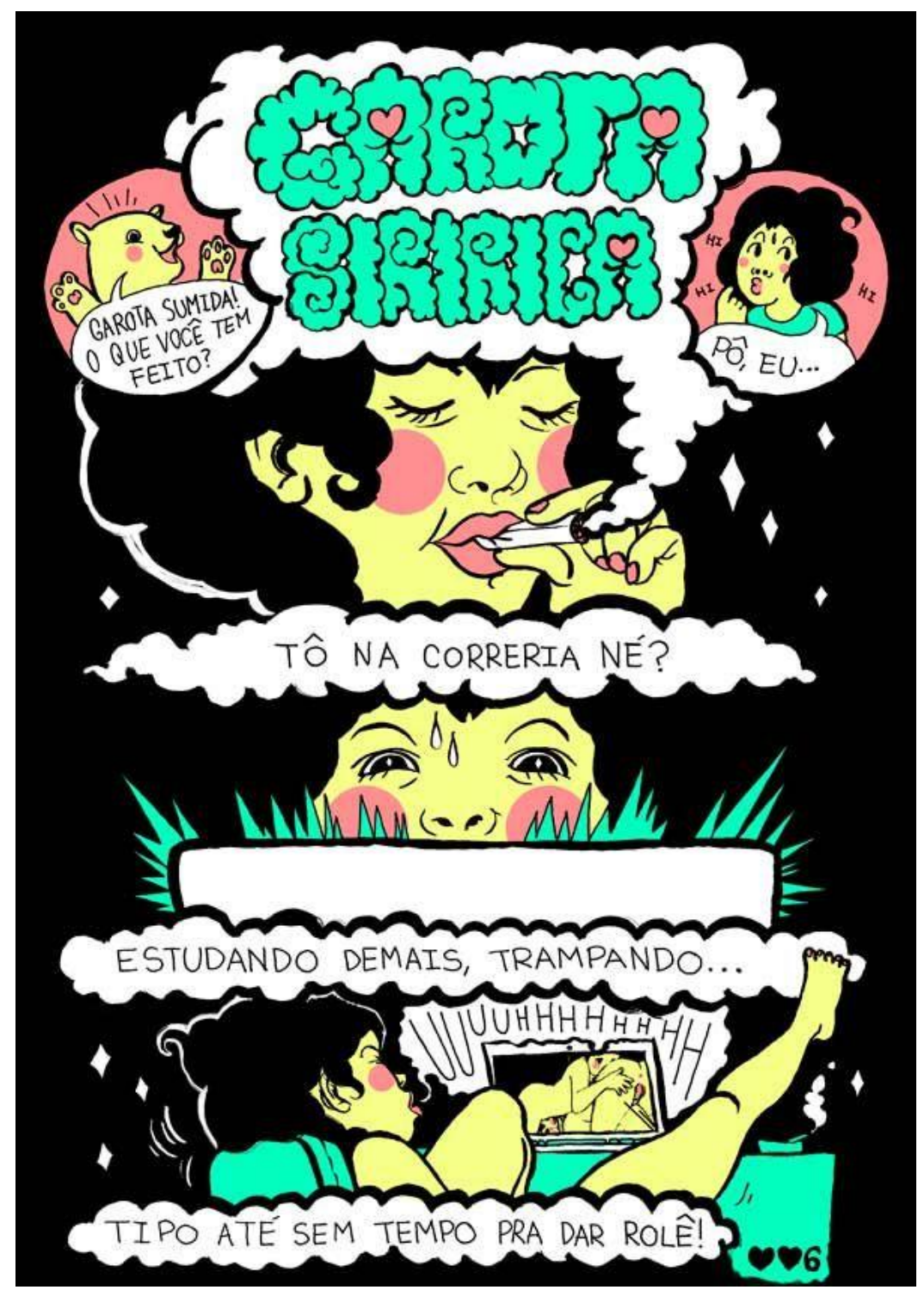

Fonte: http://www.garotasiririca.com/

h) Auto estima / Ansiedade: Em 3 webcomics, a autoestima das protagonistas é frágil, vem acompanhada de muita ansiedade e medo. Em Bete vive e Manual de sobrevivência à vida adulta, os principais motivos que geram ansiedade $\mathrm{e}$ tristeza envolvem lidar com a vida adulta, as contas a pagar, os prazos a cumprir e a solidão gerada no processo. Em Lizzie Bordello, no entanto, há momentos em que a autoestima das personagens se mostra elevada, sobretudo quando a personagem Deus rouba a cena. Ela é uma mulher autoconfiante e tem um corpo fora dos padrões, o que não é fator de angústia. 
Relacionamento amoroso: O tema aparece em 2 webcomics, de forma episódica. Em $O$ diário de Virgínia, é o rompimento de uma relação que serve como gatilho para que a protagonista mergulhe em uma tristeza profunda e, depois, em uma busca por se reinventar. Em "Como eu realmente..." a protagonista Niazinha tem um namorado que compartilha de interesses parecidos com ela em uma relação harmoniosa.

Em relação à análise de temas, a tabela nos permite visualizar que o tema mais recorrente, que aparece em seis HQs é a amizade. Em geral, enfatizam a importância da amizade - sobretudo entre mulheres, com exceção das HQs Bear e Bete vive, em que as protagonistas são amigas de seres imaginários -, do apoio mútuo para que as personagens possam superar crises (existenciais ou externas), além de retratarem as eventuais divergências de opinião, comuns em qualquer relação.

Se a história dos quadrinhos mainstream do século XX é marcada pela presença frequente de assuntos ligados a relacionamentos amorosos heterossexuais, desde os quadrinhos feitos para o público feminino até as HQs de super-heróis, nas webcomics selecionadas esse não parece ser um tema de grande atenção. Em "Como eu realmente" as relações ou idealizações de parceiros homens aparecem de forma esporádica, em tom de humor. Em Garota Siririca as relações que envolvem amor e, sobretudo, sexo, são centrais, e o foco não é heterossexual porque a protagonista é lésbica.

Outro ponto interessante são os personagens imaginários que acompanham as protagonistas em Bete vive, Manual de sobrevivência à vida adulta e $O$ diário de Virgínia. Na primeira HQ, esse personagem é a Morte, que aparece de repente para assombrar a protagonista, no sentido de trazer à tona questões espinhosas, obrigando-a refletir sobre as próprias decisões; na segunda, são fantasmas felinos pessimistas que aparecem para atormentar a personagem central em momentos de conflito existencial; na terceira, também são fantasmas que ficam à espreita criticando os passos de Virgínia. Esses personagens imaginários, que são vistos apenas pelas protagonistas e não interagem com outras figuras, parecem como alter ego, um recurso narrativo muito utilizado na literatura, e que também aparece em alguns quadrinhos. Eles refletem a autocobrança das personagens e sentimento de culpa em relação às próprias decisões.

No capítulo "Elas por elas no mundo" foi possível refletir sobre as influências de artistas mulheres dos quadrinhos, cujas obras ultrapassaram as fronteiras dos países de origem, como é o caso de Maitena, Claire Bretecher, Alison Bechdel. Essas obras têm em comum a discussão sobre gênero e sexualidade, o que é evidente em duas das oito webcomics selecionadas, que são: Garota Siririca e Lizzie Bordello e as Piratas do Espaço. Em ambas, 
além da discussão sobre diferentes performances de gêneros (Butler, 1990), que ultrapassam a heteronormatividade, abordam a igualdade de gênero no viés declaradamente feminista.

No mesmo capítulo também é possível notar a predominância de HQs autobiográficas entre as escolhas de editoras independentes de quadrinhos no Brasil - Nemo, Mino, Veneta, Barricada e Quadrinhos na Cia. Dentre as obras 357 publicadas, 73 foram identificadas com autoria feminina exclusiva (51) ou partilhada (22), o que corresponde a cerca de $20,6 \%$ do universo. As obras foram categorizadas nos gêneros "ficção" (o que inclui adaptações literárias de obras ficcionais) e "não ficção" (autobiografias, biografias e enredos baseados em pesquisa histórica).

$\mathrm{Na}$ categoria de não ficção foram contabilizadas $39 \mathrm{HQs}$ com a ressalva de que "Persépolis", de Marjani Satrapi, foi dividida em 4 volumes pela Quadrinhos na Cia. Dentre as 39, 26 são apresentadas como autobiografia, 5 como histórias baseadas em pesquisa histórica e 8 são biografias de personalidades, de acordo com as descrições encontradas nos sites das editoras.

$\mathrm{Na}$ amostra das webcomics, no entanto, apenas uma é declarada pela autora como autobiográfica, que é o caso de Manual de sobrevivência à vida adulta. Cátia Ana, no questionário, define que sua webcomic tem "traços autobiográficos" e Fernanda Ferreira traz uma protagonista que dialoga com as experiências como ilustradora profissional, embora não assuma o lado biográfico. Isso sugere que na autopublicação on-line, as mulheres quadrinistas têm mais liberdade de desenvolver temas que não estão emoldurados pelas escolhas das editoras, que apostam em fórmulas que podem ter mais sucesso entre o público leitor.

O protagonismo feminino nas HQs mostra é encenado de forma muito diferente das HQs do mainstream norte-americano, cujos padrões foram reproduzidos em produções nacionais no século XX. Sedução, erotismo, papeis tradicionais de esposa e dona de casa eram representados por personagens femininas criadas para satisfazer o olhar masculino que, de acordo com Barcellos (2016), era o alvo das editoras.

Na reconstituição histórica da atuação feminina na criação de quadrinhos percebemos que existem estereótipos que enquadram o trabalho de mulheres como infantis, delicados, que abordam temas ligados à vida doméstica, relacionamento amoroso e moda. Uma questão presente na literatura revisada, envolvendo a representação do feminino nos quadrinhos, é a função de objeto do olhar masculino, sua representação elaborada pela maioria de autores homens presentes no mercado editorial.

Já no mercado underground, com o comix vendidos nas head shops norte-americanas, o traço feminino, me geral, beirava o grotesco, o escatológico, mostrando uma sexualidade 
sem glamour e experiências de abuso, como nos trabalhos de Aline Kominsky (CHUTE, 2005). A discussão sobre gênero também emergiu com HQs que retratavam o universo homossexual e questionavam os padrões heterossexuais influenciados pelo machismo. Um dos grandes nomes revelados na época foi o de Alison Bechdel, autora da série Dykes to Watch Out For.

Os trabalhos selecionados na amostra de pesquisa trazem protagonistas femininas que pouco interagem em relacionamentos com homens, exceto em "Como eu realmente..." e $O$ diário de Virgínia. Nos dois casos, os personagens masculinos são secundários, aparecendo em momentos esporádicos da narrativa.

É preciso ressaltar que grande parte dos trabalhos de mulheres que adquiriram notoriedade da era dos comix em diante são considerados autobiográficos, como fica evidente em Graphic Women, de Chute (2005). Aline Kominsky, Marjane Satrapi e Alison Bechdel, por exemplo, são autoras que escreveram graphic novels e se destacaram no mercado editorial narrando episódios da própria vida.

Ainda assim, tais obras parecem tentar romper com o lugar a princípio reservado à mulher nos quadrinhos, que é o de relatar aspectos da vida privada e doméstica. Abordam temas como marginalidade e política como parte da narrativa autobiográfica (CRIPPA, 2017). Os trabalhos das quadrinistas brasileiras na internet sugere que, sem o filtro direto das editoras, a transgressão é ainda maior, considerando que apenas uma entre as oito autoras da amostra explicita o caráter autobiográfico de sua webcomic. O que era majoritário no mercado editorial já não se faz regra no universo da autopublicação.

É preciso refletir também sobre a opção por narrativas com traços autobiográficos, o que fica evidente em três das oito obras analisadas. Nessas HQs a vida íntima e os conflitos existenciais predominam, retratando o espaço privado. $\mathrm{O}$ que explica o interesse em lidar com temas não-ficcionais e que remetem à vida privada das mulheres?

Por que o discurso feminino na cultura pop (como no cinema e quadrinhos) é "reservado" a certos tipos de temas ligados à vida privada? Em “A ordem do discurso", Foucault (1979, p. 249) analisou como "as grandes estratégias de poder se incrustam, encontram suas condições de exercício em microrrelações de poder" e como os discursos são qualificados ou desqualificados de acordo com o contexto social, político e cultural em que estão inseridos. Seria o caso de pensar em uma dinâmica que funciona em via de mão dupla, em relação às mulheres que fazem quadrinhos e as escolhas editoriais do mercado. As autoras podem tentar se encaixar em um tipo de discurso mais aceito e qualificado por quem detém o poder de decisão, ainda que de maneira inconsciente. 
Outro fator que pode ter influenciado nas escolhas das quadrinistas que abordam questões de gênero é a emergência da discussão sobre sexualidade por meio das reivindicações do movimento feminista, desde a década de 70. As feministas passaram a questionar a configuração dos espaços acadêmicos e artísticos, tomando como ponto de partida a discussão de que o privado também é político, já que as estratégias de poder se incrustam no corpo feminino, através de coerções (MACEDO, 2006). 


\section{CONSIDERAÇÕES FINAIS}

Chenault (2007) buscou refletir sobre a atuação feminina nas editoras de quadrinhos norte-americanas no século XX, quando essa arte começou a fazer parte da cultura pop daquele país, o que influenciou a imprensa e editoras no Brasil. Embora a trajetória do mercado de quadrinhos tenha nos Estados Unidos tenha muitas particularidades, com a existência de um esquema industrial de produção, é possível dizer que as considerações de Chenault (2007) se aproximam da realidade de atuação feminina no Brasil, em relação ao trabalho "às margens".

As pioneiras norte-americanas, mostram que as mulheres sempre estiveram nas editoras, embora não tenham alcançado sucesso na mesma proporção que desenhistas e roteiristas homens. Com os trabalhos da quadrinista e historiadora Trina Robbins, o trabalho das pioneiras foi resgatado e registrado em seus livros. Trina e outras quadrinistas que passaram a produzir quadrinhos underground, a partir da década de 1960, também se atentaram para a exclusão das mulheres, formando coletivos que resultaram na produção das coletâneas It ain't me Babe e Wimmen's Comix.

$\mathrm{Na}$ era dos comix, as HQs com temáticas adultas passaram a lidar com abordagens "adultas, identitárias, experimentais e confessionais" (CHUTE, 2010, p. 14), o que pode ter aproximado o público feminino, que antes consumia quadrinhos de super-heróis que privilegiavam os leitores homens, por vezes, com viés sexista. Também foi na época dos comix que surgiram as primeiras revistas sobre o mundo gay e lésbico.

A partir da década de 1990, Robbins (2009) afirma que nunca houve uma época em que as mulheres produziram tanto. As artistas passaram a produzir de modo independente, imprimindo seus próprios fanzines ou publicando seus quadrinhos online.

A trajetória dos quadrinhos no Brasil foi fortemente influenciada pelo mercado norteamericano no século $\mathrm{XX}$, o que se prolonga até hoje, com a popularização das franquias de super-heróis da Marvel e DC Comics, embora haja espaço no mercado para outros tipos de publicações, como as HQs franco-belgas e latino-americanas.

A atuação das mulheres como criadoras de histórias em quadrinhos, no início do século XX estava vinculada à imprensa burguesa ou ligada movimentos políticos e artísticos de vanguarda. Há poucos registros sobre personalidades femininas marcantes da época, mas, entre as pioneiras das artes gráficas, podemos destacar os nomes Nair de Teffè, Patrícia Galvão, a Pagu, e Hilde Weber. A década de 1970 é marcada pelo lançamento de revistas 
alternativas, como O Pasquim, Balão e $O$ Bicho. As mulheres atuaram junto a essas publicações como exceções dentro de ambientes dominado por homens e, hoje, o registro de suas obras não é de fácil acesso. Marisa Dias Costas, Crau da Ilha e Ciça são nomes que se destacaram nas revistas e na imprensa.

A discussão sobre a falta de autoras mulheres nos quadrinhos é afirmada no século XXI, com a criação da coletânea "As Periquitas", organizada pela artista Crau da Ilha. Mais tarde, em 2010, o coletivo Lady's Comics foi criado para dar visibilidade às mulheres por meio dos recursos da internet e das redes sociais.

Boff (2014) observa que a inserção da mulher no mercado de quadrinhos foi mais expressiva nos Estados Unidos e Japão, os grandes países produtores de quadrinhos no mundo. O Japão é uma referência em termos de produção feminina, com coletivos de artistas que se popularizaram no país e fora dele, como, por exemplo, o CLAMP, formado por quatro mulheres, ainda na década de 1980. Grande parte das autoras contemporâneas de webcomics declararam, em entrevista durante o $2^{\circ}$ Encontro Lady's Comics, em Belo Horizonte, terem iniciado a leitura de quadrinhos por meio dos mangás vendidos em bancas de jornal. $\mathrm{O}$ contato com trabalhos femininos de outras nacionalidades aparece de forma tardia, com a leitura de graphic novels.

A personagem Luluzinha criada pela norte-americana, Marjorie Buell, teve grande aceitação entre o público brasileiro, que teve acesso aos gibis da série e desenhos animados. A personagem Mônica criada por Mauricio de Sousa, embora não tenha sido criada por uma mulher, também foi decisiva durante a formação das quadrinistas que publicam hoje. São duas representações femininas que contestam os padrões de comportamento dócil e delicado associado às mulheres, são garotas corajosas, inteligentes e que sabem se defender.

Entre os nomes proeminentes dos quadrinhos adultos que chegaram às livrarias brasileiras, é possível notar que suas produções ora se aproximam e ora se afastam do lugar reservado à produção feminina, que é o da vida privada e doméstica, como explica Crippa (2017), que usa como referência o cânone literário. É o caso das artistas Alison Bechdel, Julia Wertz, Marjane Satrapi, Ulli Lust e Anne-Charlotte Gauthier. Anteriores a essas autoras, a francesa Claire Bretécher e a argentina Maitena abordaram questões de gênero e de "ser mulher" num mundo machista, contestando os padrões de feminilidade.

Não só nos quadrinhos essas representações eram recorrentes, mas também no cinema. O Instituto Geena Davis, ONG que há mais de 20 anos se dedica a estudos sobre desigualdade de gênero no audiovisual, aplica uma metodologia de análise de filmes chamada Bechdel Test (Teste de Bechdel), em homenagem a uma tira da quadrinista Alison Bechdel, na série 
"Dykes to Watch Out For", publicada em jornais e revistas voltados a assuntos LGBTs, entre as décadas de 1980 e 2000. Na metodologia do Teste de Bechdel, os filmes são classificados, em termos de igualdade de gênero, a partir de três perguntas simples: Há duas personagens femininas com nome? Elas conversam entre si? Falam sobre algum assunto que não seja homem? Se as três perguntas forem respondidas positivamente, o filme recebe o selo "Arating", que também vem sendo aplicado em outros produtos audiovisuais, como programas de rádio e televisão (CASTILHO, 2016).

As autoras da amostra que publicam na internet dominam todos os processos de produção e edição das HQs, do roteiro à colorização, mostrando uma diversidade de técnicas e estilos. A autopublicação é uma forma que artistas encontram para que o trabalho possa chegar a mais leitores, sem necessidade de mediação, num cenário que Jenkins (2008) denominou como "era da convergência". A convergência promove o que ele chama de "cultura participativa e inteligência coletiva" em torno de interesses comuns (JENKINS, 2008, p. 27).

É comum ver quadrinistas divulgando o trabalho nas redes sociais, links para financiamento coletivo, sorteio de originais, agenda de eventos que participam sobre quadrinhos, tudo para dar visibilidade ao que produzem, numa espécie de autopromoção. Publicar online também pode ser uma faca de dois gumes. Por um lado, as redes sociais, como Facebook, Instagram e Twitter, são a principal forma de divulgação do trabalho, de acordo com as autoras entrevistadas. Por outro, as regras de alcance das publicações mudam repentinamente e, cada vez mais, o conteúdo precisa ser patrocinado para ser visto pelos usuários em suas timelines. Os grupos e fanpages nessas mesmas redes, que reúnem pessoas interessadas no universo dos quadrinhos, acabam tendo o papel fundamental de divulgação. Do contrário, muitas mulheres artistas estariam condenadas a falarem "para si mesmas" e para um grupo muito restrito de amigos e familiares.

Plataformas como o Lady's Comics e Zine XXX foram agentes mediadores importantes para as artistas que começaram a publicar quadrinhos, numa história recente que começa em meados de 2010. Além de dar visibilidade a muitos trabalhos de mulheres e criarem registros para que eles não fossem esquecidos com o tempo, a iniciativa do Lady's Comics também agiu como uma instância legitimadoras, que atesta a qualidade das produções femininas, no papel de mídia especializada em quadrinhos.

Iniciativas como essa atuam como mediadoras culturais que influenciam em questões estéticas, artísticas, culturais e dos saberes compartilhados, como propõe Davallon (2003). Mediar os saberes compartilhados é um processo que vem se intensificando na era da 
convergência dos meios digitais, que une pessoas em torno de interesses comuns (JENKINS, 2008).

A mediação cultural que influencia em questões artísticas e estéticas também pode ser discutida, afinal, quando o coletivo Lady's Comics atesta a qualidade de trabalhos femininos, acaba por valorizar as escolhas estéticas presentes que, por vezes, se diferenciam de produções masculinas. Por exemplo, o levantamento bibliográfico sobre a atuação feminina na história dos quadrinhos norte-americanos sugere que o traço das mulheres que atuaram em editoras e na imprensa era tachado de fofo, delicado, infantil. No entanto, é preciso questionar: essas são características ruins ou pejorativas? Isso deve comunicar apenas às leitoras mulheres? São questões que merecem ser aprofundadas em um outro estudo sobre as representações artísticas de mulheres nos quadrinhos. Por ora, nos preocupamos em discutir as instâncias legitimadores do trabalho de mulheres que produzem webcomics, a partir das considerações que elas mesmas forneceram ao responderem o questionário apresentado.

Entre as quadrinistas da amostra, a maioria concorda que instâncias como premiações, eventos e a mídia especializada são fundamentais para que seus trabalhos tenham visibilidade e reconhecimento. Apenas publicar na internet não garante que o trabalho irá repercutir, o que diminui as chances das autoras de desenvolverem a carreira nos quadrinhos.

As premiações, como o Troféu HQMIX, parecem contribuir para a continuidade do trabalho, considerando que a maioria das autoras da amostra venceram ou foram indicadas ao prêmio. Bianca Pinheiro, Germana Viana e Cris Peter, são exemplos de mulheres premiadas e que, ao mesmo tempo, possuem uma carreira sólida no mercado de quadrinhos e ilustração. Bianca trabalhou para a Mauricio de Sousa Produções, Germana atua como agente que indica nomes para o mercado internacional e Cris Peter já trabalhou com a Marvel, DC Comics, além de ter sido a primeira brasileira indicada ao Eisner Awards, a maior premiação norteamericana de HQs, como colorista - nesta pesquisa, ela ganhou destaque por sua produção online como roteirista, alguém que protagoniza o processo de criação do enredo e dos personagens.

Ao questionarmos a sobre a lacuna de representatividade das quadrinistas precisamos refletir sobre o que tornaria essa representatividade possível, caminhos que sugerem para ampliar o alcance e reconhecimento das produções. Questionadas sobre isso, as autoras entrevistadas apontaram dois caminhos: o editorial e o numérico, que funcionam como uma via de mão dupla.

As escolhas editoriais envolvem não só contratar artistas para publicações em editoras, mas, também, participarem de coletâneas, curadoria de eventos e premiações. "Atualmente 
acho que principalmente nós reivindicamos curadorias editoriais preocupadas em compensar o machismo histórico do mercado e em valorizar e incentivar os trabalhos de jovens autoras", afirmou Gabriela Masson. Outra questão é a presença majoritariamente masculina entre os editores e, como acrescenta Fernanda Nia, entre os críticos de quadrinhos: "a grande maioria da crítica é masculina. A editoração é feita por homens e com um olhar masculino. [...] Se o quadrinho é fofo, ou trata de cotidiano feminino, por exemplo, eu vejo uma tendência a considerá-lo como inferior".

Bianca Pinheiro aponta outro caminho para a questão editorial, que é o da adequação de uma HQ às temáticas que rendam alguma repercussão: "Posso estar muito enganada, mas acredito que o reconhecimento de um trabalho ocorre quando ele consegue se encaixar em alguma categoria de coisas que fazem algum sucesso no momento". Nessa perspectiva, a influência de escolhas editoriais baseadas em gênero, não se aplica, embora a autora reconheça que ainda existe um número muito maior de homens produzindo quadrinhos do que mulheres.

O outro caminho apontado para explicar as diferenças de atuação entre os gêneros é o numérico, no sentido de que "o número de publicações produzidas por homens é maior", como acredita Lita Hayata. Sobre essa discussão, é preciso considerar que existem diferenças no modo de produção de HQs de super-heróis, que consiste em um dos polos, e do outro, os quadrinhos autorais. O mercado de quadrinhos de heróis é historicamente marcado pelas editorias masculinas e voltado para o público masculino, como destaca. Trina Robbins tem um trabalho de recuperação das informações sobre artistas e roteiristas que atuaram no mercado norte-americano e que sofreram uma espécie de apagamento histórico. Nesse sentido, é possível pensar na naturalização da presença masculina dentro das editoras e da produção de HQs de heróis.

Por outro lado, no campo dos quadrinhos autorais, que não possui critérios fixos de produção, é possível pensar em uma maior atuação feminina, embora seja difícil encontrar dados precisos. "Se o reconhecimento for em um mercado como o de super-heróis americanos, imagino que o caminho seja desenhar, escrever e colorir como se espera no mercado. Em matéria de quadrinho autoral, é difícil saber”, observa Bianca Pinheiro.

A desigualdade numérica é tratada pelas entrevistadas como um fim, como algo que perpetua a desigualdade de atuação no mercado ou como consequência direta do machismo estrutural, que inibe a presença feminina de produzirem e de projetarem uma carreira profissional. 
A divulgação na imprensa, sobretudo por meio de sites especializados em quadrinhos ou que agreguem um nicho de público relacionado ao que as autoras produzem é considerada importante, de forma unânime. O principal ponto levantado é a importância da indicação da imprensa como forma de legitimação, não apenas como divulgação de um trabalho. "É importante para me legitimar como autora, fazer o registro do meu trabalho e compartilhar com o público as minhas reflexões sobre os quadrinhos que ele tem lido", destaca Gabriela Masson. Outro aspecto é o incentivo para que outras mulheres produzam quadrinhos, como enfatiza Cris Peter: "Quanto mais mulheres e meninas tiverem conhecimento da minha existência no mercado, mais elas verão a possibilidade de também seguirem esse caminho artístico".

Para que as produções femininas tenham mais espaço na imprensa e mídia especializada, é preciso superar barreiras que, novamente, esbarram nos padrões estabelecidos por um mercado dominado pelo masculino, nos quadrinhos e na comunicação. Fernanda Nia aponta os caminhos para que isso aconteça: "falta trabalharmos o preconceito de que o material feminino ou e temática feminina é inferior e falta, e [...] mais espaço para mulheres no topo da cadeia produtiva e de comunicação de quadrinhos, não só na produção”.

Cátia Ana acredita que "a história deveria ser lida independente do gênero do autor", mas acaba percebendo que, por ser mulher, "já existe uma resistência antes mesmo da pessoa ver o que você produziu". Ela aposta na mídia especializada online como sugestão para ampliar a visibilidade de produções femininas: "a divulgação em espaços digitais especializados dá um retorno mais eficiente que o impresso, pois o primeiro já atinge o público que lê quadrinhos mesmo". Ou seja, a internet oferece ferramentas para que não leitores se interessem por quadrinhos.

Em relação à identificação e análise dos temas das webcomics produzidas pelas autoras da amostra, encontramos os seguintes padrões, agrupados por ordem de frequência: amizade; auto estima; amigo imaginário; vida adulta - trabalho e estudos; sexo; gênero e morte.

Os temas abordados nas webcomics publicadas por artistas brasileiras se desprendem em certa medida aos padrões encontrados nas HQs femininas impressas, em que pesam as escolhas editoriais. Para fins comparativos levantamos os títulos de mulheres publicados por editoras independentes do Brasil, que focam em trabalhos autorais e graphic novels. Dos 357 títulos, 73 são de mulheres ou parcerias. Desses 73, 39 são não-ficcionais, dentre eles, 26 são obras autobiográficas. 
Nas webcomics selecionadas nesta pesquisa, apenas uma é declaradamente autobiográfica entre as oito selecionadas; as outras são HQs de ficção. Se as escolhas editoriais privilegiam a narrativa do privado, na internet, isso não parece ser regra, já que a maioria das webcomics são ficcionais, trazem elementos fantásticos e personagens com poderes.

A internet tem sido uma ferramenta de auto-publicação entre autoras iniciantes e experientes, assim como um espaço de negociação, em que a produção feminina, muitas vezes invisível no mercado editorial, pode ser socializada e chegar a leitores ávidos por conteúdos mais diversos. Esse movimento de formação de leitores, que consomem HQs on-line e em feiras de publicações independentes, pode pressionar o mercado de quadrinhos a se atentar para questões de igualdade de gênero, raça, entre outras reivindicações de minorias.

O mundo das histórias em quadrinhos sempre contou com mulheres talentosas, desde os primórdios das publicações na imprensa. Trazer a produção feminina à luz significa reconhecer o protagonismo das mulheres enquanto criadoras e enriquecer o debate público com outras narrativas e olhares sobre a realidade, outras formas de abordar (e, sobretudo, questionar) o que é ser mulher. 


\section{REFERÊNCIAS}

ALVES, Zélia Maria Mendes Biasoli; SILVA, Maria Helena G. F. Dias da. Análise qualitativa de dados de entrevista: uma proposta. Paidéia. FFCLRP. USP-Ribeirão Preto, 2, Fev/Jul, 1992.

ABRECHT, Kristi Lyinn. Illustrating Identity: Feminist Resistance in Webcomics. Thesis Presented to the Faculty of San Diego State University. 2012.

BARCELLOS, Janice Primo. O feminino nas histórias em quadrinhos. Parte I: A mulher pelos olhos dos homens. Agaque. v. 2, n.4, 2000. Disponível em <http://www.eca.usp.br/agaque/agaque/ano2/numero4/artigosn4_1v2.htm >. Acesso em: 16 fev. 2016.

BARDIN, Laurence. Análise de conteúdo. Lisboa: 70, 1988.

BECHDEL, A. Fun home: uma tragicomédia em família. São Paulo: Conrad, 2007.

BOFF, Ediliane de Oliveira. De Maria a Madalena: representações femininas nas histórias em quadrinhos. Tese (Doutorado em Comunicações e Artes) Universidade de São Paulo, São Paulo. 2014.

BUTLER, Judith. Gender Trouble. Gender Trouble: Feminism and the Subversion of Identity. New York: Routledge, 1990.

CAPURRO, Rafael. Epistemologia e Ciência da Informação. In: V Encontro Nacional de Pesquisa em Ciência da Informação, Belo Horizonte (Brasil) 10 de novembro de 2003. Tradução de Ana Maria Rezende Cabral, Eduardo Wense Dias, Isis Paim, Ligia Maria Moreira Dumont, Marta Pinheiro Aun e Mônica Erichsen Nassif Borges. Disponível em: < http://www.capurro.de/enancib_p.htm >. Acesso em:15 jul. 2018

CARVALHO, Francismar Alex Lopes de. O conceito de representações coletivas segundo Roger Chartier. Diálogos, DHI/PPH/UEM, v. 9, n. 1, p. 143-165, 2005.

CASTELLS, Manuel. Internet e sociedade em rede. In: MORAES, Dênis de (org.). Por uma outra comunicação - Mídia, mundialização cultura e poder. Rio de Janeiro: Record, 2003.

CHENAULT, Wesley. Working the Margins: Women in the Comic Book Industry. Thesis Submitted in Partial Fulfillment of Requirements for the Degree of Master of Arts in the College of Arts and Sciences Georgia State University, 2007.

CHIZZOTTI, Antonio. Pesquisa qualitativa em ciências humanas e sociais. Petrópolis: Vozes, 2010.

CHUTE, Hillary L. Graphic Women: Life Narrative and Contemporary Comics. New York: Columbia University Press, 2010.

CRIPPA, Giulia. Público e privado em quadrinhos de autoria feminina: entre tradição e inovação. In Anais $4^{a}$ Jornadas Internacionais de Histórias em Quadarinhos - SP/SP - 22 a 25 Ago 2017.

DAVALLON, Jean. A mediação: a comunicação em processo? Tradução: Maria Rosário Saraiva. Paris, França: Médiatons \& Médiateurs, 2003. 
FOUCAULT, Michel. Microfísica do poder. Edições Graal, 8ª ed. 1979.

. História da sexualidade II: o uso dos prazeres. Rio de Janeiro: Graal, 1985.

A ordem do discurso: aula inaugural no Collège de France, pronunciada em 2 de dezembro de 1970. São Paulo: Loyola, 2009.

FRANCO, Edgar Silveira. Histórias em quadrinhos na internet: linguagem híbrida em gestação. In Anais INTERCOM Sociedade Brasileira de Estudos Interdisciplinares da Comunicação XXVI Congresso Brasileiro de Ciências da Comunicação - BH/MG - 2 a 6 Set 2003.

FROHMANN, B. O caráter social, material e público da informação. In: FUJITA, M.S.L.; MARTELETO, R.M.; LARA, M.L.G. (org.). A dimensão epistemológica da Ciência da Informação e suas interfaces técnicas, políticas e institucionais nos processos de produção, acesso e disseminação da informação. São Paulo: Cultura Acadêmica/Marília: FUNDEPE, 2008. p.13-34.

GIL, Antonio Carlos. Métodos e técnicas de pesquisa social. 4.ed., São Paulo: Atlas, 1994.

GONÇALO JÚNIOR. A Guerra dos Gibis: formação do mercado editorial brasileiro e a censura nos quadrinhos. 1933-64. São Paulo: Companhia das Letras, 2004.

GONZÁLEZ DE GOMÉZ, Maria Nélida. Metodologia de pesquisa no campo da Ciência da Informação. DataGramaZero - Revista de Ciência da Informação. v.1. n.6. dez-2000.

LIMA, Quesia dos Santos. Blogueiras feministas e o discurso de divulgação do feminismo no ciberespaço. In: Seminário de estudos em análise do discurso, 6., 2013, Rio Grande do Sul. Estudos em Análise do Discurso. Rio Grande do Sul: Instituto de Letras, 2013. Disponível em <http://www.ufrgs.br/analisedodiscurso/anaisdosead/6SEAD/SIMPOSIOS/BlogueirasFeminis tasEODiscurso.pdf >. Acesso em: 23 mai. 2016.

LUYTEN, Sônia. M. B. A mulher e a História em Quadrinhos: Sua produção e Retratação no Ocidente e no Oriente. In: Anais do VI Colóquio Internacional da Escola Latino Americana de Comunicação, São Paulo, 2002. Disponível em: Acesso em: outubro, 2016.

HALL, Stuart. A centralidade da cultura: notas sobre as revoluções culturais do nosso tempo. Educação \& Realidade, Porto Alegre, v. 22, n², p. 15-46, jul./dez. 1997.

LUND, N.W. Document theory. Annual Review of Information Science and Technology, v.43, n.1, p.1-55, 2009. Disponível em:

$<$ http://onlinelibrary.wiley.com/doi/10.1002/aris.2009.1440430116/fullgonzales de gomes

2009.> Acesso em 23 de maio de 2016.

JENKINS, Henri. Cultura da Convergência São Paulo: Aleph, 2008.

KRENING, Thiago da Silva; SILVA, Tânia Luisa Koltermann; SILVA, Régio Pierre da. Histórias em quadrinhos digitais: linguagem e convergência digital. Revista $9^{a}$ Arte. São Paulo, vol. 4, n. 2, $2^{\circ}$ semestre/2015.

MACEDO, A. G. Mulheres, arte e poder: uma narrativa de contrapoder? Margens e Confluências, Um Olhar Contemporâneo sobre as Artes. ESAP (Escola Superior Artística do Porto - Guimarães), em dezembro de 2006.

MARTELETO, Regina Maria. Redes sociais, mediação e apropriação de informações: situando campos, objetos e conceitos na pesquisa em Ciência da Informação. Pesq. bras. ci. inf., Brasília, v.3, n.1, p.27-46, jan./dez. 2010. 
McCLOUD, Scott. Reinventando os quadrinhos. São Paulo: M. Books, 2006.

NEVES, André Roberto Custódio; CHRISTINO, Daniel e RAMOS, Rubem Borges Teixeira. Arte sequencial e cultura da convergência - a conexão entre as histórias em quadrinhos e as novas tecnologias. Revista $9^{a}$ Arte. São Paulo, vol. 3, n. 1, 17-28, 1o. semestre/2014.

NOGUEIRA, Natania Aparecida da Silva. Gibiteca: ensino, criatividade e integração escolar. 2007.

. As representações femininas nas histórias em quadrinhos norte-americanas: June Tarpé Mills e sua Miss Fury (1941 - 1952). Dissertação Mestrado em História da Universidade Salgado de Oliveira, Rio de Janeiro, 2015.

OLIVEIRA, Maria Jaciara de Azeredo. As histórias em quadrinhos como fonte de informação: uma leitura de Fábulas no âmbito da Ciência da Informação. Dissertação de Mestrado em Ciência da Informação da Universidade Federal Fluminense. Niterói, RJ, 2014.

PLAZA, Julio. Arte e Interatividade: autor-obra-percepção. Revista do Departamento de Artes Plásticas ECA-USP, 1990. Disponível em <

http://www.cap.eca.usp.br/ars2/arteeinteratividade.pdf >. Acesso em 16 nov. 2016.

PAOLA, Power. Vírus Tropical; Trad. Nicolás Llano Linares e Marcela Vieira. 1 ed. São Paulo: Nemo, 2015.

RAMOS, Paulo. Histórias em quadrinhos: gênero ou hipergênero? Estudos Linguísticos, São Paulo, v. 3, n. 38, p. 355-367, set.-dez. 2009.

ROBBINS, Trina. A century of women cartoonists. Kitchen Sink Press, Inc. U.S.A. 1993.

. Wimmen's Studies. In: DANKY, James e KITCHEN Denis. Underground Classics: The Transformation of Comics into Comix. Abrams Comicarts Estados Unidos, 2009, p. 31-33.

SÁ, Christiane Corrêa de, VERGUEIRO, Waldomiro. As histórias em quadrinhos e seus suportes: do papel ao ambiente virtual. Revista $9^{a}$ Arte. São Paulo, vol. 4, n. 2, $2^{\circ}$ semestre/2015.

SANTOS, Roberto Elísio dos; SANTOS NETO, Elydio dos. Narrativas gráficas como expressões do ser humano. Revista Trama Interdisciplinar. v.1, n.2, 2011. Disponível em: < http://editorarevistas.mackenzie.br/index.php/tint/article/view/3113/2613 >. Acesso em 16 nov. 2016.

SATRAPI, M. Persépolis. São Paulo: Cia. Das Letras, 2007.

UGARTE, David de. O poder das redes: manual ilustrado para pessoas, organizações $e$ empresas, chamadas a praticar o ciberativismo. Porto Alegre: EDIPUCRS, 2008. Disponível em: < https://ciberconflitos.files.wordpress.com/2014/10/ugarte-david-2007-opoder-dasredes-em-portuguc3aas.pdf > Acesso em: 5 de agosto de 2016.

VERGUERO, Waldomiro; BARI, Valéria Aparecida. Perfil da leitora brasileira de quadrinhos: uma pesquisa participativa. Anais do XXV Congresso Anual em Ciência da Comunicação, Salvador/BA, 1 a 5 Set 2002.

. Histórias em quadrinhos e serviços de informação: um relacionamento em fase de definição. DataGramaZero - Revista de Ciência da Informação. v.6 n.2. abr/2005. 


\section{Hiperlinks consultados}

ATHAYDE, Laura. Mulheres que fazem quadrinhos e o boicote a Angoulême. Disponível em: < http://minasnerds.com.br/2016/01/07/mulheres-que-fazem-quadrinhos-eo-boicote-aangouleme/ >. Acesso em: 15 de julho de 2016.

BEAR. Sobre. Online. c2013. Disponível em<http://bear-pt.tumblr.com/>. Acesso em 15 julho de 2018.

BETE VIVE. About. Online. c2014. Disponível em 〈http://betevive.tumblr.com/〉. Acesso em 15 julho de 2018.

BOITEMPO._Homepage. Online. c2017. Disponível em $\langle$ https://www.boitempoeditorial.com.br/products/vitrine/barricada $>$. Acesso em 21 de abril de 2018 .

CASTILHO, Inês. No escurinho do cinema, a desigualdade perpetuada. 2016. Disponível em: < http://outraspalavras.net/blog/tag/teste-de-bechdel/ >. Acesso em 15 de março de 2017.

COMO EU REALMENTE... Homepage. Online. c2016. Disponível em $<$ http://www.comoeurealmente.com/>. Acesso em 15 julho de 2018.

DIÁRIO DE VIRGÍNIA O. Homepage. Online. [S/d]. Disponível em $<$ http://www.odiariodevirginia.com/>. Acesso em 15 julho de 2018.

EDITORA MINO. Homepage. Online. c2018._Disponível em $<$ http://www.editoramino.com/>. Acesso em21 de abril de 2018.

FRADE, Renan Martins. Afinal, como funciona o mercado de gibis nos EUA?. 2015.

Disponível em: < http://judao.com.br/afinal-como-funciona-o-mercado-de-gibis-noseua/ > . Acesso em: 21/03/2016.

FONSECA, Mariamma. As tiras de Pagu. 2012. Disponível em: < http://ladyscomics.com.br/as-tiras-de-pagu >. Acesso em: 4/04/2017.

GAROTA SIRIRICA. Homepage. Online. c2013. Disponível em <http://www.garotasiririca.com/ >. Acesso em 15 julho de 2018.

GLOBO, Editora. História. 2010. Disponível em: < http://editoraglobo.globo.com/historia.htm >. Acesso em? 13 de março de 2017.

GRUPO AUTÊNTICA. Nemo._Online. [S.d]. Disponível em <https://grupoautentica.com.br/nemo>. Acesso em21 de abril de 2018.

GRUPO CIA DAS LETRAS. Quadrinhos na Cia. Online.[S.d]. Disponível em <https://www.companhiadasletras.com.br/titulos.php?selo=Quadrinhos\%20na\%20Cia>. Acesso em21 de abril de 2018.

HQMIX. Conheça os indicados do troféu HQMIX 2105. Online. [S.d]. Disponível em < http://hqmix.com.br/blog/noticias/conheca-os-indicados-ao-trofeu-hqmix-2015/> Acesso em: 15 julho de 2018.

LADYS COMICS. Home. Online. [S/d]. Disponível em <http://ladyscomics.com.br/>. Acesso em 15 julho de 2018. 
LIZZIE BORDELLO E AS PIRATAS DO ESPAÇO. Homepage. Online. [S/d]. Disponível em <http://www.lizziebordello.com/ Acesso em 10 janeiro de 2016.

MANUAL DE SOBREVIVÊNCIA À VIDA ADULTA. Homepage. Online. [S/d]. Disponível em <https://medium.com/@brenddacostalima/manual-de-sobreviv\%C3\%AAncia\%C3\%A0-vida-adulta-d0e0e5f9d24b >. Acesso em 15 julho de 2018.

PÉDAUQUE, R. T. Document: Form, sign and medium, as reformulated for electronic documents. 2003. Disponível em: 〈 https://archivesic.ccsd.cnrs.fr/sic 00000594/document >. Acesso em 20 de julho de 2017.

RIBEIRO, Djamila. As diversas ondas do feminismo acadêmico. 2014. Disponível em: < https://www.cartacapital.com.br/blogs/escritorio-feminista/feminismo-academico9622.html >. Acesso em: 13 de março de 2017.

SOCIAL COMICS. Homepage. Online._c2016. Disponível em <https://www.socialcomics.com.br/>. Acesso em 15 julho de 2018.

VENETA. Homepage. Online. [S.d]. Disponível em <http://veneta.com.br/>. Acesso em21 de abril de 2018.

VIANA. G. Lizzie Bordello e as Piratas do Espaço. Online. [S/d \}. Disponível em <https://www.socialcomics.com.br/lizzie-bordello-e-as-piratas-do-espaco/1 >. Acesso em 15 julho de 2018.

ZINE XXX. Grupo fechado na Plataforma Facebook. Online. [S/d]. Disponível em <https://www.facebook.com/groups/412768682173074/>. Acesso em 15 julho de 2018. 


\section{APÊNDICE A - ENTREVISTAS}

\section{Modelo de entrevista}

Entrevista: Mulheres quadrinistas que fazem webcomics

Entrevistadora: Carolina Ito Messias

Dissertação de mestrado: Um panorama da produção feminina de quadrinhos publicados na internet no Brasil

Programa de Pós-Graduação em Ciência da Informação da Universidade de São Paulo (USP)

Orientadora: Giulia Crippa

Nome da Entrevistada:

Cidade onde mora:

Idade:

E-mail:

1. Há quanto tempo publica sua webcomic?

2. Como surgiu a ideia?

3. Qual a plataforma em que publica os quadrinhos (wordpress, blogspot, etc)? Ela é paga?

4. Qual frequência de atualização?

5. Sua HQ foi pensada para publicação online desde o início? Conte como foi esse processo de escolha e por que optou pelo digital.

6. A webcomic é publicada até hoje? Se não, por que não deu continuidade? (mencione até qual mês e ano foi publicada)

7. Possui fanpage nas redes sociais? Indique links, por favor.

8. Escreva uma pequena sinopse da história.

9. Quais recursos utiliza na produção (ilustração artesanal, digital, usa tablet ou mesa...)?

10. A sua webcomic possui versão impressa?

11. Já trabalhou com editora? Qual? (Indique se a editora publicou sua webcomic ou outra história)

12. Vive só do que ganha com a produção de quadrinhos ou possui outra profissão/ocupação? Qual?

13. Você acha que os quadrinhos digitais têm a mesma visibilidade e reconhecimento que os quadrinhos impressos?

14. Como as pessoas ficam sabendo da sua webcomic, em geral? Como elas chegam até o 
endereço do blog ou site?

15. Possui outras HQs impressas sem ser dessa webcomic? Quais?

16. Já foi indicada ou recebeu algum prêmio na área de quadrinhos?

17. Frequenta feiras e eventos sobre quadrinhos como expositora? Cite alguns exemplos das feiras que mais são importantes para divulgar seu trabalho.

18. Com que idade começou a ler quadrinhos? Quais?

19. Quais autores (as) mais a inspiram?

20. Quando começou a ler quadrinhos feitos por mulheres? Quais autoras?

21. Os números de mulheres indicadas a prêmios de quadrinhos ainda são baixos, em relação à presença masculina. Na sua opinião, por que isso acontece?

22. Você enxerga diferenças no modo como as personagens femininas são representadas, considerando as que são criadas por homens e mulheres? Quais?

23. Hoje se discute muito a questão da representatividade e reconhecimento da produção feminina de quadrinhos. Na sua opinião, o que garante que um trabalho seja reconhecido? De onde vem a visibilidade que as autoras reivindicam?

24. Qual a importância do seu trabalho ser citado em blogs, sites (jornalísticos), revistas especializadas e outras publicações relacionadas ao universo dos quadrinhos? Qual tipo de "imprensa" ajuda mais na divulgação?

25. O que falta para que as quadrinistas tenham a mesma representatividade e reconhecimento que os homens no meio dos quadrinhos?

26. Como as mulheres que publicam quadrinhos na internet podem melhorar a visibilidade de suas publicações? Que dicas você daria? 


\section{Entrevista 1}

Nome da entrevistada: Brendda Costa Lima.

Webcomic: Manual de sobrevivência à vida adulta.

Nome que assina as artes: Brendda

Cidade onde mora: Fortaleza - CE.

Idade: 24

E-mail: brenddaclima@gmail.com

\section{Há quanto tempo publica sua webcomic?}

Eu tento publicar coisas sobre a minha vida em formato web desde janeiro do ano passado.

\section{Como surgiu a ideia?}

A ideia surgiu da vontade de falar sobre o processo de crescer, ser mulher, morar só e ter ansiedade.

3. Qual a plataforma em que publica os quadrinhos (wordpress, blogspot, etc)? Ela é paga?

Publiquei o primeiro capítulo no Médium. Gostei do resultado, transformei em quadrinho, e recentemente eu passei a postar coisas no instagram

4. Qual frequência de atualização?

A atualização não é tão frequente quanto eu queria. Eu fico muito ansiosa por trabalhar e não ter mais tempo pra desenhar então eu passei um bom tempo travada. Hoje em dia eu tento encarar desenhar esse quadrinho como uma forma de expurgar sentimentos ruins e acabo postando só quando tenho uma página toda coloridinha ou quando tenho uma sequência de três quadros pra postar no Instagram.

5. Sua HQ foi pensada para publicação online desde o início? Conte como foi esse processo de escolha e por que optou pelo digital.

Não. Eu queria só experimentar quadrinizar me usando como personagem principal. Quando eu percebi que muitas outras mulheres também tinham ansiedade e inseguranças com a transição pra fase adulta, eu decidi dar continuidade. Em janeiro de 2016 eu publiquei as primeiras páginas online. Em setembro ele se tornou físico e agora no segundo semestre de 2017 ele voltou a ser online.

6. A webcomic é publicada até hoje? Se não, por que não deu continuidade? (mencione até qual mês e ano foi publicada)

Eu tenho um ritmo mais lento agora, por conta do trabalho. Infelizmente eu não consegui me manter trabalhando só com quadrinhos e pagar as contas :) 
7. Possui fanpage nas redes sociais? Indique links, por favor.

vanillatre.tumblr.com no Tumblr

@ drawbrendda no Instagram

E vanilla tree aqui no Facebook

8. Escreva uma pequena sinopse da história.

O manual de sobrevivência a vida adulta fala sobre ser mulher e ter ansiedade. Crescer, ter chefes ruins, chegar ao fim do mês sem grana é algo tão comum pra personagem quanto os gatinhos fantasmas que falam com ela.

(eu não sei escrever sinopses ahuahsua)

9. Quais recursos utiliza na produção (ilustração artesanal, digital, usa tablet ou mesa...)?

Meu processo, atualmente, é todo digital, apesar de emular texturas de aquarela. Meus melhores amigos são a mesinha digital e o Photoshop

10. A sua webcomic possui versão impressa?

Sim. Custa 8 reais e você pode encontrar a venda com a Netuno Press.

11. Já trabalhou com editora? Qual? (Indique se a editora publicou sua webcomic ou outra história)

Não

12. Vive só do que ganha com a produção de quadrinhos ou possui outra profissão/ocupação? Qual?

Não. Eu trabalho como designer gráfica numa agência de uma franquia de produtos pra sobrancelhas e cosméticos.

13. Você acha que os quadrinhos digitais têm a mesma visibilidade e reconhecimento que os quadrinhos impressos?

Eu acho que quadrinhos digitais tem mais reconhecimento entre o público do que os impressos. É muito mais fácil nessa era das redes sociais a galera ver o trabalho de um artista no Facebook ou no Instagram. Nosso país é gigante e eu ainda me impressiono com o fato de ter gente no RS que lê minhas coisas.

14. Como as pessoas ficam sabendo da sua webcomic, em geral? Como elas chegam até o endereço do blog ou site?

14. Eu não sei auaahuays acho que muitas gente marca os amiguinhos nas postagens e isso gera a interação.

15. Possui outras HQs impressas sem ser dessa webcomic? Quais?

15.Sim. meu primeiro quadrinho - Silêncio - foi impresso. Também colori Mayara e Annabelle 3 e Haole 3 


\section{Já foi indicada ou recebeu algum prêmio na área de quadrinhos?}

16. Fui indicada ao HQ Mix do ano passado pelas cores de Mayara e Annabelle, mas não ganhei :3

17. Frequenta feiras e eventos sobre quadrinhos como expositora? Cite alguns exemplos das feiras que mais são importantes para divulgar seu trabalho.

Sim. Tento ir ao máximo de eventos em Fortaleza. Junto com a Netuno Press - o coletivo que eu faço parte - frequentamos eventos em praças, o mercado de quadrinhos, o sana que é um evento voltado pra cultura asiática, mas com abertura pra produtores locais.

Também fui a Comic com experience - tour nordeste

E ao fiq de 2015

18. Com que idade começou a ler quadrinhos? Quais?

Nos jornais do meu estado (Ceará) circulavam tirinhas do Gabiras, Denilson Albano e Mino (um senhorzinho de 80 e tantos anos que tem um trabalho muito consistente) e eu fazia coleção desse material quando eu tinha uma média de 9/10 anos. A Turma da Mônica também era encartada num deles, aos Domingos, então eu tive acesso a esse material ainda novinha.

\section{Quais autores (as) mais a inspiram?}

Mas eu acho que só virei leitora assídua após descobrir Sandman, Umbrella Academy, Batgirl... Algum tempo depois eu descobri as autoras de quadrinhos (junto com o feminismo) e isso mudou a forma como eu lia, como percebia meu trabalho com ilustração.

Rebeca Sugar, NAtasha Allegri, Babs Tarr, Fran Nerd, Noelle Stevenson, Leslie Hung, Mariko e Jillian Tamaki, Sirlanney, Lovelove6, Barbara Malagoli, Renata Nolasco, Dharylia, Cris Peter, Lu Cafaggi, Luiza ( do IlustraLu), Dhiow, Débora Santos... Eu poderia passar o dia inteiro falando delas 
20. Quando começou a ler quadrinhos feitos por mulheres? Quais autoras?

21. Os números de mulheres indicadas a prêmios de quadrinhos ainda são baixos, em relação à presença masculina. Na sua opinião, por que isso acontece?

22. Você enxerga diferenças no modo como as personagens femininas são representadas, considerando as que são criadas por homens e mulheres? Quais?

23. Hoje se discute muito a questão da representatividade e reconhecimento da produção feminina de quadrinhos. Na sua opinião, o que garante que um trabalho seja reconhecido? De onde vem a visibilidade que as autoras reivindicam?

24. Qual a importância do seu trabalho ser citado em blogs, sites (jornalísticos), revistas especializadas e outras publicações relacionadas ao universo dos quadrinhos? Qual tipo de "imprensa" ajuda mais na divulgação?

25. O que falta para que as quadrinistas tenham a mesma representatividade e reconhecimento que os homens no meio dos quadrinhos?

26. Como as mulheres que publicam quadrinhos na internet podem melhorar a visibilidade de suas publicações? Que dicas você daria? 


\section{Entrevista 2}

Nome da entrevistada: Cátia Ana Baldoino da Silva

Webcomic: O Diário de Virgínia, Quadrinhos Infinitos

Nome que assina as artes: Cátia Ana

Cidade onde mora: Goiânia-GO

Idade: 34

E-mail: santanarev@gmail.com

\section{Há quanto tempo publica sua webcomic?}

O Diário de Virgínia publiquei de 2010 a 2016. Quadrinhos Infinitos a partir de 2016

\section{Como surgiu a ideia?}

Queria continuar a desenhando depois da faculdade de Design Gráfico e também fazer um processo de criação terapêutica, dai comecei a produzir O Diário de Virgínia. Quando encerrei o projeto quis continuar a criar narrativas para a web, então criei $o$ Quadrinhos Infinitos.

3. Qual a plataforma em que publica os quadrinhos (wordpress, blogspot, etc)? Ela é paga?

Tanto O Diário quanto o QI público em servidor pago, com domínio registrado.

4. Qual frequência de atualização?

Atualmente não tenho publicado no QI pois comecei meu mestrado esse ano, não tive mais tempo para produzir.

5. Sua HQ foi pensada para publicação online desde o início? Conte como foi esse processo de escolha e por que optou pelo digital.

O Diário inicialmente não, mas logo passei a pensar no conteúdo exclusivamente digital. A escolha do digital foi porque senti necessidade de publicar e, como meu trabalho não estava maduro, me auto-publicar foi a melhor escolha.

6. A webcomic é publicada até hoje? Se não, por que não deu continuidade? (mencione até qual mês e ano foi publicada)

O Diário se encerrou em janeiro de 2016, decidi parar pois estava remoendo muitos problemas pessoais e isso já estava ficando cansativo emocionalmente.

7. Possui fanpage nas redes sociais? Indique links, por favor.

Tenho sim, mas quase não as atualizo.

8. Escreva uma pequena sinopse da história.

O Diário de Virgínia é uma história com traços autobiográficos onde a personagem Virgínia lida com seus medos e conflitos internos ao dialogar com eles transmutados em personagens. 
Quadrinhos Infinitos contém histórias curtas diversas, feitas especialmente para leitura online.

9. Quais recursos utiliza na produção (ilustração artesanal, digital, usa tablet ou mesa...)?

Utilizo de tudo um pouco (nanquim, lápis aquarelável, colorização digital ou manual), vai depender mais do tipo de arte que a história pede.

10. A sua webcomic possui versão impressa?

Duas histórias do Diário sairam em dois álbuns, editados pela Marca de Fantasia em 2014 e 2015

11. Já trabalhou com editora? Qual? (Indique se a editora publicou sua webcomic ou outra história)

Fiz três histórias curtas para a Zarabatana Books que saíram impressas na coletânea SPAM, publicada em 2015.

12. Vive só do que ganha com a produção de quadrinhos ou possui outra profissão/ocupação? Qual?

Sou programadora visual na Universidade Federal de Goiás, os quadrinhos são um projeto que encaminho à parte do meu emprego.

13. Você acha que os quadrinhos digitais têm a mesma visibilidade e reconhecimento que os quadrinhos impressos?

Não. Publicar na mídia impressa ainda parece contar mais.

14. Como as pessoas ficam sabendo da sua webcomic, em geral? Como elas chegam até o endereço do blog ou site?

A minha principal divulgação é através do Facebook e Twitter.

15. Possui outras HQs impressas sem ser dessa webcomic? Quais?

Tem as histórias pra SPAM e duas revistas independentes que publiquei junto com outros quadrinhistas do Centro-oeste: as QUICOS 1 e 2 e a Pequi com Quadrinhos.

16. Já foi indicada ou recebeu algum prêmio na área de quadrinhos?

Já fui indicada ao Hqmix duas vezes, por conta do Diário, mas nunca ganhei.

17. Frequenta feiras e eventos sobre quadrinhos como expositora? Cite alguns exemplos das feiras que mais são importantes para divulgar seu trabalho.

Sempre que posso vou. Participo dos eventos que ocorrem por aqui (GO!HQ e Gibirama) e estive no último FIQ lançando a Pequi com Quadrinhos.

18. Com que idade começou a ler quadrinhos? Quais?

Comecei a ler mesmo durante a faculdade, com uns 23 anos. 
19. Quais autores (as) mais a inspiram?

Tem muitos que admiro o trabalho, mas a minha inspiração vem de tantos lugares que no final não sei citar especificamente algum quadrinista.

20. Quando começou a ler quadrinhos feitos por mulheres? Quais autoras?

Assim que comecei a fazer contatos por conta do Diário. Conheci o trabalho de autoras muito boas, como a Lu Cafaggi, a Samanta Floor, a Renata Rinaldi, a Camila Torrano, Germana Viana.

21. Os números de mulheres indicadas a prêmios de quadrinhos ainda são baixos, em relação à presença masculina. Na sua opinião, por que isso acontece?

Acho que falta visibilidade pro nosso trabalho, porque tem muita mulher produzindo.

22. Você enxerga diferenças no modo como as personagens femininas são representadas, considerando as que são criadas por homens e mulheres? Quais?

Dependendo do estilo os caras estereotipam mais as personagens femininas, quase sempre apelando pra uma sexualidade que as vezes não tem nada a ver com a história.

23. Hoje se discute muito a questão da representatividade e reconhecimento da produção feminina de quadrinhos. Na sua opinião, o que garante que um trabalho seja reconhecido? De onde vem a visibilidade que as autoras reivindicam?

Acho que deveria vir do público leitor, uma história deveria ser lida independente do gênero do autor mas a gente acaba percebendo que por ser mulher já há uma resistência antes mesmo da pessoa ver o que você produziu.

24. Qual a importância do seu trabalho ser citado em blogs, sites (jornalísticos), revistas especializadas e outras publicações relacionadas ao universo dos quadrinhos? Qual tipo de "imprensa" ajuda mais na divulgação?

É extremamente importante. Acho que a divulgação em espaços digitais especializados dá um retorno mais eficiente que o impresso, pois o primeiro já atinge o público que lê quadrinhos mesmo.

25. O que falta para que as quadrinistas tenham a mesma representatividade e reconhecimento que os homens no meio dos quadrinhos?

Talvez isso passe por uma mudança na sociedade como um todo, que acaba afetando nossa área.

26. Como as mulheres que publicam quadrinhos na internet podem melhorar a visibilidade de suas publicações? Que dicas você daria?

Não sei se poderia dar alguma dica, me acho um pouco preguiçosa nessa parte. Talvez a dica seja essa: sem preguiça, divulgue seu trabalho! :) 


\section{Entrevista 3}

Nome da entrevistada: Talita Albuquerque Hayata

Webcomic: BETE VIVE

Nome que assina as artes: Lita Hayata

Cidade onde mora: São Paulo

Idade: 31

E-mail: lita@dekoboko.com.br

\section{Há quanto tempo publica sua webcomic?}

4 anos.

\section{Como surgiu a ideia?}

Viajando no reveillon e pensando sobre o calor, a primeira vez que fui ao Rio, sobre como minhas amigas e minha namorada pensam diferente o mundo. Na época eu trabalhava com outros artistas em um estúdio de jogos, eles eram também quadrinistas. Eles me incentivaram a tentar fazer uma história.

3. Qual a plataforma em que publica os quadrinhos (wordpress, blogspot, etc)? Ela é paga?

Tapastic e Tumblr. Ambas gratuitas.

4. Qual frequência de atualização?

Duas vezes ao mês, mas com grandes hiatos.

5. Sua HQ foi pensada para publicação online desde o início? Conte como foi esse processo de escolha e por que optou pelo digital.

Sim. A Bete começou como uma experiência de como fazer quadrinhos, aproveitei e já procurei um lugar pra publicar. Na época uma publicação coletiva online, a Truko, ia lançar o segundo número e estava procurando por artistas com algum material. Fiz as primeiras páginas com as especificações pedidas lá. Eu já estava acostumada a ler coisas na internet, já tinha uma tablet por trabalhar com ilustração - e a distribuição online é muito menos trabalhosa. Foi uma facilidade.

6. A webcomic é publicada até hoje? Se não, por que não deu continuidade? (mencione até qual mês e ano foi publicada)

Sim. Parei de criar novas tiras até que as publicadas semanalmente no Tapastic alcançassem as já publicadas no Tumblr, mas assim que essa "migração" acabar vão sair novas. 
7. Possui fanpage nas redes sociais? Indique links, por favor.

https://www.facebook.com/betevive/

http://betevive.tumblr.com/

https://tapas.io/series/BETEVIVE

8. Escreva uma pequena sinopse da história.

Bete é uma mulher adulta tentando se virar na vida, aos trancos e barrancos. Ela vive sozinha até o dia em que a Morte aparece pra morar com ela.

9. Quais recursos utiliza na produção (ilustração artesanal, digital, usa tablet ou mesa...)?

Caderno de anotações pra sketches, tablet.

10. A sua webcomic possui versão impressa?

A personagem tem uma história fechada, não publicada na web, chamada "BETE VIVE: Jonatan".

11. Já trabalhou com editora? Qual? (Indique se a editora publicou sua webcomic ou outra história)

Não.

12. Vive só do que ganha com a produção de quadrinhos ou possui outra profissão/ocupação? Qual?

Não, trabalho como ilustradora.

13. Você acha que os quadrinhos digitais têm a mesma visibilidade e reconhecimento que os quadrinhos impressos?

Visibilidade sim, reconhecimento não.

14. Como as pessoas ficam sabendo da sua webcomic, em geral? Como elas chegam até o endereço do blog ou site?

Indicação de amigos, ou alguém que me conhece de outras áreas vê que estou publicando quando alardeio no twitter/fb.

15. Possui outras HQs impressas sem ser dessa webcomic? Quais?

Sim. "Melaço".

https://tapas.io/series/melaco

16. Já foi indicada ou recebeu algum prêmio na área de quadrinhos?

Indicada a novo talento na $H Q$ Mix de 2015, acredito. 
17. Frequenta feiras e eventos sobre quadrinhos como expositora? Cite alguns exemplos das feiras que mais são importantes para divulgar seu trabalho.

Sim. FIQ, Lady's Comics e CCXP.

18. Com que idade começou a ler quadrinhos? Quais?

Uns 5, só olhando figuras. Turma da Mônica.

19. Quais autores (as) mais a inspiram?

A Aline Lemos, Lovelove6, Julia Bax, Eleanor Davis, Rumiko Takahashi, Emily Carroll, Jillian Tamaki, Sam Bosma.

20. Quando começou a ler quadrinhos feitos por mulheres? Quais autoras?

Talvez 12, com autoras de manga. CLAMP (Rayearth, Sakura Card Captors), Naoko Takeushi (Sailor Moon), Rumiko Takahashi (Ranma 1/2).

21. Os números de mulheres indicadas a prêmios de quadrinhos ainda são baixos, em relação à presença masculina. Na sua opinião, por que isso acontece?

Acredito que porque, primeiramente, o número de publicações produzidas por homens é maior. Talvez por conta do estímulo que eles dão uns aos outros ou da cara de pau de ter um trabalho zoado e publicar mesmo assim. $O$ volume é maior. Depois as mulheres enfrentam uma crítica muito mais pesada até nos temas e no tipo de linguagem gráfica que escolhem - quando são coisas cotidianas, conflitos internos, romances etc, já recebem um "desconto" no sentido de que podem até ser ótimos, mas são ótimos em um gênero "menor". Quando mulheres vão para temas mais masculinos tem um frissom, uma expectativa, as pessoas lêem com muito mais peso. Tudo isso fora um cenário onde a maior parte dos críticos são homens, aí qualquer drama de corno manso bêbado ou herói com infância traumatizada tem vantagem, é "mais denso", talvez porque role uma empatia.

22. Você enxerga diferenças no modo como as personagens femininas são representadas, considerando as que são criadas por homens e mulheres? Quais?

Sim. Na maior parte, as mulheres criadas por mulheres são personagens, as mulheres criadas por homens são argumentos. Existem exceções, algumas das mulheres que gosto muito foram criadas por homens (a velha e a bruxa em "The Hanging Tower"), enquanto várias mulheres criadas por mulheres parecem mais panfletos. Mas em geral as mulheres escrevem pessoas (a Garota Siririca e suas amigas, as meninas do "This One Summer", as sailors, a mãe em "The Man Who Came Down The Attic", as atrizes de "BDSM") e os homens escrevem "uma mulher delicada" "uma mulher forte" etc. Personagens homens femininos que gosto foram *todos* criados por mulheres (pensando em "Yuri on Ice").

23. Hoje se discute muito a questão da representatividade e reconhecimento da produção feminina de quadrinhos. Na sua opinião, o que garante que um trabalho seja reconhecido? De onde vem a visibilidade que as autoras reivindicam?

Um trabalho é reconhecido se é visível, se é bom, se tem consistência. O custo disso é maior para mulheres do que para homens. Assim a exigência imediata é sempre que as mulheres superem a bostalhada toda que acontece diariamente, nos mais diversos niveis, e no fim tenham fôlego pra produzir um material legal. Com o material pronto tem 
também uma "reeducação" sobre o que é quadrinho bom, pra que não só as mulheres percebam a importância de assunto $x$, a qualidade do traço y. E também um esforço conjunto de inserção de mulheres em todos os lugares - mulheres em grupos de enfrentamento, grupos de apoio, grupos de produção. O pessoal que está produzindo uma hora esbarra no pessoal que fez pressão pra que um evento tivesse uma curadora mulher, com sorte essa tem menos preconceito com a produção das mulheres e indica várias -assim vai.

24. Qual a importância do seu trabalho ser citado em blogs, sites (jornalísticos), revistas especializadas e outras publicações relacionadas ao universo dos quadrinhos? Qual tipo de "imprensa" ajuda mais na divulgação?

Toda importância. Pouco dinheiroltempo rolando, acúmulo de funções (roteirizar, quadrinizar, desenhar, digitalizar, editar, publicar, divulgar, gerir, acessorar...) $e$ público leitor distante faz com que a divulgação seja uma parte bem secundária do trabalho.

Acho que tanto a imprensa maior, que tem mais alcance e mais leitores, quanto os reviews pequenos de blogs, vlogs, etc são importantes pra atingir o público que as suas próprias postagens não vão alcançar. Uma indicação num canal de cultura pop com muitos seguidores às vezes é o que faz a diferença pro público se expandir.

25. O que falta para que as quadrinistas tenham a mesma representatividade e reconhecimento que os homens no meio dos quadrinhos?

A produção e a qualidade estão aí e as mulheres sabem disso. Falta o reconhecimento em si, que é um problema da ignorância dos homens.

26. Como as mulheres que publicam quadrinhos na internet podem melhorar a visibilidade de suas publicações? Que dicas você daria?

Se o quadrinho não é a vida da autora (como no caso da Sirlanney), acho que a melhor coisa é organizar muito muito bem. Não deixar as publicações do quadrinho no meio de publicações pessoais, ter um plano de atualizações, ter o endereço de um site ou um impresso sempre à mão. Ir trabalhando consistentemente, insistentemente, e vocalizar isso com segurança. Procurar companhia, saber da história de outras mulheres quadrinistas e entrar em contato com elas. Garimpar críticas. Se divertir escrevendo e desenhando. 


\section{Entrevista 4}

Nome da entrevistada: Bianca Pinheiro

Webcomic: Bear (http://bear-pt.tumblr.com/)

Nome que assina as artes: Bianca Pinheiro

Cidade onde mora: Curitiba

Idade: 29 anos

E-mail: bcristaldi@gmail.com

1. Há quanto tempo publica sua webcomic?

Há quatro anos. Pouco mais de quatro anos.

2. Como surgiu a ideia?

Еu queria me forçar a fazer quadrinhos semanalmente e meu marido sugeriu que eu fizesse uma webcomic para atender a esta necessidade.

3. Qual a plataforma em que publica os quadrinhos (wordpress, blogspot, etc)? Ela é paga?

Publico pelo tumblr. Não é pago.

4. Qual frequência de atualização?

Uma página por semana.

5. Sua HQ foi pensada para publicação online desde o início? Conte como foi esse processo de escolha e por que optou pelo digital.

Foi pensada para ser online desde o começo, sim. A ideia era me manter motivada, então eu faria uma página por semana (uma que mais ou menos desse uma sensação de desfecho), e já receberia o feedback imediato dos leitores. Isso porque eu trabalhava mais de 8 h por dia em uma empresa e não conseguia chegar em casa e trabalhar numa HQ longa. Por isso a ideia da webcomic.

6. A webcomic é publicada até hoje? Se não, por que não deu continuidade? (mencione até qual mês e ano foi publicada)

Sim, ainda é publicada.

7. Possui fanpage nas redes sociais? Indique links, por favor.

Sim, possui página no facebook. https://www.facebook.com/bear.webcomicl

8. Escreva uma pequena sinopse da história.

A pequena Raven se perde de casa e, enquanto tenta encontrar o caminho de volta, acaba parando na caverna de um urso. O urso, apesar de rabugento, decide ajudar a menina a voltar para casa. E assim se inicia a jornada de Raven e Dimas (o urso). 
9. Quais recursos utiliza na produção (ilustração artesanal, digital, usa tablet ou mesa...)?

Faço todo o processo, com exceção do storyboard, de maneira digital. Uso, atualmente, uma Wacom Cintiq 13HD. No começo, usava uma Wacom Bamboo.

10. A sua webcomic possui versão impressa?

Sim.

11. Já trabalhou com editora? Qual? (Indique se a editora publicou sua webcomic ou outra história)

Sim. Editora Nemo (publica Bear), editora Panini e editora Mino.

12. Vive só do que ganha com a produção de quadrinhos ou possui outra profissão/ocupação? Qual?

Vivo basicamente de quadrinhos e de freelas de ilustração.

13. Você acha que os quadrinhos digitais têm a mesma visibilidade e reconhecimento que os quadrinhos impressos?

Não, não têm. Ser impresso valida o quadrinho. Ser só digital ainda parece amador.

14. Como as pessoas ficam sabendo da sua webcomic, em geral? Como elas chegam até o endereço do blog ou site?

No começo só amigos meus liam. Eu sempre divulgo nas minhas redes sociais e na própria fanpage de Bear. Meus amigos começaram a compartilhar e outras pessoas foram conhecendo e compartilhando. Assim se fez uma pequena rede de leitores.

15. Possui outras HQs impressas sem ser dessa webcomic? Quais?

Sim. "Dora" (2014, Independente - republicada em 2016 pela editora Mino), "Meu pai é um homem da montanha” (2015 - independente) e Mônica - Força (2016 - Panini)

Bear foi publicado até o terceiro volume pela editora nemo (de 2014 a 2016, um por ano).

16. Já foi indicada ou recebeu algum prêmio na área de quadrinhos?

Sim. Recebi o premio HQMix de Roteirista Revelação em 2015, fui indicada em 2016 a diversas categorias (mas não ganhei nenhuma) e também fui indicada agora em 2017 (ganhei na categoria publicação juvenil, mas o resultado ainda não saiu).

17. Frequenta feiras e eventos sobre quadrinhos como expositora? Cite alguns exemplos das feiras que mais são importantes para divulgar seu trabalho.

Sim, frequento. As que dão melhor retorno são a CCXP (São Paulo), a Gibicon (Curitiba) e o FIQ (Belo Horizonte).

18. Com que idade começou a ler quadrinhos? Quais?

Muito nova, nem lembro direito. Minha mãe lia Turma da Mônica para mim. 
19. Quais autores (as) mais a inspiram?

Anders Nilsen, Emily Carroll, Noelle Stevenson, Katsuhiro Otomo, Hitoshi Iwaaki, Akira Toriyama, Rumiko Takahashi, CLAMP, Hayao Miyazaki, Rebecca Sugar, Jason, Laerte e Rafael Coutinho.

20. Quando começou a ler quadrinhos feitos por mulheres? Quais autoras?

As primeiras que li foram as do grupo CLAMP (Sakura Card Captors e Guerreiras Mágicas de Rayearth, principalmente) e Rumiko Takahashi (Inuyasha).

21. Os números de mulheres indicadas a prêmios de quadrinhos ainda são baixos, em relação à presença masculina. Na sua opinião, por que isso acontece?

Eu não sei exatamente e nem posso afirmar com certeza. Mas imagino que tenha a ver com a diferença de quantidade de homens e de mulheres fazendo quadrinhos. Mas é uma matemática no campo das ideias. Não tenho informações concretas para afirmar nada. Mas eu chutaria que essa é a causa. A maior parte dos quadrinistas homens que conheço também nunca recebeu indicação a prêmio algum.

22. Você enxerga diferenças no modo como as personagens femininas são representadas, considerando as que são criadas por homens e mulheres? Quais?

De que tipo de quadrinhos estamos falando aqui? Pessoal fala bastante de como as mulheres são mal representadas em quadrinhos de heróis (e eu acredito, com base nas imagens que divulgam, hahaha), mas eu não leio quadrinhos de heróis, então não tenho esse contato. Nos quadrinhos que eu leio e que mais me influenciam (vendo pelos autores que mencionei na parte de inspiração), confesso não ver diferença.

23. Hoje se discute muito a questão da representatividade e reconhecimento da produção feminina de quadrinhos. Na sua opinião, o que garante que um trabalho seja reconhecido? De onde vem a visibilidade que as autoras reivindicam?

Posso estar muito enganada, mas acredito que o reconhecimento de uma trabalho ocorre quando ele consegue se encaixar em alguma categoria de coisas que fazem algum sucesso no momento. Veja Steven Universe, por exemplo, é um desenho do Cartoon Network, criado por uma mulher, protagonizado por um menino e três mulheres. $O$ sucesso deste desenho é estrondoso (muito maior do que Clarence, por exemplo, outro desenho do mesmo canal, criado por um homem e protagonizado por três meninos). Eu não acho que um seja melhor do que o outro. Gosto muito dos dois. Mas acredito que o sucesso de Steven Universe se dê por estar mais adequado ao que se espera de um desenho atualmente (super-poderes, bastante ação, e uma boa pitada de militância $L G B T$, que está ganhando cada vez mais palco e atenção).

24. Qual a importância do seu trabalho ser citado em blogs, sites (jornalísticos), revistas especializadas e outras publicações relacionadas ao universo dos quadrinhos? Qual tipo de "imprensa" ajuda mais na divulgação?

A minha pequena experiência no mundo dos quadrinhos me mostra que quem mais movimenta as coisas são os YouTubers de quadrinhos. Canais como Dois Quadrinhos e Pipoca \& Nanquim foram grandes responsáveis por muitas das minhas vendas (em especial as independentes). Mas as críticas (positivas) em blogs e sites servem muito também para mostrarmos aos leitores que tem gente lendo nosso quadrinho e se 
importando com eles o suficiente para falar a respeito. Então eu diria que essa divulgação é de extrema importância.

25. O que falta para que as quadrinistas tenham a mesma representatividade e reconhecimento que os homens no meio dos quadrinhos?

Novamente, do que exatamente estamos falando? Se o reconhecimento for em um mercado como o de super-heróis americanos, imagino que o caminho seja desenhar, escrever e colorir como se espera no mercado. Em matéria de quadrinho autoral, é difícil saber. É aquilo que eu disse, acho que o lance é acertar no que faz sucesso dentro do ambiente em que se publica (seja o fofo, aventuras, cotidiano, underground e por aí vai). Ou mesmo fazer como o próprio Mauricio de Sousa sugere: encontre um segmento não explorado do mercado, explore e tome conta.

26. Como as mulheres que publicam quadrinhos na internet podem melhorar a visibilidade de suas publicações? Que dicas você daria?

Se o foco for apenas a visibilidade e o (possível) dinheiro e fama que vêm com ela, mantenho o meu posicionamento da pergunta anterior: faça um cálculo minucioso do que faz sucesso e trabalhe em cima disso. Se, no entanto, o interesse for fazer o que você está afim de fazer, eu digo faça o que gosta com o que você tiver. Estude bastante para se aprimorar e vai fundo. Se tiver sorte, o que você gosta de fazer e o que o povo gosta de ler será a mesma coisa. 


\section{Entrevista 5}

Nome da entrevistada: Cristiane Duarte Peter

Webcomic: Quimera

Nome que assina as artes: Cris Peter

Cidade onde mora: Porto Alegre

Idade: 34 anos

E-mail: crispeterdigitalcolors@ gmail.com

\section{Há quanto tempo publica sua webcomic?}

Iniciei a produção no ano passado, 2016.

\section{Como surgiu a ideia?}

A idéia surgiu de uma demanda. Uma editora estava planejando um selo de quadrinhos a serem publicados na plataforma de streaming Social Comics e me convidou para criar algo com a temática sugerida: Super heroínas sob a perspectiva feminina.

3. Qual a plataforma em que publica os quadrinhos (wordpress, blogspot, etc)? Ela é paga?

Social Comics. É paga mensalmente, assim como a Netflix.

4. Qual frequência de atualização?

Não existe uma exigência nem uma frequência. Tentamos administrar espaços de tempo entre um trabalho particular ou outro.

5. Sua HQ foi pensada para publicação online desde o início? Conte como foi esse processo de escolha e por que optou pelo digital.

Sim, porém sempre ouve o interesse de posteriormente esses quadrinhos virem a serem impressos no momento em que os arcos se fechassem. Mesmo assim, na hora do desenvolvimento de roteiro, tive a preocupação de deixar um "gancho"no último quadro de cada página para dar ao leitor a curiosidade de saber o que acontece, já que na plataforma online as páginas são visualizadas individualmente. A opção pelo digital partiu pelo convite da própria Social Comics.

6. A webcomic é publicada até hoje? Se não, por que não deu continuidade? (mencione até qual mês e ano foi publicada)

Sim, com um grande atraso, mas ainda está sendo publicada. Como comentei anteriormente, produzimos essas páginas com a administração de tempo ocioso que temos entre outros trabalhos pagos, por isso a produção continua fica prejudicada, mas o projeto continua. 
7. Possui fanpage nas redes sociais? Indique links, por favor.

Tenho perfil no Instagram e página no Facebook, mas não relacionado a webcomic: @ diariodefreela e Cris Peter Digital Colors LTDA.

8. Escreva uma pequena sinopse da história.

Quimera fala da história de como Nicole (uma jovem humilde da cidade de Porto Alegre) e Anna (uma mulher recém separada de Bento Gonçalves que acaba de se mudar para a capital) se conheceram e de como suas histórias mudaram completamente quando suas vidas se interligaram através de um poder desconhecido que transforma elas em um ser poderoso apelidado de Quimera.

9. Quais recursos utiliza na produção (ilustração artesanal, digital, usa tablet ou mesa...)?

O trabalho é dividido. Eu faço o roteiro e as cores digitalmente com o software Photoshop. A Dika Araujo faz os desenhos de maneira artesanal usando papel, lápis e canetas técnicas.

10. A sua webcomic possui versão impressa?

Ainda não.

11. Já trabalhou com editora? Qual? (Indique se a editora publicou sua webcomic ou outra história)

Sim, já trabalhei com a Marsupial para a publicação de meu livro teórico O Uso das Cores.

12. Vive só do que ganha com a produção de quadrinhos ou possui outra profissão/ocupação? Qual?

Vivo de quadrinhos, mas não de produção própria. Meu trabalho principal é como colorista de histórias em quadrinhos e meus trabalhos são direcionados para editoras norte-americanas.

13. Você acha que os quadrinhos digitais têm a mesma visibilidade e reconhecimento que os quadrinhos impressos?

Acho que não, mas os dois possuem uma grande dificuldade de divulgação. O nicho dos quadrinhos é muito restrito e a divulgação é muito dificultada pelas constantes mudanças de algoritmo das plataformas digitais.

14. Como as pessoas ficam sabendo da sua webcomic, em geral? Como elas chegam até o endereço do blog ou site?

Minha plataforma de divulgação é facebook e instagram, meus seguidores me ajudam com uma divulgação boca a boca, mas mesmo assim o alcance é bem restriro, pois mesmo as pessoas que me seguem tem dificuldades de se manterem informadas de todas as novidades. 


\section{Possui outras HQs impressas sem ser dessa webcomic? Quais?}

Sim. Tenho uma série chamada Patas Sujas, e como colorista já trabalhei em Pétalas, Astronauta Magnetar, Singularidade e Assimetria (das Graphic MSP) e Escolhas.

16. Já foi indicada ou recebeu algum prêmio na área de quadrinhos?

Sim, já recebi, por meu trabalho de colorização no título Casanova uma indicação para o Eisner Awards e ganhei um HQMix pelo meu trabalho de cor em Astronauta Singularidade.

17. Frequenta feiras e eventos sobre quadrinhos como expositora? Cite alguns exemplos das feiras que mais são importantes para divulgar seu trabalho.

Sim, Comic Con Experience e o Festival Internacional de Quadrinhos são os eventos mais importantes.

18. Com que idade começou a ler quadrinhos? Quais?

Comecei a ler quadrinhos por volta dos meus 17 anos.

19. Quais autores (as) mais a inspiram?

Tenho muitas influências fora dos quadrinhos, principalmente em filmes. Mas na atualidade, os autores que mais me inspiram são Hayao Miyazaki e Brian K. Vaughan.

20. Quando começou a ler quadrinhos feitos por mulheres? Quais autoras?

Comecei a ler mais recentemente. Sempre acompanho a produção nacional pela internet: Laura Athayde, Sirlaney, Rebeca Prado, mas também acompanhei algumas coisas escritas pela Kelly Sue DeConnick e G. Willow Wilson. Porém ando trabalhando demais pra me manter sempre atualizada. Leitura é o que menos consigo fazer enquanto trabalho com quadrinhos.

21. Os números de mulheres indicadas a prêmios de quadrinhos ainda são baixos, em relação à presença masculina. Na sua opinião, por que isso acontece?

Acontece pois ainda somos minoria com destaque no mercado. Quanto mais produzirmos e impomos espaço, mais presença teremos em eventos e premiações, mais meninas verão que existe possibilidades pra elas aqui, e assim aumentamos o numero de profissionais qualificadas pra fazerem parte de premiações.

22. Você enxerga diferenças no modo como as personagens femininas são representadas, considerando as que são criadas por homens e mulheres? Quais?

Sim. Fico feliz em dizer que a erotização das mulheres pelos homens diminuiu, muito pouco, mas diminuiu. Mesmo assim, ainda percebo uma preocupação estética muito maior com as mulheres do que os homens. A necessidade de serem bonitas e sensuais ainda é muito grande para os artistas homens, já a representação masculina deles é muito mais heróica e forte. 
23. Hoje se discute muito a questão da representatividade e reconhecimento da produção feminina de quadrinhos. Na sua opinião, o que garante que um trabalho seja reconhecido? De onde vem a visibilidade que as autoras reivindicam?

Eu acredito que ainda precisamos de mais reconhecimento, visibilidade e inclusão nos circulos de negociação. Sim, eu vejo um problema de qualidade no trabalho de muitas meninas, não vou negar. E o problema da insegurança que temos acaba nos travando de continuar com a prática. Ainda temos essa trava social e vontade de nos encolhermos às dificuldades que o mercado nos dá. Isso vem da nossa educação, somos ensinadas a não nos impormos, e isso acaba prejudicando nossa qualidade artistica, pois muitas vezes não desafiamos criticas e não usamos elas como um obstáculo, e sim como uma razão para desistir. Existe sim, muito machismo e exclusão, mas para batermos de frente, também precisamos nos especializar mais como artistas constantemente. Hoje fico orgulhosa de conversar com amigos donos de escola de arte e saber que o numero de meninas nas turmas está aumentando absurdamente! O único cuidado que precisamos tomar é o de não nos tornarmos estudantes eternas, precisamos treinar nossa confiança para expor nossos trabalhos às criticas e conseguir aprender com elas, não nos proteger delas. Resistências existirão sempre, só não podemos nos encolher em frente a elas.

24. Qual a importância do seu trabalho ser citado em blogs, sites (jornalísticos), revistas especializadas e outras publicações relacionadas ao universo dos quadrinhos? Qual tipo de "imprensa" ajuda mais na divulgação?

Importantíssimo, pois quanto mais mulheres e meninas tiverem conhecimento da minha existência no mercado, mais elas verão a possibilidade de também seguirem esse caminho artistico. Qualquer imprensa é bem vinda, mas as digitais são as melhores, pois é onde o publico alvo dos quadrinhos está concentrado.

25. O que falta para que as quadrinistas tenham a mesma representatividade e reconhecimento que os homens no meio dos quadrinhos?

Produção constante. Mas isso já está acontecendo e os destaques já estão começando.

26. Como as mulheres que publicam quadrinhos na internet podem melhorar a visibilidade de suas publicações? Que dicas você daria?

Com as dificuldades que a propria ferramenta das plataformas anda apresentando, nem sei o que sugerir. Mas um planejamento de publicações constantes é necessário e a preocupação estética com os trabalhos mostrados também. 


\section{Entrevista 6}

Nome da entrevistada: Gabriela Teixeira Masson

Webcomic: Garota Siririca

Nome que assina as artes: Lovelove6

Cidade onde mora: Brasília

Idade: 27 anos

E-mail: contato@lovelove6.com

\section{Há quanto tempo publica sua webcomic?}

Comecei em 2013.

\section{Como surgiu a ideia?}

A partir das minhas experiências pessoais e da percepção de que, até onde eu conseguia procurar, não haviam quadrinhos sobre sexualidade, com uma pegada feminista, sendo feitos no Brasil.

3. Qual a plataforma em que publica os quadrinhos (wordpress, blogspot, etc)? Ela é paga?

Comecei publicando em plataforma blogger (site da revista Samba). Hoje minha principal plataforma é o site www.lovelove6.com cuja hospedagem eu contrato.

Além dele eu publico no Facebook e em outras redes sociais.

4. Qual frequência de atualização?

Durante o período de publicação da primeira série, publicava uma página toda sextafeira, por cerca de um ano e meio.

5. Sua HQ foi pensada para publicação online desde o início? Conte como foi esse processo de escolha e por que optou pelo digital.

Sim. Quando comecei não tinha conhecimento ou dinheiro para investir em impressos. Também precisava que a hq, ainda desconhecida, chegasse em muitas pessoas sem demora. Por isso decidi publicar online e gratuitamente.

6. A webcomic é publicada até hoje? Se não, por que não deu continuidade?

Acredito que ela tenha sido publicada regularmente na internet de junho de 2013 até abril de 2015.

O arco da história foi encerrado. Hoje eu estou trabalhando no roteiro para uma continuidade da série e num spin-off de uma das personagens. 
7. Possui fanpage nas redes sociais? Indique links, por favor.

www.instagram.com/odiozinho

www.facebook.com/lvlv666

www.lovelove6.com

8. Escreva uma pequena sinopse da história.

A Garota Siririca é uma mina viciada em masturbação e por causa dessa obsessão ela se mete com as suas amigas em situações engraçadas e constrangedoras.

9. Quais recursos utiliza na produção (ilustração artesanal, digital, usa tablet ou mesa...)?

Desenho com grafite, finalizo com nanquim, trato e colorizo digitalmente.

10. A sua webcomic possui versão impressa?

Sim.

11. Já trabalhou com editora? Qual? (Indique se a editora publicou sua webcomic ou outra história)

Não.

12. Vive só do que ganha com a produção de quadrinhos ou possui outra profissão/ocupação? Qual?

Eu faço jobs de freelancer de ilustração, quadrinhos, webdesigner; dou oficinas, cursos, palestras, produzo eventos de publicação independente.

13. Você acha que os quadrinhos digitais têm a mesma visibilidade e reconhecimento que os quadrinhos impressos?

Eles tem visibilidades e reconhecimentos diferentes, se melhores ou piores vai depender de qual é a ambição da autora.

14. Como as pessoas ficam sabendo da sua webcomic, em geral? Como elas chegam até o endereço do blog ou site?

Acredito que por indicação de pessoas que já leram a história antes.

15. Possui outras HQs impressas sem ser dessa webcomic? Quais?

Sim, tenho algumas zines, além de participações em revistas e antologias como o jornal Suplemento, Pimba, o livro Topografias.

16. Já foi indicada ou recebeu algum prêmio na área de quadrinhos?

Fui finalista em 2016 da categoria de quadrinhos eróticos no famigerado HQMIX, mas não ganhei. 
17. Frequenta feiras e eventos sobre quadrinhos como expositora? Cite alguns exemplos das feiras que mais são importantes para divulgar seu trabalho.

Sim. Feira Dente, Feira Plana, FIQ, Des. Gráfica, Bienal de Quadrinhos de Curitiba.

18. Com que idade começou a ler quadrinhos? Quais?

Ainda durante a alfabetização eu comecei a ler Turma da Mônica.

19. Quais autores (as) mais a inspiram?

Sophie Campbell, Jesse Moynihan, Shintaro Kago, Naoko Takeuchi, Laura Lannes, Puiupo, Lucas Gehre, são referências de quadrinistas constantes pra mim há um tempo.

20. Quando começou a ler quadrinhos feitos por mulheres? Quais autoras?

Com cerca de 09 anos comecei a ler mangás do grupo CLAMP.

21. Os números de mulheres indicadas a prêmios de quadrinhos ainda são baixos, em relação à presença masculina. Na sua opinião, por que isso acontece?

Porque há muito menos mulheres se publicando e sendo publicadas por editoras, em formato impresso, do que homens; e todos os prêmios brasileiros com categorias de histórias em quadrinhos privilegiam o formato impresso.

22. Você enxerga diferenças no modo como as personagens femininas são representadas, considerando as que são criadas por homens e mulheres? Quais?

Os homens em geral tem um imaginário hiperssexualizado e misógino em relação ao corpo das mulheres e isso se reflete na construção das visualidades, da narrativa e do desenho nos quadrinhos.

As mulheres tendem a representar personagens femininas com narrativas mais realistas $e$ complexas, justamente por muitas não se verem como o objeto sexual ou repugnante que muitos homens projetam. Mas não existe uma diferença essencial na maneira como homens e mulheres representam personagens femininas quando ambos compartilham o mesmo imaginário e ideologia heteronormativa.

23. Hoje se discute muito a questão da representatividade e reconhecimento da produção feminina de quadrinhos. Na sua opinião, o que garante que um trabalho seja reconhecido? De onde vem a visibilidade que as autoras reivindicam?

Nada garante que um trabalho vá ser amplamente reconhecido, apesar de que é possível comprar algum reconhecimento quando se tem grana pra investir em marketing. A visibilidade pode vir de muitos lugares diferentes. Atualmente acho que principalmente nós reivindicamos curadorias editoriais preocupadas em compensar o machismo histórico do mercado e em valorizar e icentivar os trabalhos de jovens autoras; e também ocupar os espaços de discussão e educação em eventos voltados às histórias em quadrinhos na mesma proporção que os homens ocupam. 
24. Qual a importância do seu trabalho ser citado em blogs, sites (jornalísticos), revistas especializadas e outras publicações relacionadas ao universo dos quadrinhos? Qual tipo de "imprensa" ajuda mais na divulgação?

É importante para me legitimar como autora, fazer o registro do meu trabalho $e$ compartilhar com o público as minhas reflexões sobre os quadrinhos que ele tem lido. Pessoalmente as melhores experiências com imprensa que tive foram entrevistas produzidas por feministas para sites jornalísticos ou sites de bobagem hypados. Então eu diria que a impressa feminista ajuda mais na divulgação.

25. O que falta para que as quadrinistas tenham a mesma representatividade e reconhecimento que os homens no meio dos quadrinhos?

Falta a gente superar as imensas distâncias geográficas entre nós e bolarmos projetos e oportunidades pra nós mesmas, largar mão da necessidade de ser reconhecida pelas entidades legitimadoras e machistas envolvidas no role, confiar em si mesma e no próprio trabalho, estudar, refletir e desenhar muito mais quadrinho pra compensar a história.

26. Como as mulheres que publicam quadrinhos na internet podem melhorar a visibilidade de suas publicações? Que dicas você daria?

Publicar com regularidade e disciplina em todas as redes sociais possíveis, desenhar e pensar em quadrinhos o tempo todo, pensar muito sobre o que faz uma boa história. 


\section{APÊNDICE B - DADOS DAS ENTREVISTAS}

Quadro 3 - Entrevistas

\begin{tabular}{|c|c|c|c|c|}
\hline Identificação da autora & $\begin{array}{l}\text { Bianca Pinheiro } \\
\text { (28 anos, Curitiba-PR) }\end{array}$ & $\begin{array}{l}\text { Amanda Reis } \\
\text { Assina: Bianka } \\
(23 \text { anos, Belo Horizonte } \\
\text { MG) }\end{array}$ & $\begin{array}{l}\text { Carolina Costa Rossetti } \\
\text { Assina: Carol Rosseti } \\
\text { (28 anos, Belo Horizonte MG) }\end{array}$ & $\begin{array}{l}\text { Rebeca Prado Santos Assina: } \\
\text { Rebeca Prado ( } 25 \text { anos, Brasília- } \\
\text { DF) }\end{array}$ \\
\hline Publicação online & Bear(bear-pt.tumblr.com) & $\begin{array}{l}\text { "Anna Bolenna - a } \\
\text { perturbada da corte" } \\
\text { Link: Anna bolenna.com }\end{array}$ & $\begin{array}{l}\text { "Cores" / "Vamos conversar?" } \\
\text { Link: www.carolrossetti.com.br }\end{array}$ & $\begin{array}{l}\text { "Navio Dragão" } \\
\text { Link: naviodragao.wordpress.com }\end{array}$ \\
\hline $\begin{array}{l}\text { Pensou em publicar na internet } \\
\text { desde o início? }\end{array}$ & $\begin{array}{l}\text { Sim, para receber feedback } \\
\text { imediato dos leitores. }\end{array}$ & $\begin{array}{l}\text { Sim, para outras pessoas } \\
\text { acompanharem, para ter } \\
\text { visibilidade. }\end{array}$ & $\begin{array}{l}\text { Sim, pela praticidade e visibilidade. } \\
\text { Se fosse para o impresso, seria ótimo, } \\
\text { mas não foi o objetivo inicial. }\end{array}$ & $\begin{array}{l}\text { Não, eu era muito insegura para } \\
\text { expor meu trabalho. }\end{array}$ \\
\hline $\begin{array}{l}\text { Possui publicação impressa? } \\
\text { Indique se foi por editora ou } \\
\text { independente. }\end{array}$ & $\begin{array}{l}\text { Sim. Bear (editora Nemo), } \\
\text { "Dora" e "Meu pai é um } \\
\text { homem da montanha" } \\
\text { (independentes) }\end{array}$ & $\begin{array}{l}\text { Sim. "Anna Bolenna - o } \\
\text { livro" (independente) }\end{array}$ & $\begin{array}{l}\text { Sim. "Mulheres" (editora Sextante) e } \\
\text { "Cores" (independente). }\end{array}$ & $\begin{array}{l}\text { Sim. "Navio Dragão", "Carne", } \\
\text { "Baleia \#1" e "Baleia \#2" } \\
\text { (independentes) }\end{array}$ \\
\hline $\begin{array}{l}\text { Quando começou a publicar } \\
\text { online? }\end{array}$ & Há 4 anos. & Há 3 anos. & Há 2 anos. & Há 3 anos. \\
\hline $\begin{array}{l}\text { Atualiza o site/blog/página } \\
\text { nas redes sociais com que } \\
\text { frequência? }\end{array}$ & $1 \mathrm{vez}$ por semana. & Mais de 1 vez por semana. & Diariamente. & $\begin{array}{l}\text { Não tenho regularidade de } \\
\text { publicação. }\end{array}$ \\
\hline
\end{tabular}




\begin{tabular}{|c|c|c|c|c|}
\hline Identificação da autora & $\begin{array}{l}\text { Bianca Pinheiro } \\
\text { (28 anos, Curitiba-PR) }\end{array}$ & $\begin{array}{l}\text { Amanda Reis } \\
\text { Assina: Bianka } \\
\text { ( } 23 \text { anos, Belo Horizonte } \\
\text { MG) }\end{array}$ & $\begin{array}{l}\text { Carolina Costa Rossetti } \\
\text { Assina: Carol Rosseti } \\
\text { (28 anos, Belo Horizonte MG) }\end{array}$ & $\begin{array}{l}\text { Rebeca Prado Santos Assina: } \\
\text { Rebeca Prado ( } 25 \text { anos, Brasília- } \\
\text { DF) }\end{array}$ \\
\hline $\begin{array}{l}\text { Costuma ler quadrinhos feitos } \\
\text { por mulheres? }\end{array}$ & $\begin{array}{l}\text { Sim. Emily Carroll, Noelle } \\
\text { Stevenson, Cris Eiko, } \\
\text { Samanta Flôor, Lu Caffagi, } \\
\text { Lila Cruz, entre muitas outras }\end{array}$ & $\begin{array}{l}\text { Sim. Quadrinhos nacionais } \\
\text { variados, Magra de Ruim, } \\
\text { Rebeca Prado, quadrinhos } \\
\text { das migas. }\end{array}$ & $\begin{array}{l}\text { Sim. Jill Thompson, Marjani Satrapi, } \\
\text { Mariko Tamaki, Rebeca Prado, Aline } \\
\text { Lemos, Ana Recalde, etc. }\end{array}$ & $\begin{array}{l}\text { Sim. Jill Thompson, ilegível, } \\
\text { Luchie, Bianca Pinheiro, ilegível, } \\
\text { etc. }\end{array}$ \\
\hline $\begin{array}{l}\text { Em geral, você enxerga } \\
\text { diferenças no modo como } \\
\text { personagens femininas são } \\
\text { representadas nas HQs feitas por } \\
\text { homens e mulheres? }\end{array}$ & $\begin{array}{l}\text { Varia de acordo com os(as) } \\
\text { quadrinistas. }\end{array}$ & $\begin{array}{l}\text { Sim. HQs masculinas } \\
\text { desenham mulheres de } \\
\text { maneira distorcida e, às } \\
\text { vezes, hipersexualizada. }\end{array}$ & Sim. & $\begin{array}{l}\text { Varia de acordo com os(as) } \\
\text { quadrinistas. }\end{array}$ \\
\hline
\end{tabular}

FONTE: A autora (2018) 
Quadro 4 - Entrevistas (continuação)

\begin{tabular}{|c|c|c|c|c|}
\hline Identificação da autora & $\begin{array}{l}\text { Renata Cristina Queiroz Rinaldi } \\
\text { Assina: Renata Rinadi } \\
\text { (28 anos, Brasília-DF) }\end{array}$ & $\begin{array}{l}\text { Taís Koshino } \\
(23 \text { anos, Brasília-DF) }\end{array}$ & $\begin{array}{l}\text { Fernanda Ferreira } \\
\text { Assina: Fernanda Nia } \\
\text { (26 anos, Rio de Janeiro-RJ) }\end{array}$ & $\begin{array}{l}\text { Thaiz Leão Gouveia } \\
\text { Assina: Thaiz Leão } \\
\text { (26 anos, São Paulo-SP) }\end{array}$ \\
\hline Publicação online & $\begin{array}{l}\text { "Mandíbula" } \\
\text { Link: } \\
\text { www.facebook.com/mandibulaquadrinhos }\end{array}$ & $\begin{array}{l}\text { "Vida difícil" } \\
\text { Link: } \\
\text { selopiqui.blogspot.com.br }\end{array}$ & $\begin{array}{l}\text { "Como eu realmente" } \\
\text { Link: } \\
\text { www.comoeurealmente.com }\end{array}$ & $\begin{array}{l}\text { "Mãe Solo" } \\
\text { Link: www.facebook.com/mamae- } \\
\text { solo }\end{array}$ \\
\hline $\begin{array}{l}\text { Pensou em publicar na } \\
\text { internet desde o início? }\end{array}$ & $\begin{array}{l}\text { Não, meu objetivo era ter visibilidade para } \\
\text { entrar no impresso posteriormente. }\end{array}$ & $\begin{array}{l}\text { Não, comecei sem pretensões e } \\
\text { pensei na internet como uma } \\
\text { forma de publicar sem custos. }\end{array}$ & e & $\begin{array}{l}\text { Sim, pela facilidade e falta de } \\
\text { pretensão. }\end{array}$ \\
\hline $\begin{array}{l}\text { Possui publicação } \\
\text { impressa? } \\
\text { Indique se foi por editora } \\
\text { ou independente. }\end{array}$ & $\begin{array}{l}\text { "Labirinto em linha reta", "O pequeno } \\
\text { Bapho" e "Last rose" }\end{array}$ & $\begin{array}{l}\text { Coral, O que tá dentro importa, } \\
\text { Topografias, entre outros } \\
\text { (independente) }\end{array}$ & $\begin{array}{l}\text { Como eu realmente } 1,2 \text { e } 3 \\
\text { (editora Nemo) }\end{array}$ & Chora lombar (independente) \\
\hline $\begin{array}{l}\text { Quando começou a } \\
\text { publicar online? }\end{array}$ & Há 3 anos. & Há 3 anos. & Há 5 anos. & Há 2 anos. \\
\hline $\begin{array}{l}\text { Atualiza o } \\
\text { site/blog/página nas } \\
\text { redes sociais com que } \\
\text { frequência? }\end{array}$ & Não tenho regularidade de publicação. & 1 vez por semana. & Mais de 1 vez por semana. & $\begin{array}{l}\text { Não tenho regularidade de } \\
\text { publicação. }\end{array}$ \\
\hline $\begin{array}{l}\text { Lê quadrinhos desde a } \\
\text { infância? Qual tipo? }\end{array}$ & Sim. Mangás e gibis nacionais. & Sim. Mangás e gibis nacionais. & Sim. Mangás e gibis nacionais. & $\begin{array}{l}\text { Sim. Mangás, zines e HQs } \\
\text { independentes e gibis internacionais. }\end{array}$ \\
\hline
\end{tabular}




\begin{tabular}{|c|c|c|c|c|}
\hline Identificação da autora & $\begin{array}{l}\text { Renata Cristina Queiroz Rinaldi } \\
\text { Assina: Renata Rinadi } \\
\text { (28 anos, Brasília-DF) }\end{array}$ & $\begin{array}{l}\text { Taís Koshino } \\
\text { (23 anos, Brasília-DF) }\end{array}$ & $\begin{array}{l}\text { Fernanda Ferreira } \\
\text { Assina: Fernanda Nia } \\
\text { (26 anos, Rio de Janeiro-RJ) }\end{array}$ & $\begin{array}{l}\text { Thaiz Leão Gouveia } \\
\text { Assina: Thaiz Leão } \\
\text { (26 anos, São Paulo-SP) }\end{array}$ \\
\hline $\begin{array}{l}\text { Qual(is) marcou(aram) } \\
\text { sua trajetória como } \\
\text { leitora? }\end{array}$ & Turma da Mônica, Tarzan, Clamp. & $\begin{array}{l}\text { Como uma luva de veluda } \\
\text { moldada em ferro (Daniel } \\
\text { Clowes), FunHome (Alison } \\
\text { Bechdel). }\end{array}$ & $\begin{array}{l}\text { Sakura Card Captors, Dragon } \\
\text { Ball, Magali. }\end{array}$ & $\begin{array}{l}\text { Moonshadows, Sandman, Watchmen, } \\
\text { Blade Samurai, Wimmen's Comix, } \\
\text { Zines e o que eu achasse de diferente } \\
\text { e estranho no sebo. }\end{array}$ \\
\hline $\begin{array}{l}\text { Costuma ler quadrinhos } \\
\text { feitos por mulheres? }\end{array}$ & Sim. Autoras nacionais. & $\begin{array}{l}\text { Sim. Puiupo, LoveLove6, } \\
\text { Anna Bolenna, Ingrid Kita, } \\
\text { Lila Cruz, Mazô, Thais } \\
\text { Gualberto. }\end{array}$ & $\begin{array}{l}\text { Sim. Tantas! Bianca Pinheiro, Lu } \\
\text { Caffagi, Aline Brosh, Carol } \\
\text { Rossetti, Mangakás.Etc. }\end{array}$ & $\begin{array}{l}\text { Thais Gualberto, LoveLove6. Não } \\
\text { sou boa com nomes, mas quando } \\
\text { adquiro, dou prioridade para o } \\
\text { consumo de publicações de mulheres. }\end{array}$ \\
\hline $\begin{array}{l}\text { Quando começou a ter } \\
\text { contato } \\
\text { com autoras mulheres? }\end{array}$ & Entre 20 e 25 anos. & Entre 20 e 25 anos. & Entre 10 e 15 anos (mangakás). & Entre 20 e 25 anos. \\
\hline $\begin{array}{l}\text { Em geral, você enxerga } \\
\text { diferenças no modo } \\
\text { como personagens } \\
\text { femininas são } \\
\text { representadas nas HQs } \\
\text { feitas por homens e } \\
\text { mulheres? }\end{array}$ & $\begin{array}{l}\text { Sim. Personalidade, constituição, } \\
\text { sexualização. }\end{array}$ & $\begin{array}{l}\text { Sim. Nas HQs feitas por } \\
\text { mulheres as personagens } \\
\text { femininas são } \\
\text { mais bem construídas. }\end{array}$ & $\begin{array}{l}\text { Sim. As mulheres feitas por } \\
\text { mulheres são mais complexas e } \\
\text { reais. }\end{array}$ & $\begin{array}{l}\text { Sim. Corpo, desejos, aspirações, } \\
\text { complexidade, emoção. }\end{array}$ \\
\hline
\end{tabular}

FONTE: A autora (2018) 


\section{APÊNDICE C - QUESTIONÁRIOS APLICADOS}

Questionários aplicados durante o Evento Lady’s Comics (2016) 


\section{QUESTIONÁRIO}

Desenvolvido como parte da pesquisa de Mestrado intitulada "Um panorama da produção feminina de quadrinhos publicados na internet no Brasil", do Programa de Pós-Graduação em Ciência da Informação, da Universidade de São Paulo (SP).

Mestranda: Carolina ito Messias

Orientadora: Giulia Crippa

Nome: BiANCA PinHEIRD

Idade: 28 aNOS Cidade/Estado: CURitiBA / PR

Publicąão online: http: /l bear - pt. tumblr. com

Formação: Artes GRÁfiCAS

Profissão: QUADRINisTA

Contato (email/telefone):_BCRISTALDi@GMAiL.Com

1) Você pensou em publicar na internet desde o início?

W $\operatorname{sim}$ - Qual motivo?

PRA RECEBER FEEDBACK IMEDIATO dOS LEITORES

( ) não, meu objetivo era ter visibilidade para entrar no impresso posteriormente

() não - Qual motivo?

2) Possui publicação impressa? Indique se foi por editora ou independente.
N) sim
- Qual? Bear (Nemo), "Dora "e "Mev poi é un homen da mantaha"
( ) não

(INDEPENDENTE)

3) Quando começou a publicar online?
() menos de 1 ano
() mais de um ano
(X) mais de 2 anos - Quantos anos? 4

4) Atualiza o site/blog/página nas redes sociais com que frequência?

X1 vez por semana

() mais de 1 vez por semana

( ) Não tenho regularidade de publicação

() Outro

5) Lê quadrinhos desde a infância?

Xsim

( ) não 
6) Qual tipo? Pode assinalar mais de uma opção.

( ) HQs de super-herois

W Mangás

(X) Zines / HQs independentes

(X) Gibis nacionais

(X) Gibis internacionais

() Outro -Qual(is)?

7) Qual(is) $H Q($ (s) marcou(aram) sua trajetória como leitora?

TODAS DA EMILY CARROLL, NIMONA, DA NDELLE STEVENSON, Tres SOMBras, do Cyril pEDrosa, Jimmy Corrigan, do CHR IS WARE

8) Costuma ler quadrinhos feitos por mulheres?

(x) $\operatorname{sim}$ - Quais autoras ou publicações?

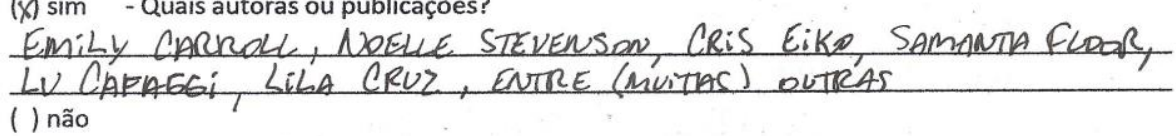

9) Quando começou a ter contato com autoras mulheres?

( ) entre 10 e 15 anos de idade

() entre 15 e 20 anos de idade

() entre 20 e 25 anos de idade

(X) entre 25 e 30 anes de idade

() mais de 30 anos de idade

10) Em geral, você enxerga diferenças no modo como personagens femininas são representadas nas HQs feitas por quadrinistas homens e mulheres?

() sim - Quais?

() não

(X) varia de acordo com os(as) quadrinistas

() outra justificativa - Qual?

\section{DECLARAÇÃO}

Eu, BIANCA PinttEIRO portadora do RG

71730260 e CPF $063267479-51$ declaro estar ciente de que esse questionário será utilizado com finalidade de pesquisa acadêmica.

Belo Horizonte, 3/ de julho de 2016.

Assinatura: fisan $\mathrm{OH}_{3} \mathrm{~h} / \mathrm{L}$ 


\section{QUESTIONÁRIO}

Desenvolvido como parte da pesquisa de Mestrado intitulada "Um panorama da produção feminina de quadrinhos publicados na internet no Brasil", do Programa de Pós-Graduação em Ciência da Informação, da Universidade de São Paulo (SP).

Mestranda: Carolina Ito Messias

Orientadora: Giulia Crippa

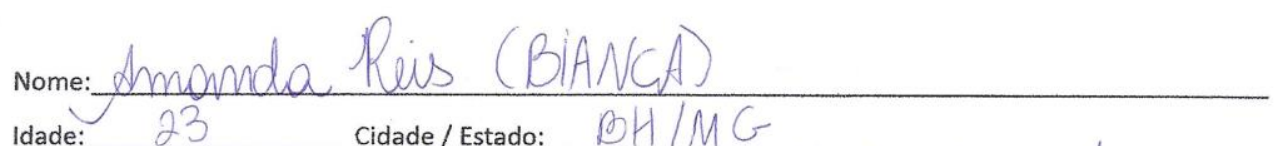

Publicação online: ANNA BOLE NNA- a pesturbada da conte

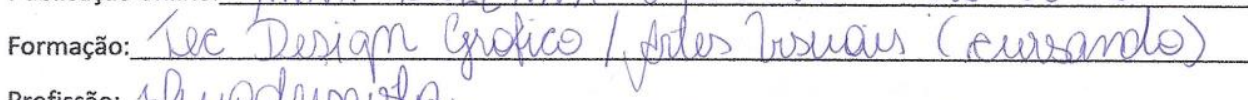
Profissão: Afupdunita

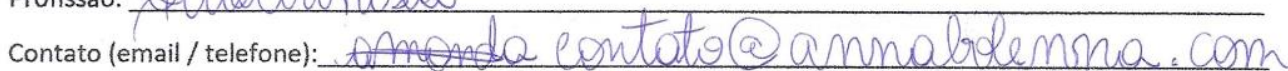

1) Você pensou em publicar na internet desde o início? (丈) $\operatorname{sim}$ - Qual motivo? Pana oubros pessoas acompamharem pera ter mishorluble

( ) não, meu objetivo era ter visibilidade para entrar no impresso posteriormente ( ) não - Qual motivo?

2) Possui publicação impressa? Indique se foi por editora ou independente,

(x) $\operatorname{sim}$

( ) não

- Qual?

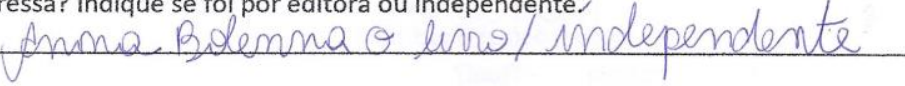

3) Quando começou a publicar online?
( ) menos de 1 ano
( ) mais de um ano
(x) mais de 2 anos - Quantos anos?

4) Atualiza o site/blog/página nas redes sociais com que frequência?
( ) 1 vez por semana
$\bigotimes$ mais de 1 vez por semana
() Não tenho regularidade de publicação
( ) Outro

5) Lê quadrinhos desde a infância?
( ) $\operatorname{sim}$
(Xnão imais ou memos) 
6) Qual tipo? Pode assinalar mais de uma opção.

() HQs de super-herois

( ) Mangás

( ) Zines / HQs independentes

(x) Gibis nacionais

() Gibis internacionais

() Outro - Qual(is)?

7) Qual(is) HQ(s) marcou(aram) sua trajetória como leitora? toola mafalda

8) Costuma ler quadrinhos feitos por mulheres?

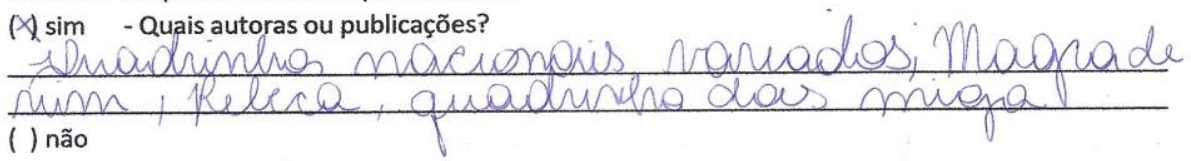

9) Quando começou a ter contato com autoras mulheres?
( ) entre 10 e 15 anos de idade
(4) entre 15 e 20 anos de idade
$凶$ entre 20 e 25 anos de idade
() entre 25 e 30 anos de idade
( ) mais de 30 anos de idade

10) Em geral, você enxerga diferenças no modo como personagens femininas são representadas nas HQs feitas por quadrinistas homens e mulheres?

(x) sim - Quais? HQ mosculinas desentown mulheres de () não monura desloncida e as renes puperseduali.

( ) varia de acordo com os(as) quadrinistas quola
( ) outra justificativa - Qual?

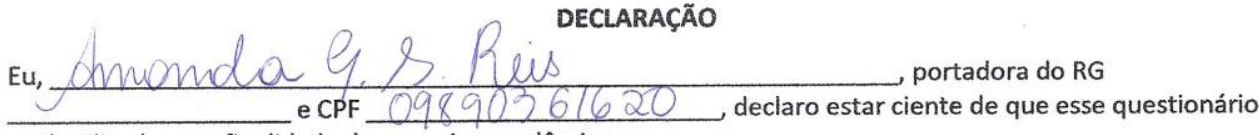
será utilizado com finalidade de pesquisa acadêmica.

Belo Horizonte, 31 de julho de 2016.

Assinatura: 


\section{QUESTIONÁRIO}

Desenvolvido como parte da pesquisa de Mestrado intitulada "Um panorama da produção feminina de quadrinhos publicados na internet no Brasil", do Programa de Pós-Graduação em Ciência da Informação, da Universidade de São Paulo (SP).

Mestranda: Carolina Ito Messias

Orientadora: Giulia Crippa

Nome:Cardina Costa Rosetti (Conol Rossetti)

Idade: 28 Cidade / Estado: BH/MG

Publicação online: Mulheres, Cores, Cartilha "Vamos Conversar?"

Formação: designer qráfico

Profissão: designer, ilustra olore, quadrimista

contato (email / telefone): carolrossettidesign@gmail.com/3199303.1929

1) Você pensou em publicar na internet desde o início?

Asim - Qual motivo?

Pela praticidade visibilidade. Se posse para o impresso, serio

ófimo, mas näo loi o olejetivo imicial.

( ) não, meu objetivo era ter visibilidade para entrar no impresso posteriormente

( ) não - Qual motivo?

2) Possui publicação impressa? Indique se foi por editora ou independente.

(X) sim -Qual? Mulheres - Editora Sextante (2015)

(1) não Cores - independente (será cancado nov/2016)

3) Quando começou a publicar online?

() menos de 1 ano

( ) mais de um ano

W. mais de 2 anos - Quantos anos? 2 anos e meio

4) Atualiza o śite/blog/página nas redes sociais com que frequência?

( ) 1 vez por semana

$(x)$ mais de 1 vez por semana - diariamente

( ) Não tenho regularidade de publicação

() Outro

5) Lê quadrinhos desde a infância?

$x / \operatorname{sim}$

( ) não 
6) Qual tipo? Pode assinalar mais de uma opção.
() HQs de super-herois
() Mangás
( ) Zines / HQs independentes
$\$$ Gibis nacionais
X Gibis internacionais
( ) Outro -Qual(is)?

7) Qual(is) $H Q$ (s) marcou(aram) sua trajetória como leitora?

Turma da Mônica na infância, Sandman na
adolescêncic.

8) Costuma ler quadrinhos feitos por mulheres?
$\mathcal{A} \operatorname{sim}$-Quais autoras ou publicações? Lill Thempson, Marjani Satrapi, Mariko Tamaki,
Rebece Prodo, Aline hemos, Ana Recalde, ete.
() não

9) Quando começou a ter contato com autoras mulheres?

() entre 10 e 15 anos de idade

Xentre 15 e 20 anos de idade

( ) entre 20 e 25 anos de idade

() entre 25 e 30 anos de idade

( ) mais de 30 anos de idade

10) Em geral, você enxerga diferenças no modo como personagens femininas são representadas nas HOs feitas por quadrinistas homens e mulheres?

Wim - Quais?
() não
( ) varia de acordo com os(as) quadrinistas
() outra justificativa - Qual?

\section{DECLARAÇÃO}

Eu, Carolina Costa Possetti

MG12025.368 e CPF $016 \quad 766 \quad 126$ - 45 , declaro estar ciente de que esse questionário será utilizado com finalidade de pesquisa acadêmica.

Belo Horizonte, 31 de julho de 2016.

Assinatura:

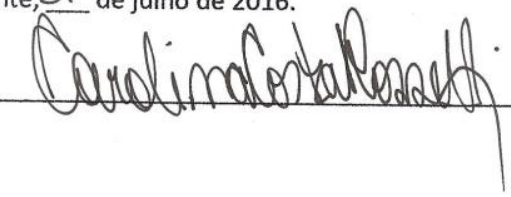


QUESTIONÁRIO

Desenvolvido como parte da pesquisa de Mestrado intitulada "Um panorama da produção feminina de quadrinhos publicados na internet no Brasil", do Programa de Pós-Graduação em Ciência da Informação, da Universidade de São Paulo (SP).

Mestranda: Carolina Ito Messias

Orientadora: Giulia Crippa

Nome: Releca Rrado Dan tos

Idade: 25 cidade / Estado: BH - MG

Publicação online:Ballia / havio verogāo

Formação: Ltetos viouais/linema de Animacĩos

Profissão: Llustrodora-Quodrinista-Profesoora

Contato (email/ telefone): (31)97187-8099 - increbeca@ gmail.com

1) Você pensou em publicar na internet desde o início?

() $\operatorname{sim} \quad$ - Qual motivo?

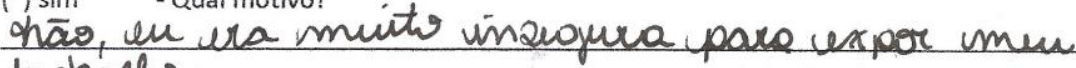

trobacho.

( ) não, meu objetivo era ter visibilidade para entrar no impresso posteriormente

(X) não - Qual motivo?

2) Possui publicação impressa? Indique se foi por editora ou independente.

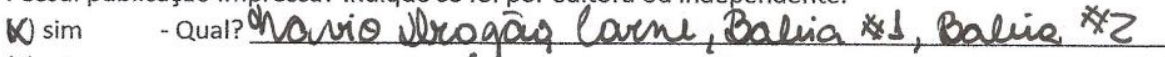

() não

- Independentes -

3) Quando começou a publicar online?
() menos de 1 ano
() mais de um ano
M mais de 2 anos - Quantos anos?
3

4) Atualiza o site/blog/página nas redes sociais com que frequência?
( ) 1 vez por semana
( ) mais de 1 vez por semana
(\) Não tenho regularidade de publicação
( ) Outro

5) Lê quadrinhos desde a infância?

(4) $\operatorname{sim}$

( ) não 
6) Qual tipo? Pode assinalar mais de uma opção. (D) HQs de super-herois

A) Mangás

( ) Zines / HQs independentes

A Gibis nacionais

() Gibis internacionais

( ) Outro - Qual(is)?

7) Qual(is) $H Q(s)$ marcou(aram) sua trajetória como leitora?
Retalhop/leaig Thompaon) Oe fontaoma de Anya (Veo
Broggol)

8) Costuma ler quadrinhos feitos por mulheres?

(Mill Jhompoon, Verabee, Luchie, Bianca Rinhiro,
Bebo Tare, WAC. () não

9) Quando começou a ter contato com autoras mulheres?

() entre 10 e 15 anos de idade

() entre 15 e 20 anos de idade

Mentre 20 e 25 anos de idade

() entre 25 e 30 anos de idade

( ) mais de 30 anos de idade

10) Em geral, você enxerga diferenças no modo como personagens femininas são representadas nas HQs feitas por quadrinistas homens e mulheres?

() $\operatorname{sim}$ - Quais?

() não

M) varia de acordo com os(as) quadrinistas

() outra justificativa - Qual?

\section{DECLARAÇÃo}

Eu, Rebeca Prodo Wantos , portadora do RG

M 616.466 .312 e CPF $017.695 .726-a_{2}$, declaro estar ciente de que esse questionário será utilizado com finalidade de pesquisa acadêmica.

Belo Horizonte, 31 de julho de 2016.

Assinatura: Rulece Prado Wantos. 


\section{QUESTIONÁRIO}

Desenvolvido como parte da pesquisa de Mestrado intitulada "Um panorama da produção feminina de quadrinhos publicados na internet no Brasil", do Programa de Pós-Graduação em Ciência da Informação, da Universidade de São Paulo (SP).

Mestranda: Carolina Ito Messias

Orientadora: Giulia Crippa

Nome: ReNaTA CRISTINA QUETROZ RINALDI

Idade: 28 Cidade / Estado: BRASiLiA / DF

Publicação online: MANDIBULA. Qu anRRiNutos

Formação: ARtES PLÁSTICAS

Profissão: ILUSTRACORA / ARTISTA

Contato (email / telefone): RiNALDI. RE@ gmiL.COM

1) Você pensou em publicar na internet desde o início?

() $\operatorname{sim}$-Qual motivo?

não, meu objetivo era ter visibilidade para entrar no impresso posteriormente

() não - Qual motivo?

2) Possui publicação impressa? Indique se foi por editora ou independente.

(6) $\operatorname{sim}$ - Qual? LABIRINIOEM LINGA RETA, O PEEQUENO BAPAO, LASTRESA

( ) não

3) Quando começou a publicar online?
() menos de 1 ano
() mais de um ano
18 mais de 2 anos - Quantos anos? 2013

4) Atualiza o site/blog/página nas redes sociais com que frequência?
() 1 vez por semana
() mais de 1 vez por semana
( ) Não tenho regularidade de publicação
$\otimes$ Outro

5) Lê quadrinhos desde a infância?

(ख) sim

( ) não 
6) Qual tipo? Pode assinalar mais de uma opção.

( ) HQs de super-herois

$\otimes$ Mangás

( ) Zines / HQs independentes

(v) Gibis nacionais

() Gibis internacionais

( ) Outro - Qual(is)?

7) Qual(is) $H Q(s)$ marcou(aram) sua trajetória como leitora?

\section{IURMA M MÓNICA, TARZAN, CLAMP,}

8) Costuma ler quadrinhos feitos por mulheres?

(૪) $\operatorname{sim}$ - Quais autoras ou publicações?

cuterts nolend's:

( ) não

9) Quando começou a ter contato com autoras mulheres?

( ) entre 10 e 15 anos de idade

() entre 15 e 20 anos de idade

$\bigotimes$ entre 20 e 25 anos de idade

() entre 25 e 30 anos de idade

( ) mais de 30 anos de idade

10) Em geral, você enxerga diferenças no modo como personagens femininas são representadas nas HQs feitas por quadrinistas homens e mulheres?

$\Delta \operatorname{sim}$ - Quais? PER SONALIMAR, GOSTITH CONSTituicio, SEYUALifacio

( ) não

( ) varia de acordo com os(as) quadrinistas

( ) outra justificativa - Qual?

Eu, Renate Cisitine of. Rimales:

DECLARAÇÃO

14.608 .656 e CPF Orc 18022862

será utilizado com finalidade de pesquisa acadêmica.

portadora do RG

declaro estar ciente de que esse questionário

Belo Horizonte, 81 de julho de 2016.

Assinatura: Renctarkmealdi 


\section{QUESTIONÁRIO}

Desenvolvido como parte da pesquisa de Mestrado intitulada "Um panorama da produção feminina de quadrinhos publicados na internet no Brasil", do Programa de Pós-Graduação em Ciência da Informação, da Universidade de São Paulo (SP).

Mestranda: Carolina Ito Messias

Orientadora: Giulia Crippa

Nome: Tais Koshino

23 Cidade / Estado: Brasília / DF

Publicação online: Vida difici

Formação: Superior completo: Comunicagẽo Secial

Profissão: Animadora e auadrinista

Contato (email / telefone): tais Koshino @ 6 mail. com

1) Você pensou em publicar na internet desde o início?

( ) $\operatorname{sim}$

- Qual motivo?

() não, meu objetivo era ter visibilidade para entrar no impresso posteriormente

(X) não - Qual motivo?

comecei sem pretensöes e pensei na internet come uma forma de publioar sem custos

2) Possui publicação impressa? Indique se foi por editora ou independente.
( ) $\operatorname{sim}$
Qual?
(X) não desse quadrinh

3) Quando começou a publicar online?
(1) menos de 1 ano
( ) mais de um ano
( 1 mais de 2 anos - Quantos anos?

4) Atualiza o site/blog/página nas redes sociais com que frequência?
(x) 1 vez por semana (a tualmente)
( ) mais de 1 vez por semana
( ) Não tenho regularidade de publicação

( ) Outro

5) Lê quadrinhos desde a infância?
(X) sim
() não 
6) Qual tipo? Pode assinalar mais de uma opção.

() HQs de super-herois

(X) Mangás

( ) Zines / HQs independentes

(x) Gibis nacionais

() Gibis internacionais

() Outro - Qual(is)?

7) Qual(is) HQ(s) marcou(aram) sua trajetória como leitora?

Como uma luva de veludo moldada en pecro, Daniel Clowes Funhome

8) Costuma ler quadrinhos feitos por mulheres?

(x) $\operatorname{sim}$ - Quais autoras ou publicações?

Puiver, Levelove 6, Anna Bolena, Ingrid Kita, Lila Cruz, Mazó, Theris Gualberto

( ) não

9) Quando começou a ter contato com autoras mulheres?

( ) entre 10 e 15 anos de idade

() entre 15 e 20 anos de idade

(X) entre 20 e 25 anos de idade

( ) entre 25 e 30 anos de idade

() mais de 30 anos de idade

10) Em geral, você enxerga diferenças no modo como personagens femininas são representadas nas HQs feitas por quadrinistas homens e mulheres?

(x) $\operatorname{sim}$-Quais? Säa persona

( ) não

() varia de acordo com os(as) quadrinistas

() outra justificativa - Qual?

Nas HQs feitas por mulheres as personagens femininas säj mais bem construidas.

\section{DECLARAÇÃO}

Eu, Tais Fernandes Koshino portadora do RG

2761472 S2P/DF e CPF $017037891-80$ será utilizado com finalidade de pesquisa acadêmica. declaro estar ciente de que esse questionário

Belo Horizonte, 31 de julho de 2016.

Assinatura: Tais koshino 


\section{QUESTIONÁRIO}

Desenvolvido como parte da pesquisa de Mestrado intitulada “Um panorama da produção feminina de quadrinhos publicados na internet no Brasil”, do Programa de Pós-Graduação em Ciência da Informação, da Universidade de São Paulo (SP).

\section{Mestranda: Carolina Ito Messias}

Orientadora: Giulia Crippa

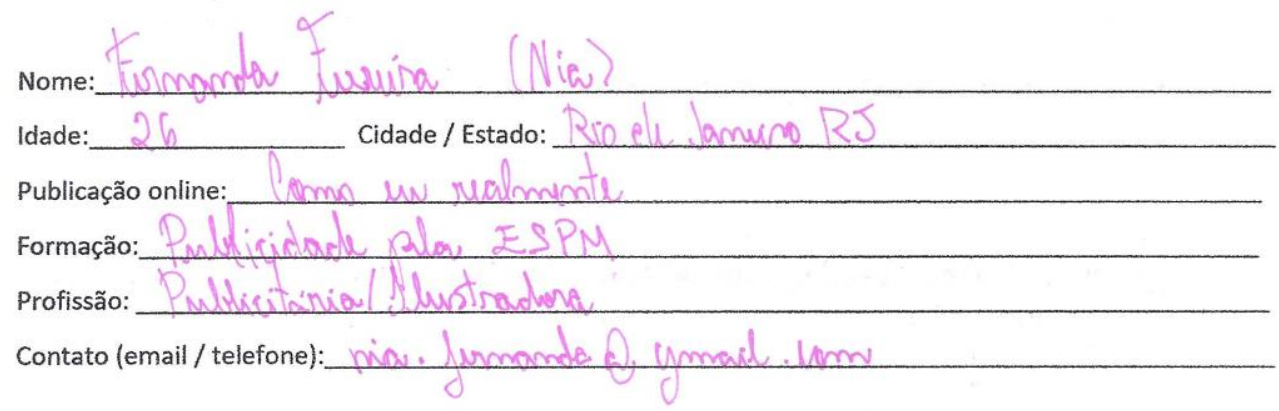

1) Você pensou em publicar na internet desde o início? () $\operatorname{sim}$ - Qual motivo?

Tacilidade/Gǖo

( ) não, meu objetivo era ter visibilidade para entrar no impresso posteriormente

( ) não -Qual motivo?

2) Possui publicação impressa? Indique se foi por editora ou independente.

()) $\operatorname{sim}$

- Qual?

( ) não

3) Quando começou a publicar online?
() menos de 1 ano
() mais de um ano
(y) mais de 2 anos - Quantos anos?

4) Atualiza o site/blog/página nas redes sociais com que frequência?
( ) 1 vez por semana
(M) mais de 1 vez por semana
( ) Não tenho regularidade de publicação

() Outro

5) Lê quadrinhos desde a infância?
(1).sim

( ) não 
6) Qual tipo? Pode assinalar mais de uma opção.

( ) HQs de super-herois

(M) Mangás

() Zines / HQs independentes

A Gibis nacionais

( ) Gibis internacionais

() Outro - Qual(is)?

7) Qual(is) $\mathrm{HQ}(\mathrm{s})$ marcou(aram) sua trajetória como leitora?

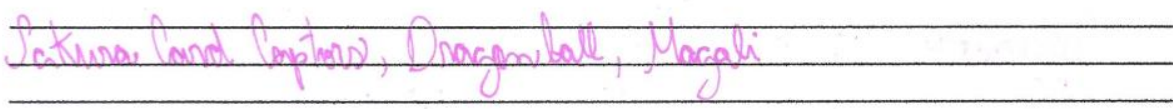

8) Costuma ler quadrinhos feitos por mulheres?

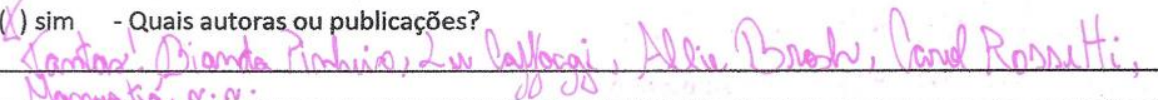

() não

9) Quando começou a ter contato com autoras mulheres?

(4) entre 10 e 15 anos de idade

() entre 15 e 20 anos de idade

4 mangakós

() entre 20 e 25 anos de idade

() entre 25 e 30 anos de idade

() mais de 30 anos de idade

10) Em geral, você enxerga diferenças no modo como personagens femininas são representadas nas HQs feitas por quadrinistas homens e mulheres?
(1) $\operatorname{sim}$ - Quais?
( ) não
( ) varia de acordo com os(as) quadrinistas
( ) outra justificativa - Qual?

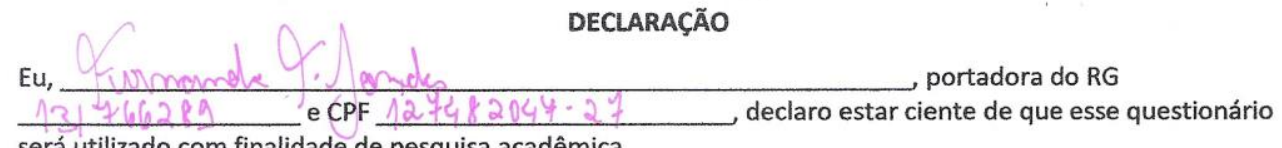
será utilizado com finalidade de pesquisa acadêmica.

Belo Horizonte, 29 de julho de 2016.

Assinatura:

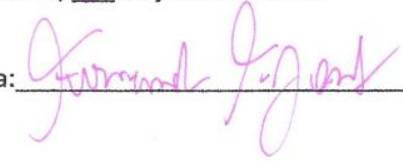




\section{QUESTIONÁRIO}

Desenvolvido como parte da pesquisa de Mestrado intitulada "Um panorama da produção feminina de quadrinhos publicados na internet no Brasil", do Programa de Pós-Graduação em Ciência da Informação, da Universidade de São Paulo (SP).

Mestranda: Carolina Ito Messias

Orientadora: Giulia Crippa

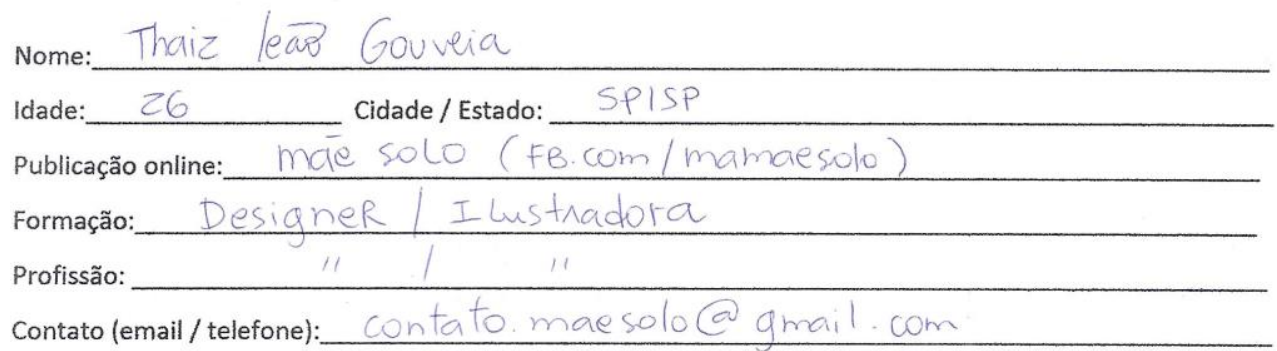

1) Você pensou em publicar na internet desde o início? (x) $\operatorname{sim}$-Qual motivo? Facilidade e Palta de pretencao

( ) não, meu objetivo era ter visibilidade para entrar no impresso posteriormente ( ) não - Qual motivo?

2) Possui publicação impressa? Indique se foi por editora ou independente.

( ) $\operatorname{sim}$

- Qual?

() não

3) Quando começou a publicar online?

( ) menos de 1 ano

( ) mais de um ano

(4) mais de 2 anos - Quantos anos?

4) Atualiza o site/blog/página nas redes sociais com que frequência?

( ) 1 vez por semana

( ) mais de 1 vez por semana

(X) Não tenho regularidade de publicação

( ) Outro

5) Lê quadrinhos desde a infância?

甘sim

( ) não 
6) Qual tipo? Pode assinalar mais de uma opção.

() HQs de super-herois

A Mangás

A Zines / HQs independentes

() Gibis nacionais

Q Gibis internacionais

() Outro - Qual(is)?

7) Qual(is) $\mathrm{HQ(s)} \mathrm{marcou(aram)} \mathrm{sua} \mathrm{trajetória} \mathrm{como} \mathrm{leitora?}$

MoONSHadows Sandmana MORte WATCHmen, Blade Samura, wimens comix, zines, e o que mais en achasse de diferente z estanho no sebo.

8) Costuma ler quadrinhos feitos por mulheres?

Nim - Quais autoras ou publicações?

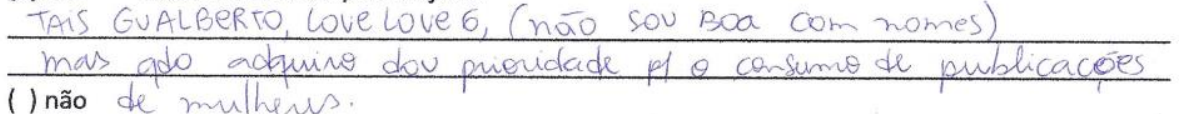

9) Quando começou a ter contato com autoras mulheres?

() entre 10 e 15 anos de idade

( ) entre 15 e 20 anos de idade

Yentre 20 e 25 anos de idade

() entre 25 e 30 anos de idade

() mais de 30 anos de idade

10) Em geral, você enxerga diferenças no modo como personagens femininas são representadas nas HQs feitas por quadrinistas homens e mulheres?

(A) sim - Quais? conpo, de sejos, aspinacés, complexidade, emocao

( ) não

() varia de acordo com os(as) quadrinistas

() outra justificativa - Qual?

\section{DECLARAÇÃO}

Eu, Thaiz leaD Gouveia portadora do RG

46.903.193-1 e CPF $394.683908-88$ declaro estar ciente de que esse questionário será utilizado com finalidade de pesquisa acadêmica.

Belo Horizonte, 31 de julho de 2016.

Assinatura:

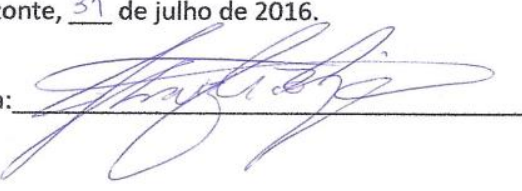




\section{APÊNDICE D - EDITORAS E PUBLICAÇÕES}

Títulos publicados por editora pesquisadas

\section{BARRICADA}

Barricada é um selo de quadrinhos lançado pela Boitempo em julho de 2014. O selo reúne histórias em quadrinhos nacionais e internacionais garimpadas por um conselho editorial que conta com especialistas como Luiz Gê, Ronaldo Bressane e Gilberto Maringoni, entre outros. Como o próprio nome sugere, o selo se dedica a títulos libertários, de resistência, que se destacam inovando o cenário independente de quadrinhos. 7

7 títulos / 3 mulheres

- Laerte - Modelo Vivo ARTES GRÁFICAS

- Último Aviso - Franziska Becker VIDA PRIVADA / SOCIAL / FEMINISMO

- Marx: uma biografia em quadrinhos - Anne Simon e Corine Maier BIOGRAFIA / POLÍTICA

\section{VENETA}

Essa editora tem como responsabilidade social desafiar convenções, os consensos manufaturados, as autoridades em geral e, se necessário, seus leitores.

58 títulos / 11 de mulheres /

- Afrodite: quadrinhos eróticos - Alice Ruiz e Paulo Leminski EROTISMO

- Carolina - Sirlene Barbosa e João Pinheiro BIOGRAFIA / SOCIAL

- Estudante de medicina - Cynthia B. AUTOBIOGRAFIA

- Quem tá chorando - Allan Sieber e Claudia Jouvin FAMÍLIA / AUTOBIOGRÁFICO

- Coração das trevas - Catherine Anyango, David Zane Mairowitz, Joseph Conrad FICÇÃO / AVENTURA

- Gabo - Felipe Camargo, Julián Naranjo, Miguel Bustos, Óscar Pantoja, Tatiana Córdoba BIOGRAFIA

- Ghetto Brohter - Claudia Ahlering, Julian Voloj HISTÓRIA / HIP HOP 
- Giovaníssima - Giovanna Casotto EROTISMO

O processo - Chantal Montellier, David Zane Mairowitz ADAPTAÇÃO LITERÁRIA

Baderna - 68: como incendiar um país - Erick Corrêa, Maria Teresa Mhereb HISTÓRIA / POLÍTICA

Sorge - o espião - Isabel Kreitz HISTÓRIA / POLÍTICA

\section{NEMO [grupo autêntica]}

O Grupo Editorial Autêntica partiu, em 2011, para uma grande empreitada: os quadrinhos. E para abarcar as obras dessa fascinante forma de arte, a Editora Nemo foi criada.

A proposta inicial da Nemo era reunir nomes mundialmente reconhecidos das HQs e autores brasileiros contemporâneos, valorizando essa linguagem artística repleta de preciosidades. Entre os autores que compõem o catálogo da editora estão os consagrados Jean Giraud, francês conhecido internacionalmente pelo pseudônimo Moebius, o italiano Hugo Pratt, criador do clássico personagem Corto Maltese, o francês Jacques Tardi, autor de brilhantes HQs históricas, o genial Enki Bilal e o surpreendente Frederik Peeters. O catálogo é também composto por vários talentos dos quadrinhos nacionais, como Flavio Colin, Will, Lillo Parra, José Aguiar, entre outros. O time de autoras nacionais da Nemo conta com as premiadas quadrinistas Lu Cafaggi, Bianca Pinheiro, Fernanda Nia, Fefê Torquato e roteiros da best-seller Paula Pimenta.

Cumprindo com brilhantismo sua proposta inicial, a editora viu a necessidade de trazer também a publicação de graphic novels com temáticas de relevância, como questão de gênero, abuso sexual, misoginia e responsabilidade social para o Brasil. Céline Fraipont, Pierre Bailly, Ugo Bertotti, Mana Neyestani, Power Paola, Margaux Motin, Pénélope Bagieu, Julia Wertz e muitos outros incorporam o time de autores que prometem romances gráficos instigantes e inesquecíveis. Com a proposta de combater o preconceito existente no segmento, a editora agora aposta em publicações de autoria feminina para mostrar que, mais do que nunca, as mulheres têm produzido quadrinhos de qualidade no mundo todo.

140 títulos / 41 de mulheres

35 nacionais / 14 de mulheres

- Justin - Gauthier GÊNERO

- Os diários de Amora - Joris Chamblain, Aurélie Neyret FICÇÃO / AVENTURA 
- O melhor que podíamos fazer - Thi Bui AUTOBIOGRAFIA

- Turma da monica jovem - contos: uma viagem inesperada - Babi Dewet, Melina Souza, Carol Christo, Pam Gonçalves (autoria), Mauricio de Sousa FICÇÃO / AVENTURA

- A diferença invisível - Mademoiselle Caroline, Julie Dachez SAÚDE MENTAL

- O diário de Anne Frank em quadrinhos - Anne Frank, Mirella Spinelli HISTÓRIA / BIOGRAFIA

- Deslocamento: um diário de viagem - Lucy Knisley (autoria), Carol Christo (tradução) AUTOBIOGRAFIA

- Desconstruindo Una - Una GÊNERO / AUTOBIOGRAFIA

- O último mestre Pokémon - Carol Christo FICÇÃO / AVENTURA

- O enterro das minhas ex - Gauthier GÊNERO / RELACIONAMENTOS

- *Bear - Bianca Pinheiro FICÇÃO / AVENTURA

- O mundo de dentro - Bruna Vieira e Lu Caffagi AUTOBIOGRAFIA

- *Fazendo o meu filme - Paula Pimenta SÉRIE / AVENTURA

- Entre umas e outras - Julia Wertz AUTOBIOGRAFIA

- *O chamado do oceano - Nancy Osa SÉRIE INFANTIL / MINECRAFT / FICÇÃO

- Uma morte horrível - Pénélope Bagieu FICÇÃO / RELACIONAMENTO

- Placas tectônicas - Margaux Motin AUTOBIOGRAFIA

- *Ponto de origem - Nancy Osa SÉRIE INFANTIL / MINECRAFT / FICÇÃO

- *Exílio nas terras distantes - Nancy Osa SÉRIE INFANTIL / MINECRAFT / FICÇÃO

- *A batalha da colina Zumbi - Nancy Osa SÉRIE INFANTIL / MINECRAFT / FICÇÃO

- *Rick bloco e a ameaça da peça Onix - Tamony Hall SÉRIE INFANTIL / MINECRAFT / FICÇÃO

- Quando tudo começou - Bruna Vieira e Lu Cafaggi AUTOBIOGRAFIA

- *Fazendo o meu filme 2 - Paula Pimenta SÉRIE / AVENTURA

- Vírus tropical - Power Paola AUTOBIOGRAFIA

- Primeiras vezes - Sibylline EROTISMO / SEXO / GÊNERO

- *Como eu realmente - Fernanda Nia FICÇÃO / HUMOR 
- O muro - Céline Fraipont, Pierre Bailly HISTÓRIA

- *Bear Vol 2 - Bianca Pinheiro FICÇÃO / AVENTURA

- Gata Garota - Fefê Torquato FICÇÃO

- *Bear vol 1 - Bianca Pinheiro FICÇÃO / AVENTURA

- *Como eu realmente - vol 1 FICÇÃO / HUMOR

- Leonardo da Vinci - Mirella Spinelli BIOGRAFIA

- *Fazendo meu filme - Paula Pimenta SÉRIE / AVENTURA

- As crianças da sombra - Béka [É o pseudônimo da dupla francesa integrada por Bertrand Escaich e Caroline Roque] FICÇÃO / AVENTURA

- A narradora das neves - Béka FICÇÃO / AVENTURA

- O apanhador de nuvens - Béka FICÇÃO / AVENTURA

- Macbeth - Marcela Godoy ADAPTAÇÃO LITERÁRIA

- Romeu e Julieta - Marcela Godoy ADAPTAÇÃO LITERÁRIA

\section{MINO}

A Editora Mino surgiu no espaço editorial brasileiro em 2014, com a proposta de publicar quadrinhos autorais que tenham em comum uma personalidade marcante. Sabendo que a arte sequencial é um campo fértil para criar mundos e invadir cabeças, a Mino fincou sua bandeira no território do quadrinho nacional: já são mais de 40 livros editados e agrupados num catálogo que reúne a nata do quadrinho nacional e internacional em edições extremamente cuidadosas.

36 títulos / 2 de mulheres

Dora - Bianca Pinheiro FICÇÃO / AVENTURA

Cais - Janaina de Lula e Pedro Cobiaco FICÇÃO / AVENTURA

\section{QUADRINHOS NA CIA}

- 112 títulos / 16 de mulheres

- Desenhados um para o outro - Aline Crumb e Robert Crumb AUTOBIOGRAFIA

- As barbas do imperador - Lilia Moritz Schwarcz e Spacca HISTÓRIA 
- Você é minha mãe - Alison Bechdel AUTOBIOGRAFIA

- A máquina de Goldberg - Vanessa Barbara e Fido Nesti FICÇÃO

- Freud - Anne Simon e Corinne Maier BIOGRAFIA

- Adeus Tristeza - Belle Yang AUTOBIOGRAFIA

- Muchacha - Laerte (2010) FICÇÃO

- Bordados - Marjane Satrapi AUTOBIOGRAFIA / GÊNERO

- Frango com ameixas - Marjani Satrapi AUTOBIOGRAFIA

- Persépolis - Marjani Satrapi AUTOBIOGRAFIA

- D. João Carioca - Lilia Moritz Schwarcz e Spacca HISTÓRIA

- Persépolis 4 - Marjane Satrapi AUTOBIOGRAFIA

- Persépolis 3 - Marjane Satrapi AUTOBIOGRAFIA

- Persépolis 2 - Marjane Satrapi AUTOBIOGRAFIA

- Persépolis 1 - Marjane Satrapi AUTOBIOGRAFIA

- Little Lit - Art Spiegelman e Françoise Mouly FICÇÃO

\section{LOTE 42}

Fundada no final de 2012, a Lote 42 é uma editora sem preconceitos quanto a suportes. Para a empresa, um livro é ao mesmo tempo de papel e digital. Cada obra com o selo Lote 42 dialoga com as redes à sua maneira. Um livro da marca não se esgota na última palavra. O texto de cada livro se desdobra e invade redes sociais, site da editora, entre outras produções do autor.

Nesse sentido, a Lote 42 age como uma amplificadora do debate gerado pelo livro. Apostamos no leitor. É ele quem determina o caminho a ser seguido para a obra crescer - seja solicitando a realização de uma conversa por e-mail com outras pessoas que também desfrutaram da obra ou até mesmo em videoconferência com os escritores.

A Lote 42 entende a web como uma poderosa aliada para disseminar a cultura, respeitando os preceitos dos bons livros impressos.

Acreditamos que o leitor é quem deve decidir a melhor maneira de aproveitar sua leitura. Os assuntos que nos comprometemos em apresentar ao público atenderão demandas contemporâneas da sociedade, mas sem deixar de lado um tratamento cuidadoso, sempre sustentado pela tese de que o texto precisa ir além do tempo real.

A Lote 42 responde às demandas de um público que cada vez mais exige qualidade de reflexão. A Lote 42 tem como propósito editorial pensar a sociedade em que vivemos, 
demarcar e estender nossos papéis sociais e políticos, transformar o estado passivo da matéria que insiste em inércia, proporcionar o acesso à reflexão e à imaginação.

- O pintinho - Alexandra Moraes

- O pintinho 2 - Alexandra Moraes 